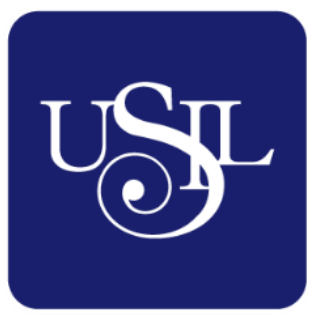

UNIVERSIDAD

SAN IGNACIO

DE LOYOLA

ESCUELA DE POSTGRADO

Maestría en Diseño Gráfico

\title{
EL VIDEO INTERACTIVO COMO HERRAMIENTA EDUCATIVA PARA PROMOVER EL CUMPLIMIENTO DEL REGLAMENTO DE TRÁNSITO Y PROPICIAR LA NO VIOLENCIA VIAL
}

Tesis para optar al grado de Maestro en Diseño Gráfico

ENRIQUE MAURICIO JESUS VARGAS VIVANCO

Asesor:

Mg. Rafael Ernesto Vivanco Alvarez

Lima - Perú

2020 


\section{Resumen}

La siguiente investigación se realiza con el fin de dar a conocer cómo el caos vehicular y el no cumplimiento y respeto por las reglas básicas de tránsito hacen que las personas adopten actitudes agresivas que llegan a desencadenar en una violencia vial frente a los demás conductores debido al alto nivel de imprudencia al manejar. El estudio realizado evidencia que faltas básicas al reglamento de tránsito, entre ellas pararse en medio de la calzada en doble fila, doblar a la izquierda cuando no está permitido y parar a recoger pasajeros en una calle de doble vía hacen que el tráfico se congestione, ocasionando una pérdida de tiempo innecesaria y, por ende, aumentando el estrés en los demás conductores, llegando a desencadenar insultos y peleas; más conocido como violencia vial. El objetivo del proyecto consistió en realizar una campaña de concientización enfocada en jóvenes que ya cuenten con licencia para conducir o estén próximos a tenerla, para así poder educar sobre la importancia del cumplimiento del reglamento de tránsito y seguridad vial, evitando por tanto la violencia vial. Por ello el diseño gráfico llevado a una plataforma de video educativo utilizando la técnica de "stop-motion" utilizando piezas de Lego resulta efectivo para captar el interés de los jóvenes estimulando una actitud de cambio sobre lo importante que es conocer y respetar las reglas de tránsito para evitar generar más caos en las pistas y con ello disminuir el estrés y así combatir la violencia vial.

Palabras clave: diseño, violencia vial, stop motion, video educativo 


\section{Abstract}

The following investigation was carried out in order to raise awareness on how vehicular chaos and the lack of respect for basic traffic rules causes people to adopt aggressive attitudes that lead to road violence in front of other drivers due to the high levels of reckless driving. The study makes evidence that basic violations of the traffic regulations, including standing in the middle of a double-lane street, turning left when not allowed and stopping to pick up passengers on a two-way street cause traffic to become congested, causing an unnecessary waste of time and therefore increasing stress on other drivers, making them scream, insult and in some cases physical violence; all of this is known as road violence. The objective of the project is to conduct an awareness campaign focused on young people who already have a driver's license or are close to having it, in order to educate them about the importance of compliance with traffic regulations and road safety, reducing the levels of road violence. For this reason, graphic design brought to an educational video platform using the "stop-motion" technique using Lego pieces is effective in capturing the interest of young people by stimulating an attitude of change regarding the importance of knowing and respecting the rules of traffic to avoid creating more chaos on the streets and thereby reduce stress and thus combat road violence.

Key words: design, road violence, stop motion, educational video 


\section{Tabla de Contenidos}

\section{INTRODUCCIÓN}

1.1. Descripción del problema encontrado ................................................................. 2

1.2. Pregunta de investigación ................................................................................. 4

1.3. Justificación de la investigación .........................................................................4

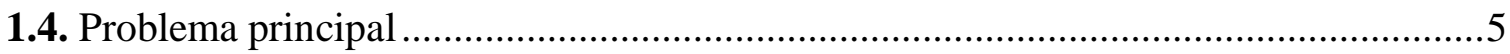

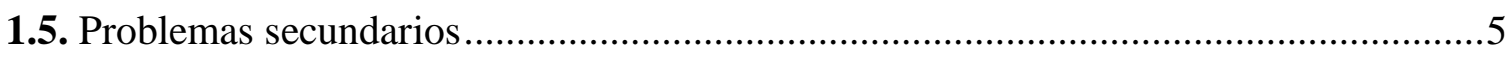

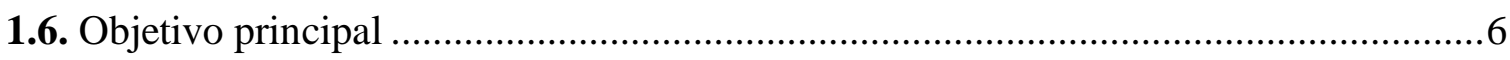

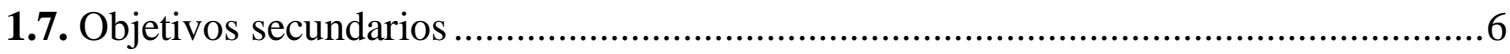

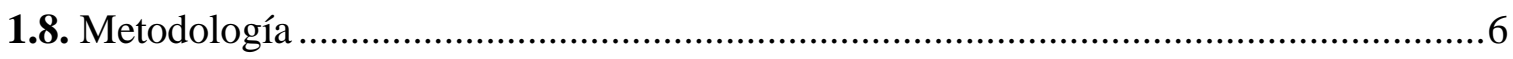

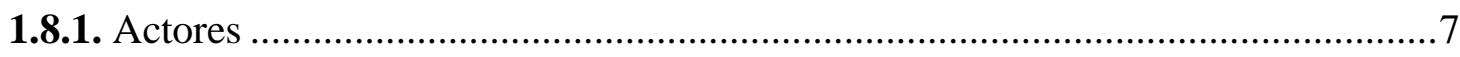

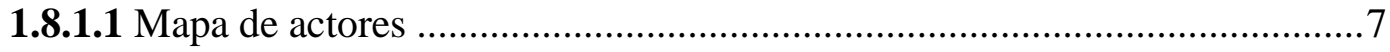

1.8.1.1.1. Conductores.......................................................................... 7

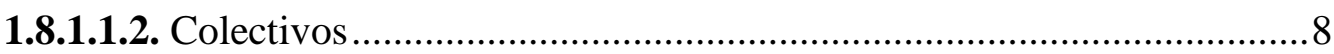

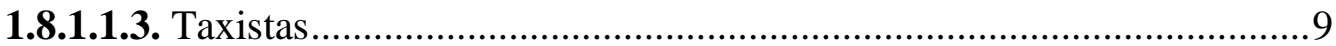

1.8.1.1.4. Choferes de bus ..................................................................... 9

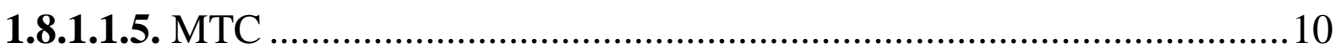

1.8.1.1.6. Peatón .......................................................................................... 10

1.8.1.1.7. Policías ..................................................................................... 10

1.8.1.1.8. Motociclistas ......................................................................... 11

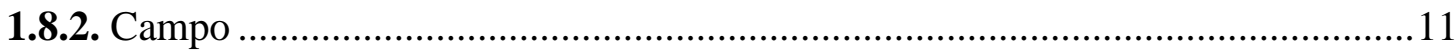

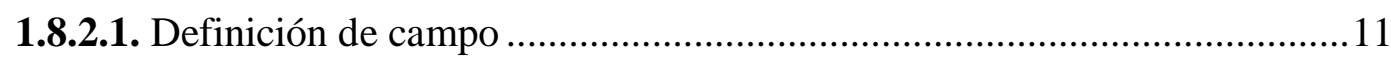

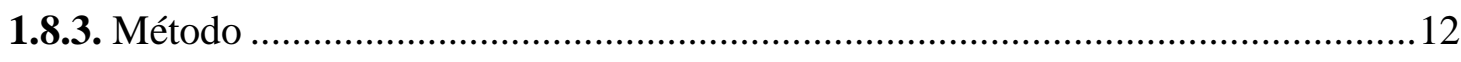

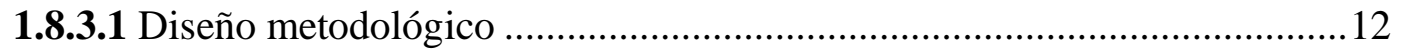

\section{CAPÍt́tulo I}

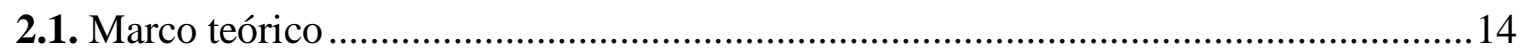




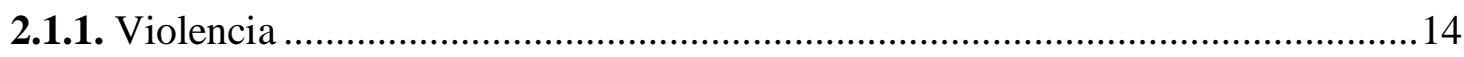

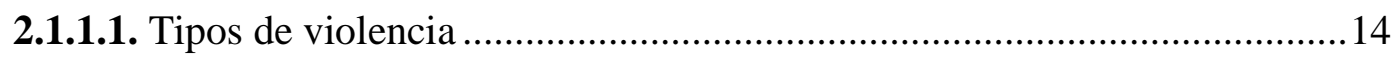

2.1.1.1.1. Violencia de género.........................................................................16

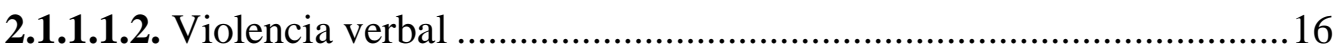

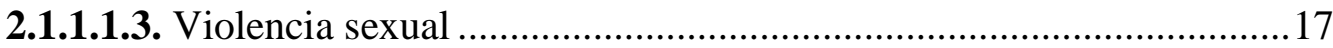

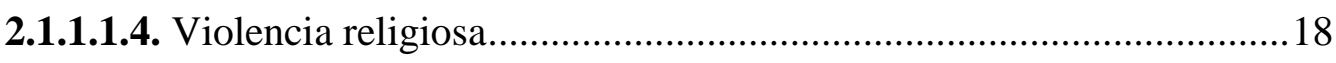

2.1.1.1.5. Violencia económica ..........................................................................19

2.1.1.2. La violencia en el Perú ......................................................................19

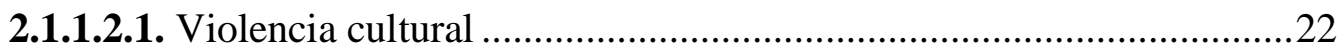

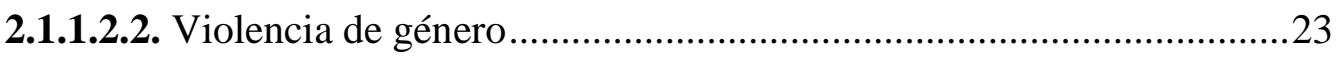

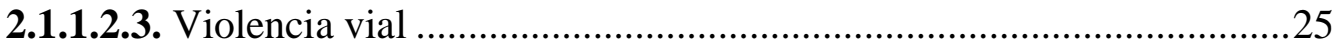

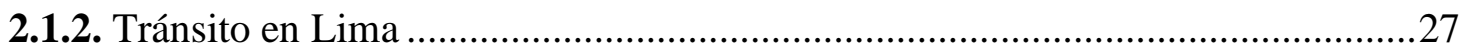

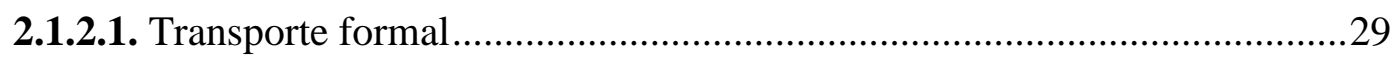

2.1.2.2. Transporte informal.................................................................................. 31

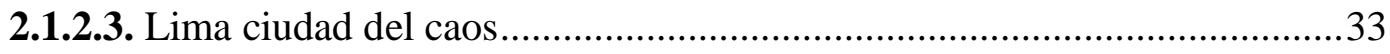

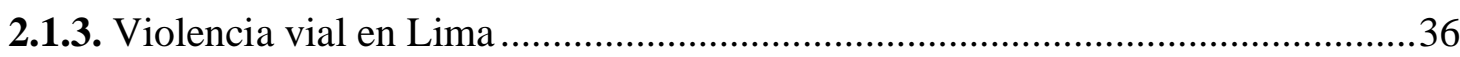

2.1.3.1. Desde el punto de vista del conductor ......................................................39

2.1.3.2. Desde el punto de vista del peatón ..............................................................40

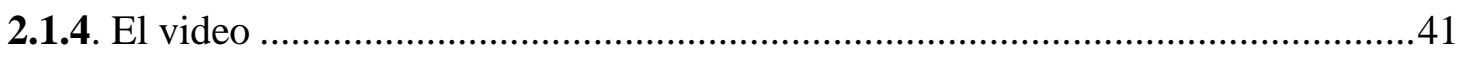

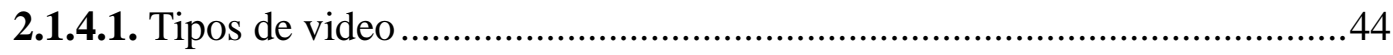

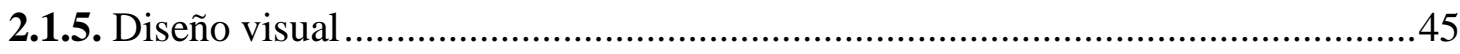

2.1.6. Diseño de video como herramienta educativa ....................................................46

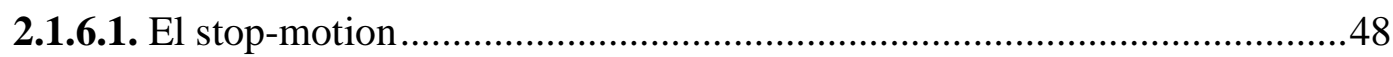

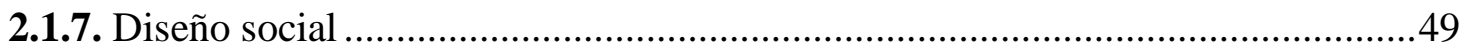

2.1.8. La importancia de la educación vial..............................................................50

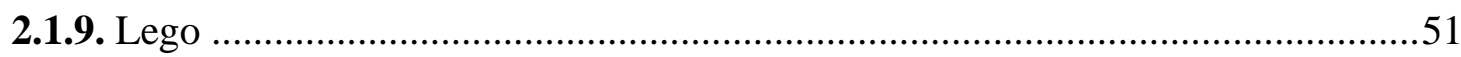

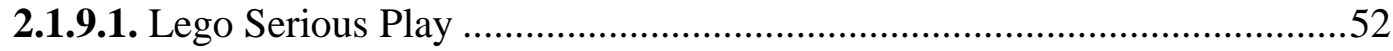

2.1.9.2. Lego en películas y videojuegos ............................................................53

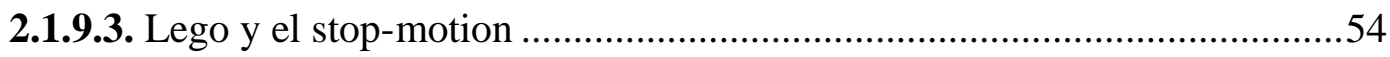

2.1.9.4. Lego Education ....................................................................................55

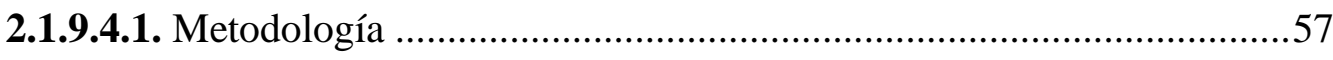


2.2. Estado del arte

\section{CAPÍTULO II}

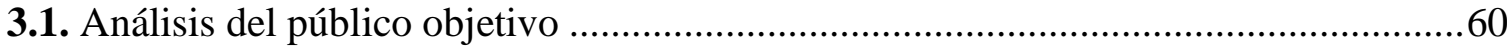

3.2. Descripción del proyecto de diseño .............................................................61

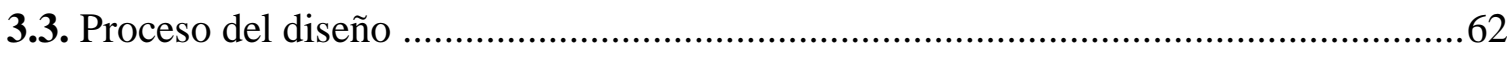

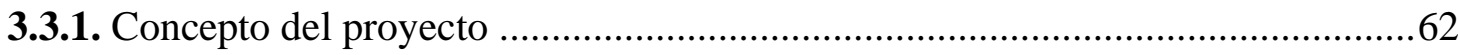

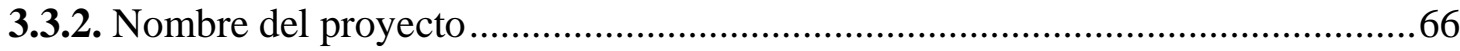

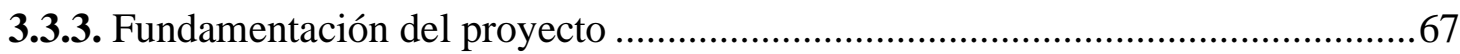

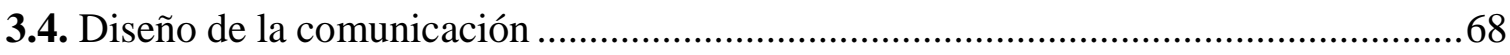

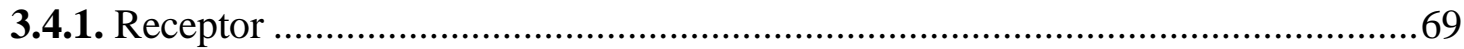

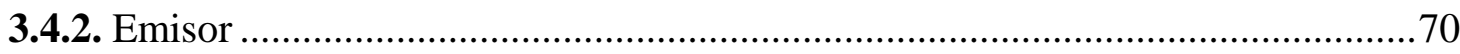

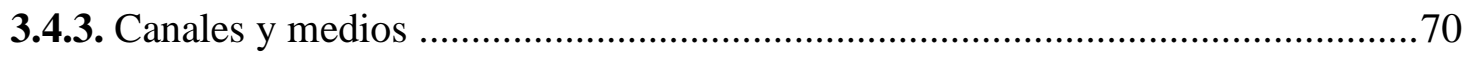

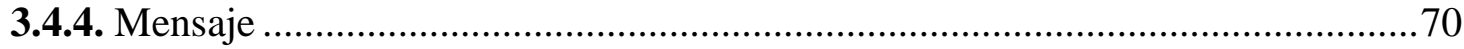

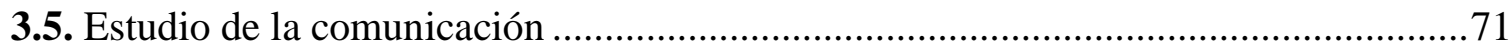

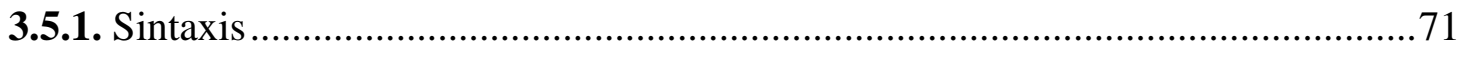

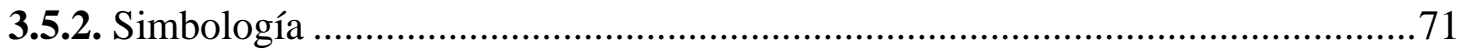

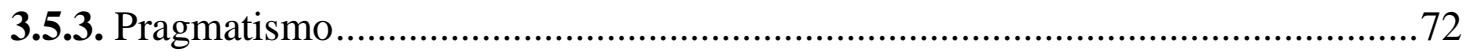

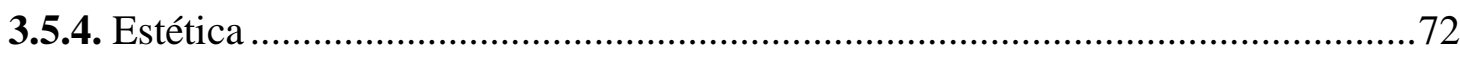

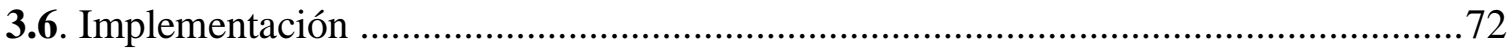

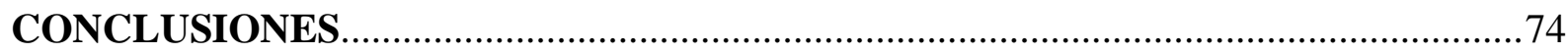

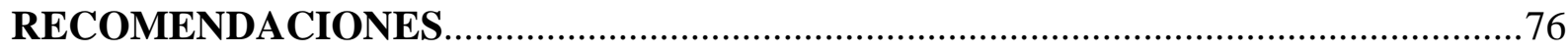

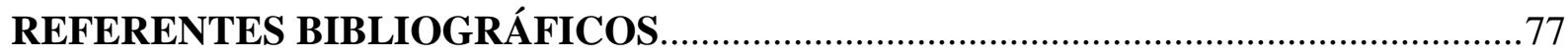

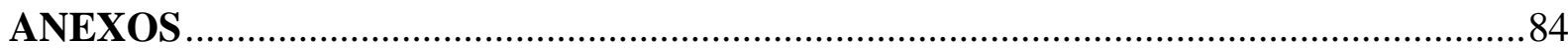

Anexo 1: Resultados de la encuesta aplicada a personas que manejan ................................84

Anexo 2: Entrevista personal a Carlos Francisco Valenzuela Martínez.................................86

Anexo 3: Entrevista personal a Mariella Hague Pérez .......................................................8

Anexo 4: Entrevista personal a Rendo Domingo Salazar Sánez ........................................90 
Anexo 5: Juicio de Pares 


\section{Listado de Figuras}

Figura 1.1. Metodología de la investigación.................................................................... 7

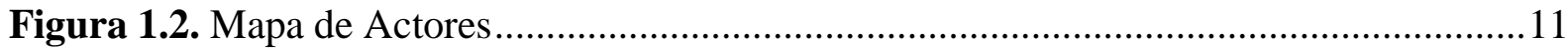

Figura 3.1. Moodboard conceptual del proyecto .........................................................63

Figura 3.2. Propuesta uno de paleta de color para el proyecto .........................................63

Figura 3.3. Propuesta dos de paleta de color para el proyecto..........................................64

Figura 3.4. Propuesta tres de paleta de color para el proyecto ...........................................64

Figura 3.5. Propuesta uno de paleta tipográfica para el proyecto .......................................65

Figura 3.6. Propuesta dos de paleta tipográfica para el proyecto .......................................65

Figura 3.7. Propuesta tres de paleta tipográfica para el proyecto ......................................66

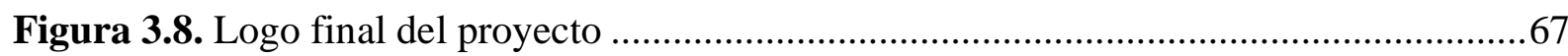

\section{Listado de Fotos}

Foto 2.1. Motociclista que no respeta los carriles designados en la Avda. Javier Prado ....... 25

Foto 2.2. Ambulancia estancada en el tráfico matutino en la Avda. Javier Prado ................. 29

Foto 2.3. Autobús obstruyendo intersección en la Avda. Arenales (cuadra 14) ....................33

Foto 2.4. Buses de transporte público y autos particulares esquivándose entre sí y traspasando

los carriles designados de manera imprudente.

Foto 2.5. Taxis y colectivos informales obstruyendo el paso para poder recoger pasajeros en

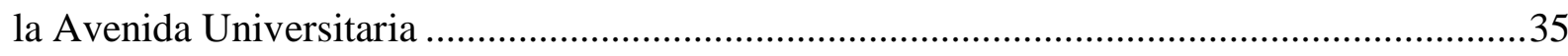

Foto 2.6. Taxi informal recogiendo un pasajero en zona de estacionamiento prohibido .........37

Foto 2.7. Colectivo informal recogiendo pasajeros y obstruyendo el tránsito ........................38 


\section{Listado de Cuadros}

Cuadro 2.1. Tabla estadística con resultados de la pregunta 8 de las encuestas realizadas a cincuenta conductores limeños

Cuadro 2.2. Tabla estadística con resultados de la pregunta 3 de las encuestas realizadas a cincuenta conductores limeños 


\section{Introducción}

En la ciudad de Lima se experimenta un problema que viene sucediendo desde hace varios años y que no solo acarrea la pérdida de horas (para el) hombre en el caos vehicular sino (que) también afecta la salud mental de quienes sufren este problema. Se parte de que el desconocimiento de las reglas básicas de tránsito genera caos vehicular que a su vez es un factor desencadenante de estrés que luego genera ira y finalmente termina en violencia vial. Y es que contamos con un nulo respeto por el reglamento de tránsito y con leyes de tránsito vehicular pésimamente implementadas, las cuales han sido mal aplicadas a la realidad del Perú y sobre todo de Lima; a su vez, las actuales calles y avenidas jamás fueron diseñadas para que más de 8 millones de personas transitaran por ellas, sea en carros, ómnibus, combis, motos, scooters eléctricas, bicicletas o a pie.

Este desarrollo está generando ciertos inconvenientes en el transporte urbano porque nuestras vías existentes están siendo sobrecargadas a su capacidad de diseño real. Hoy en día, existen problemas de congestión vehicular en casi todas las calles de Lima Metropolitana, al no tener un adecuado Sistema de Control de Transporte y Crecimiento Urbano nuestra capital está sufriendo los problemas de congestión vial. (Arias \& Valdiviezo, 2014, p.15)

Podemos afirmar que es consecuencia de una pésima planificación urbana que recae en las autoridades que han gobernado el país y sobre todo siendo específicos en la ciudad de Lima en donde los alcaldes no han podido enfrentar el problema desde la perspectiva de la 
planificación y diseño de estrategias que permitan una sana convivencia entre todos sean peatones o vehículos.

Por otro lado, el tráfico no solo genera caos vehicular, sino que también repercute en el comportamiento de las personas haciendo que adopten una actitud -en muchos casossumamente agresiva al momento de conducir debido al escaso conocimiento de las reglas de tránsito con la que el conductor promedio cuenta. Este problema -aunque resulte increíble- se remonta a siglos atrás, pudiendo ser identificado desde la época colonial, donde la impunidad y la mal llamada "criollada" -el ser más astuto o "vivo" que otros para no cumplir con las normassiempre ha estado presente como un cáncer en la sociedad peruana, repitiéndose hasta el día de hoy, no solo en el tránsito, sino también en la política y la vida cotidiana. Esta investigación se centra específicamente en cómo el caos vehicular también afecta el aspecto psicológico de las personas, especialmente si hablamos de salud mental, siendo caldo de cultivo para despertar ira y agresión entre transeúntes y conductores sea esta verbal o en algunos casos llegando a la física.

\subsection{Descripción del problema encontrado}

"Un estudio realizado por la fundación Transitemos tuvo como resultado que el 38\% de la población limeña pierde una hora y media al día en el tráfico, lo que equivale a una pérdida de 19,7 días al año por persona" (El Comercio, 2019). Es evidente que cada año el nivel de autos incrementa y junto con ello, el tráfico; sin embargo, es poco o nada lo que las autoridades hacen para que el problema siga incrementándose. Si bien se han hecho ciertas regularizaciones frente a las empresas de transporte público privado, el servicio que ofrece la ciudad misma tampoco es el mejor, a su vez, los colectivos y taxistas informales agravan más la situación. Ante lo anteriormente mencionado, Figueroa (2005) afirma que: 
Debe entenderse que se trata de servicios que pueden ser legales o ilegales y que pueden incluso operar en áreas consolidadas y centrales de la ciudad. El verdadero carácter de ellos es el de ser vehículos poco adaptados para el transporte público, de baja capacidad, operados regularmente por sus propios dueños y con un régimen menos estricto o inexistente de responsabilidad de servicio público, y con menor vigilancia pública. (p.46) En la última década la tasa de accidentes de tránsito ha aumentado de manera exponencial, registrándose más de 86000 accidentes, siendo el choque y el atropello los que poseían mayor nivel de incidencia (Choquehuanca, 2009). Asimismo, algo que resulta igual de alarmante es lo poco que las autoridades han hecho para penar estos casos, pues muchas veces se observan situaciones en donde las papeletas y multas no son pagadas a tiempo y los conductores siguen manejando, propagando una sensación de impunidad en la sociedad.

Es importante recalcar que los aspectos mencionados contribuyen a tener un tránsito elevadamente congestionado y sumado a ello, la falta de conciencia por respetar las normas y reglas básicas de tránsito por parte de los mismos ciudadanos -quienes con sus acciones formalizan día a día la impunidad y el caos-, desde aquella persona que por no llegar tarde al trabajo decide usar el servicio de un colectivo informal hasta el conductor de bus -también informal-que maneja sin brevete y con numerosas papeletas sin pagar. Es por ello que este tema es un círculo vicioso en el cual todos son actores y se hace necesario no solo un urgente programa de educación vial, sino una adecuada difusión de las leyes de tránsito. Porque ahora también es un problema de comportamiento en donde se está pendiente de la agresión, el insulto y la ofensa temeraria mientras se maneja, en donde siempre se está en estado de alerta, pues el comportamiento de todos los actores es impredecible. 


\subsection{Pregunta de investigación}

¿De qué manera el caos vehicular genera situaciones de estrés extremo que desencadena en agresiones verbales o físicas?

Son muchos aspectos a tomar en cuenta si es que se desea erradicar la impunidad y más aún la informalidad; sin embargo, esta investigación se dirige a los mismos conductores y peatones que forman parte de este círculo vicioso. Se desea averiguar por qué se siguen propagando estas conductas de informalidad que tanto afectan a la sociedad y cuál es la razón por la cual las autoridades hacen poco al respecto. De la misma manera, se desea hallar el motivo por el cual las leyes de tránsito no están bien aplicadas a la realidad limeña y en base a eso generar cambios que reduzcan el caos vehicular.

\subsection{Justificación de la investigación}

Desde un punto de vista personal, he podido vivir esta situación día a día al igual que miles de limeños más y resulta frustrante observar que a pesar de los años, la situación sigue empeorando. Es necesario hablar de este tema debido a que es un problema que se agravia con el paso del tiempo y si no se generan medidas de soluciones ahora, seguirá empeorando en los siguientes años. Asimismo, la sensación de impotencia y resignación hacen que sea urgente poder brindar soluciones inteligentes frente a una problemática tan seria como lo es el caos vehicular, pues las consecuencias se observan no solo en el tránsito sino también en el comportamiento de las personas que conducen, desde estrés hasta conductas de agresión urbana como insultos, racismo e incluso violencia de género. Son muchos los factores que forman parte de esta situación y es por ello que en esta investigación se abordarán los más importantes y determinantes para así poder identificarlos y ofrecer una solución. 
Desde el punto de vista académico, es vital que este tema sea abordado pues afecta a Lima no solo como ciudad, sino también como sociedad, las conductas de criollismo e informalidad que se observan hoy día seguirán siendo replicadas en el futuro cercano si es que no se comienzan a erradicar desde ahora. Se sabe que más de 1200 intersecciones en la ciudad están mal semaforizadas (Perú 21, 2016) y solo el $27 \%$ están interconectadas con un centro de monitorización (La República, 2014). El caos vehicular y la agresión urbana en la que desemboca el mismo son un reflejo de lo que somos los limeños como sociedad y es necesario empezar a generar soluciones que realmente se apliquen a nuestra realidad.

\subsection{Problema principal}

¿Cómo el caos del tránsito vehicular en la ciudad de Lima afecta al incremento de la agresión urbana?

El incremento de la agresión urbana verbal y temeraria a consecuencia del caos en el tránsito vehicular en la ciudad de Lima Metropolitana.

\subsection{Problemas secundarios}

Violencia de género a consecuencia del incremento de la agresión urbana verbal y temeraria a consecuencia del caos en el tránsito vehicular en Lima Metropolitana.

Xenofobia y racismo debido al incremento de la agresión urbana verbal y temeraria a consecuencia del caos en el tránsito vehicular en Lima Metropolitana. 


\subsection{Objetivo principal}

Evidenciar cómo el caos en el tránsito vehicular en la ciudad de Lima afecta el incremento de la agresión urbana.

\subsection{Objetivos secundarios}

Denunciar la violencia de género como consecuencia del incremento de la agresión urbana a causa del caos en el tránsito vehicular en la ciudad de lima.

Señalar cómo el caos en el tránsito vehicular en la ciudad de lima afecta el incremento de la agresión urbana, fomentando la xenofobia.

\subsection{Metodología}

La metodología para esta investigación recurrirá a diversos métodos como la etnografía, el video, la fotografía y la entrevista, las cuales permitirán obtener información que permita identificar hábito de conducta y comportamiento en Lima Metropolitana. Las entrevistas permitirán obtener datos de manera más discreta a interrogantes como los horarios en los que los entrevistados suelen conducir, si manejar les genera estrés o si perciben que la manera en la que los demás conducen ocasiona cambios en su comportamiento. Se eligió Lima Metropolitana debido a la congestión generada por la mala señalización existente y el deterioro de la misma en diversos sectores, el poco número de carriles para la cantidad de vehículos que transitan a diario, el gran número de motocicletas que circulan intrépidamente, los servicios de transporte informales como colectivos que generan estancamientos y la poca educación que posee el conductor limeño respecto a las reglas de tránsito, todo ello conlleva a que se desate el caos vehicular y que la ira de los conductores se manifieste en comportamientos agresivos. 
Fotografias

Evidenciar y comprobar que las personas suelen ignorar las reglas de tránsito ocasionando caos vehicular y agresión. Asimismo, permitirá saber qué reglas de tránsito son las que si se cumplen y cuales no.

\section{Encuestas}

Se encuestará a diversos conductores de la ciudad de Lima, con un amplio rango de edades para determinar su actitud frente al problema y que opinan al respecto. Permitirá saber si el tráfico y la agresión están realmente relacionados.

\section{Video}

Permitirá registrar en tiempo real el momento en que se cometen acciones temerarias al volante $y$ las reacciones de las persoans frente a las misma y determinar de qué manera se manifiesta la violencia en el tráfico.

\section{El caos vehicular que hay en la ciudad de Lima hace que las personas se comporten de manera agresiva.}

\section{Entrevistas}

Se entrevistará a facilitadores de la metodología Lego Serious Play para poder entender el alcance de esta y como este sistema ayuda a generar cambios en el comportamiento de una sociedad o grupo de personas.

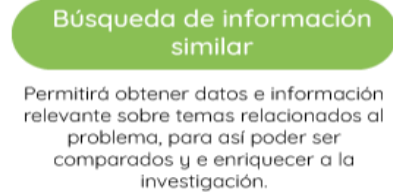

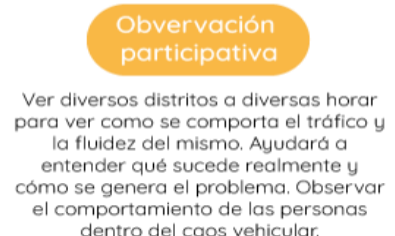
se genera el problema. Observar
dentro del caos vehicular.

Figura 1.1. Metodología de la investigación Fuente: Propia

\subsubsection{Actores}

\subsubsection{Mapa de actores}

\subsection{Conductores}

El conductor cotidiano que va a su trabajo de lunes a viernes en horarios de oficina, por lo general es uno de los principales actores que genera tráfico debido a que son bastantes quienes tienen esta rutina. En los últimos veinte años, gracias a las facilidades de las importaciones de vehículos de primera y segunda mano ofrecida por la República Peruana, desde el gobierno del Ex Presidente ALBERTO FUJIMORI, el parque automotor creció rápidamente y esto sin una planificación preventiva y adecuada del transporte urbano. Hoy en día, existen problemas de congestión vehicular en casi todas las calles de Lima Metropolitana, al no tener un adecuado Sistema de Control de Transporte y Crecimiento Urbano. Nuestra capital está sufriendo los problemas de congestión vial. (Arias \& Valdiviezo, 2014, p.20)

La mala intervención de la policía nacional en dirigir el tránsito en ciertas calles intersecciones de Lima agudiza aún más el problema, si bien se han instalado semáforos inteligentes que 
regulan el flujo de tránsito, estos colapsan al intervenir los policías y distorsionar el flujo natural de vehículos. En el trabajo de campo realizado en la Av. Javier Prado se evidencia que en el tramo comprendido entre la Av. Arequipa y Av. Rivera Navarrete el actuar de los policías genera una pérdida de tiempo de hasta 25 minutos solo para cruzar ese tramo.

\subsection{Colectivos}

El servicio de colectivo es como una especie de taxi, pero comunitario, y se desplaza a través de una sola ruta larga tipo La Molina, todo Javier Prado hasta la entrada al Callao. Otra ruta es Rímac, pasando por Av. Tacna, Av. Wilson y Av. Arequipa hasta el centro de Miraflores. En estas rutas los pasajeros suben y pagan algo más que un pasaje de bus, pero es más rápido por tener pocos pasajeros. Las unidades más utilizadas son carros tipo sedán de 4 puertas que pasan desapercibidos en muchas ocasiones frente a los fiscalizadores. En el trabajo de campo realizado se evidencia que operan con total impunidad incluso en rutas que aplican el sistema pico y placa y que se supone restringido para determinados números; pero para estos choferes es letra muerta. Esto genera también obstrucción del tráfico al no tener paraderos fijos, a pesar de estar penado por la ley, este servicio subsiste debido a la demanda de personas que lo utilizan y al pobre servicio que ofrecen los buses administrados por la municipalidad. En este caso es evidente que el principal motor de esta informalidad es el mismo usuario que permite la existencia de este servicio al utilizarlo todos los días en todas las rutas señaladas.

\subsection{Taxistas}

El rubro de taxis ha ido evolucionando en las últimas décadas, pues en un inicio, la gran mayoría de taxistas operaban de manera informal y sin pagar impuestos. Figueroa (2005) explica que: 
Una franja de población desplazada de sus antiguos trabajos encontró en el transporte una actividad con suficiente desregulación como para poder ingresar, y con capacidad de sustentación laboral en el mediano plazo, lo que promovió la proliferación de propietarios que invertían sus indemnizaciones en vehículos (taxis, busetas, furgones y diversos otros tipos de transporte informal o precario), y se transformaban en transportistas profesionales. (p.46)

De esta manera, muchas personas que atravesaban una situación económica difícil decidían dedicarse al transporte público informal.

Aunque en la actualidad se ha tratado de mejorar el sistema de permisos para taxis, siguen existiendo fallas. Más ahora que han salido nuevos servicios que funcionan mediante aplicaciones, como Uber y Beat, en donde la principal característica es que cualquiera con un auto puede ofrecer un servicio de taxi. Ello ofrece al usuario una experiencia más segura y más económica.

\subsection{Choferes de bus}

Hay quienes trabajan para el servicio de transporte ofrecido por la municipalidad; sin embargo, la gran mayoría trabaja para empresas privadas. Muchos de estos choferes manejan de manera imprudente y no siempre respetan las leyes de tránsito, suelen acumular multas de tránsito y algunos manejan aún estando suspendidos y sin brevete.

\subsection{MTC}

El Ministerio de Transportes y Comunicaciones (MTC) es el órgano del Poder Ejecutivo responsable del desarrollo de los sistemas de transporte y de la infraestructura de las comunicaciones y las telecomunicaciones del país. Su labor es crucial para el desarrollo 
socioeconómico porque permite la integración regional, nacional e internacional, la facilitación del comercio, la reducción de la pobreza y el bienestar del ciudadano.

De esta manera, el MTC constituye el ente rector y promotor de eficientes sistemas de carreteras y ferrovías, de transporte aéreo, marítimo y fluvial, y de redes de telecomunicaciones integradoras, así como de los programas de concesiones en los ámbitos de su competencia. Por medio de los órganos de control e instituciones adscritas, el sector también supervisa el correcto funcionamiento de las vías terrestres, de las rutas aéreas y acuáticas, y las telecomunicaciones. En el transporte terrestre, el MTC es ejecutor y/o promotor de iniciativas destinadas a la construcción de nuevas carreteras, así como de la puesta en marcha de grandes sistemas de transporte público (MTC.com.pe).

\subsection{Peatón}

Actor secundario que suele generar caos mediante otros actores, como colectivos informales o buses. Al usar estos servicios genera tráfico en las calles, ya sea al parar a un taxista o un bus en una calle o paradero prohibido, deteniendo la circulación de la misma y generando así malestar en los demás conductores.

\subsection{Policías}

Quienes se encargan de hacer respetar la ley. Si bien están esparcidos en lugares donde se concentra el tráfico, siguen siendo pocos para controlar todo el caos que se genera en las horas punta. Debido a ello, es que muchos infractores siguen quedando impunes y muchas de estas infracciones siguen repitiéndose día tras día.

\subsection{Motociclistas}

En los últimos años ha habido un notable crecimiento en el uso de estos vehículos debido a aplicativos de delivery; sin embargo, muchos conducen de manera imprudente y no respetan 
las leyes de tránsito para poder hacer los envíos más rápido, generando así más desorden y caos en las calles.

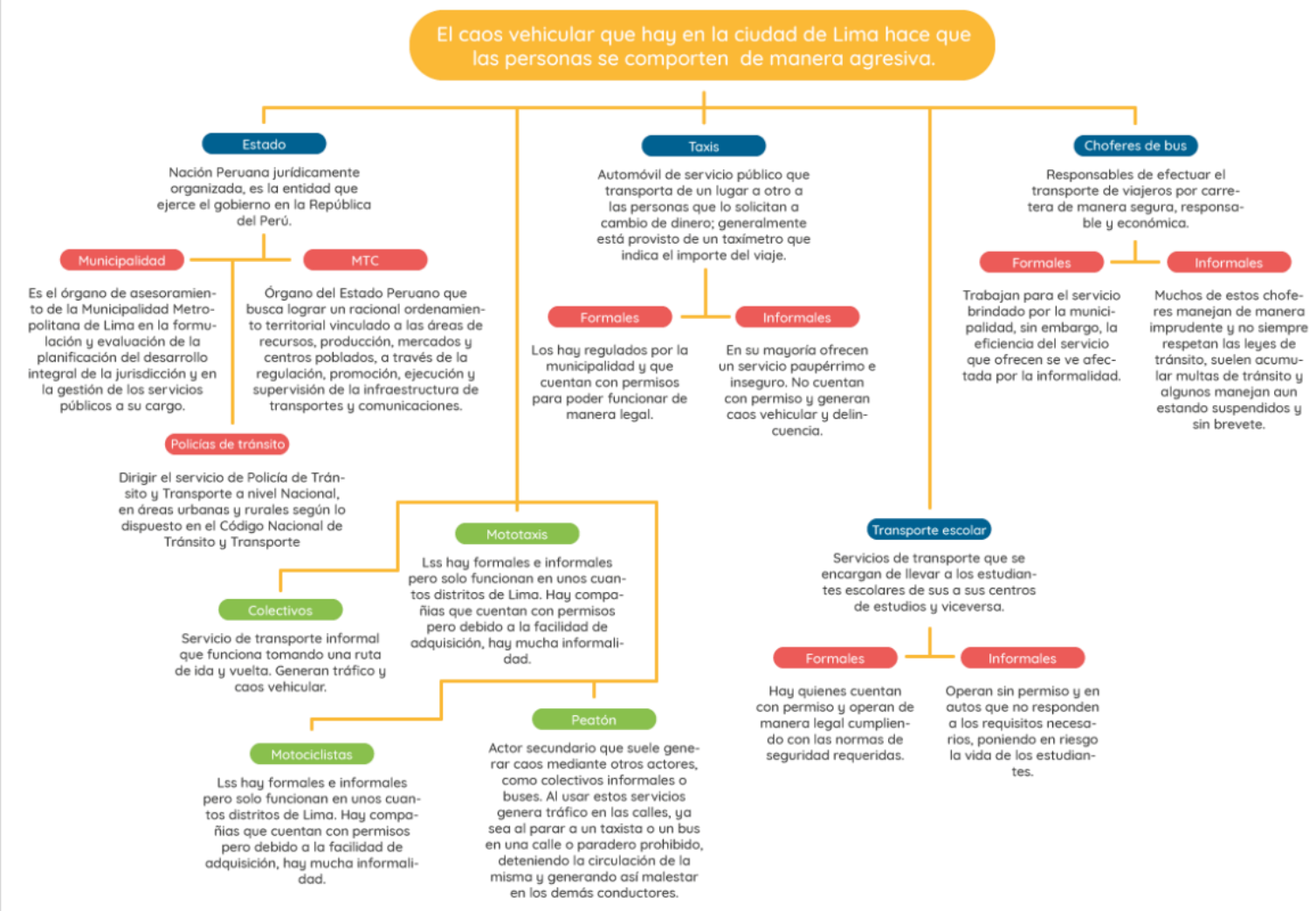

Figura 1.2 Mapa de Actores

Fuente: Propia

\subsubsection{Campo}

\subsubsection{Definición del campo}

En esta investigación identificar la relación que existe entre campo y actor es simbiótica.

La ciudad de Lima y sus calles son el lugar de los hechos, pero también se comporta a manera de actor, como se había mencionado anteriormente. Señalar unas calles específicas en donde suceden los hechos puede ser una manera de limitar el espacio de estudio, pero en este problema consideramos que este problema sucede en todas partes. En el trabajo de campo realizado en diversos distritos de la ciudad de Lima se comprueba como la falta de conciencia hacia el reglamento de tránsito, el respeto a la autoridad (policía) y el respeto al otro sea peatón u otro 
chofer es absolutamente nulo, generando caos, congestión y ello desemboca justamente en la violencia por la pérdida de la paciencia en determinados conductores y el estrés generado por dichas congestiones. Esta situación es transversal y según las observaciones realizadas, una combinación de congestión, largo tiempo en un vehículo y faltas al reglamento dan lugar a insultos, peleas, y en algunos casos hasta violencia física.

Por ello el concepto de círculo vicioso se entiende mejor en esta parte debido a que la ciudad se comporta muchas veces como un espacio en donde la impunidad y la informalidad son ampliamente permitidas. La ciudad, que somos todos nosotros, genera un desorden inimaginable en donde quien no recurre al criollismo y a la informalidad no llega a ningún lado; de la misma manera, estas actitudes que resultan tan dañinas para la ciudad no permiten un desarrollo como sociedad. A su vez este mismo espacio que es dañado sigue siendo lugar de informalidad generándose así un ciclo interminable.

\subsubsection{Método}

\subsubsection{Diseño metodológico}

La metodología propuesta busca por un lado entender los distintos puntos de vista que coexisten en este problema, tanto el de los conductores como el de las autoridades y los choferes de servicios de transporte. Por otro lado, busca identificar la razón por la cual las leyes no se respetan y por qué hay tanta informalidad que no está siendo penada.

- Entrevistas: Permitirán una exploración cualitativa sobre la perspectiva de los conductores como de las autoridades, además de conocer las razones y características de los taxistas informales. 
- Observación participante: Permitirá establecer el comportamiento entre conductores en hora punta, observar y analizar sus actitudes y reacciones, y ver la relación que tiene el caos vehicular con la agresión urbana.

- Etnografías aplicadas: Permitirá tener una mejor visión general sobre las relaciones entre los distintos grupos de actores.

- Registro audiovisual: Servirá para documentar las infracciones e informalidades que se evidencian día a día en el tráfico limeño. 


\section{CAPÍTUlO I}

\subsection{Marco teórico}

\subsubsection{Violencia}

La violencia, según un informe realizado por la (Organización Mundial de la Salud [OMS], 2002), es planteada como un problema de salud pública. Está definida como el uso intencional de la fuerza o de poder físico a manera de amenaza en contra de un individuo, hacia uno mismo, hacia un grupo o una comunidad (OMS, 2002). La violencia no solo genera daños físicos, en muchos casos se puede hacer evidente mediante el daño psicológico y mental ocasionado. "La violencia tiene consecuencias no sólo ejemplificadas en el precio del dolor y la angustia que causa en el ser humano, sino que permea un malestar psicológico que surge del temor que infunde" (Ambert-Cabrera, 2016, p.4).

Debido a lo anteriormente mencionado, se entiende que la violencia no tiene necesariamente que ser cuantificada por el nivel de sangre que se pueda evidenciar para ser calificada como tal, en ocasiones, muchos tipos de violencia están expresados y ejecutados mediante la palabra, vinculada al aspecto psicológico, sexual, económico, etc. Cisneros (2011) afirma que "la violencia estará definida por el punto de vista de quien la interprete, o bien por la posición de la víctima o el victimario" (p.59).

\subsubsection{Tipos de violencia}

Como se mencionó anteriormente, la violencia puede ser identificada en distintas formas y los daños generados repercuten no solamente en lo físico sino en el aspecto psicológico y emocional del individuo (Briceño-León, 2002). En las siguientes líneas se explicarán diversos 
tipos de violencia, que están entre las más recurrentes en la sociedad. El teórico noruego, Johan Galtung, desarrolló tres niveles de análisis sobre la violencia, que representaba cómo la confluencia de factores se unía en determinados momentos de la historia que dieron paso a que la violencia se propagase.

La violencia directa es lo que la gente piensa comúnmente cuando se piensa en el tema, representa comportamientos que pueden llegar a amenazar con la vida misma o disminuir la capacidad de satisfacer las necesidades básicas de un individuo mediante el asesinato, mutilación, acoso sexual y manipulación emocional.

Por otro lado, la violencia estructural representa la manera sistemática en la que algunos grupos son privados de diversos bienes, servicios y necesidades humanas básicas. Estas pueden ser formales dentro de estructuras legales que promulgan la marginalización, un claro ejemplo de esto es el Apartheid en Sudáfrica. Mandela se pronunció, comentando que en aquellos lugares en donde los líderes recurrían al uso de actos violentos, tendían a promulgar y extender la violencia mediante su ejemplo (OMS, 2002). También pueden ser informales, concebidas bajo prácticas comunes, como el acceso limitado a la educación o salud.

La violencia cultural representa la existencia de normas sociales prominentes y predominantes que hacen que la violencia directa y estructural pasen desapercibidas o incluso que la gente las perciba como aceptables, por ejemplo, la creencia de que los africanos eran primitivos e intelectualmente inferiores en comparación a la raza caucásica, lo cual dio paso a la trata de esclavos africanos (Galtung, 2004). La manera en la que Galtung define la violencia cultural ayuda a explicar cómo ciertas ideologías pueden arraigarse tanto en una sociedad, que llegan a funcionar de maneras absolutas e inevitables y son reproducidas sistemáticamente por 
generaciones. Estas tres formas de violencia están interconectadas y se refuerzan mutuamente, entenderlas de manera clara es crucial para esta investigación.

\subsection{Violencia de género}

Como ha sido explicado en las líneas anteriores, violencia es aquella conducta que se realiza de manera consciente para generar algún tipo de daño en la víctima. La OMS, desde la perspectiva de los estudios de género, dice que las relaciones sociales entre hombres y mujeres son desiguales a favor de los primeros, por ende, cuando se habla de violencia de género, no se habla de violencia desde mujeres hacia hombres ni entre mujeres, aunque esas violencias existan; violencia de género es violencia desde un sector dominante de la sociedad hacia uno sometido. Larrauri (2007) afirma que:

No es difícil comprobar que en la mayoría de las sociedades hay un género dominante y es el masculino, las mujeres quedan reducidas a lo doméstico o reproductivo y cuando se integran al mundo laboral, muchas veces son peor remuneradas que los varones. (p.63) La mayoría de mujeres son educadas en el recato y la sumisión y a los hombres se les inculca el liderazgo, la fortaleza y la agresividad como características deseables. Muchas veces la justicia invisibiliza la situación de violencia de género al confundirla con la violencia familiar o doméstica, que no es lo mismo. Hay tres clases de violencia de género, entre ellas está la violencia física, la violencia psicológica y la violencia sexual.

\subsection{Violencia verbal}

Es una forma de maltrato en la que una persona somete y controla a otra con diversos comportamientos hirientes, insultos, humillaciones, culpabilización, menosprecio, amenazas y chantajes entre otros (Carrasco, 2007). Cualquiera de estos comportamientos, sean activos o pasivos y que agredan la estabilidad emocional de la víctima de manera sistemática y reiterada 
en el tiempo son considerados como violencia verbal, la cual posee secuelas psicológicas. El objetivo de tales comportamientos es que la víctima se sienta desvalorizada, culpable o intimidada, aprovechando el afecto o menosprecio que en general la víctima siente por el agresor para abusar de la situación. Cabe recalcar que, aunque se da especialmente de hombres hacia mujeres también sucede de manera inversa, aunque con menor número de incidencia.

\subsection{Violencia sexual}

Todo individuo tiene derecho a vivir y relacionarse en un entorno sin violencia, la decisión de compartir la intimidad con alguien está ligada al ejercicio de la propia sexualidad y absolutamente nadie puede tomar esa decisión por la otra persona. Tener relaciones sexuales es una decisión que conlleva muchas responsabilidades, puesto que involucra temas como el bienestar físico, mental y emocional, así como las consecuencias que pueden surgir a raíz de esta decisión. Cuando una persona obliga, presiona o engaña a otra para tener relaciones sexuales, está ejerciendo una conducta sexual abusiva y esto puede traer graves consecuencias como trastornos de sueño, inestabilidad, cambios de humor, miedos repentinos, bajo rendimiento, ansiedad, depresión, problemas alimenticios, conductas autodestructivas, problemas para socializar, etc. "El abuso sexual está considerado como unos de los cinco eventos más traumáticos por los que una persona puede pasar y las consecuencias pueden variar dependiendo si el abusador es un familiar, un extraño o alguien mayor que la víctima” (Osborne, 2009, p.143).

Cuando una persona invade la sexualidad de otra, aprovechándose de que no se está completamente consciente, como al estar dormido, enfermo o bajo el efecto de alguna sustancia y no se tiene control ni poder de decisión, también es considerado como abuso sexual.

Hay distintas formas de abuso sexual, la más común es cuando hay contacto físico, pero también puede ocurrir sin la presencia de este, como cuando sucede de manera cibernética o 
simplemente obligar a alguien a desnudarse o espiar a alguien mientras está desnudo. Al contrario de lo que se cree, el abuso sexual generalmente no se da en las calles o en personas desconocidas, más del $75 \%$ de los casos de abuso sexual sucede dentro de los hogares propios o de algún familiar, vecino o amigo y más del $95 \%$ de las personas que abusan sexualmente son personas con las que existía confianza (Larrauri, 2007).

\subsection{Violencia religiosa}

Cuando se habla de violencia y salvajismo religioso, se cree que se está hablando de sucesos que ocurrieron hace siglos; sin embargo, no siempre es así. Es una forma de intolerancia contra las creencias o prácticas religiosas de una persona o un grupo. Puede ser motivada por creencias religiosas diferentes como también por otras ideologías, así como también por un sentido antirreligioso. Los conflictos religiosos han existido a lo largo de casi toda la historia porque la religión ha conseguido convencer a muchas personas de que las ideas que proponen son las verdaderas y que deben defenderlas, lo cual ha generado los fanatismos. Las persecuciones religiosas constituyen un caso extremo de intolerancia que implica el maltrato, la violencia y la agresión, las cuales pueden provocar graves accidentes e incluso la muerte. Usualmente, las persecuciones de esta naturaleza florecen por la ausencia de tolerancia religiosa, libertad de religión y pluralismo religioso (Žižek, 2017). La persecución, en este contexto, puede suponer agresión, apedreamientos, torturas, prisión, ejecuciones injustificadas, negación de beneficios y derechos, confiscación de bienes, destrucción de propiedades o incitamiento al odio entre otros. 


\subsection{Violencia económica}

Es el control de los ingresos económicos de un miembro de la familia, ya sea de sus bienes o la retención que pudiese hacer de manera ilegal, el menoscabo, la destrucción, la desaparición, también que este ocupe sus bienes o no le permita tener acceso de alguna manera a los recursos económicos de un miembro familiar (Bodelón, 2015). También constituye que uno de los padres no dé cumplimiento con su obligación alimentaria o el acreedor alimentario aun cuando esta sea exigida por una autoridad judicial en una sentencia.

Las principales víctimas de este tipo de violencia suelen ser la pareja, hijos o adultos mayores. En un matrimonio, cuando uno de los padres trabaja y el otro no, normalmente el segundo suele atender las necesidades del hogar, por ende, quien trabaja adopta un rol de proveedor, el cual posee un control absoluto sobre el dinero, es decir, condicionará en todo momento qué cantidad de dinero le da, en qué se lo debe de gastar y cómo se debe de

administrar. De la misma manera, cuando un menor de edad hereda bienes y aún no está en edad jurídica para poder administrar estos bienes, corresponde hacerse cargo al familiar más cercano; es ahí en donde se pueden aprovechar de esta incapacidad jurídica para poder malversar esos fondos (Vázquez, 2014).

\subsubsection{La violencia en el Perú}

La reflexión psicoanalítica sobre la agresividad y la violencia permite que con esos conceptos podamos reflexionar fenómenos sociales (Lacan, 1948). Existe una diferencia entre la intención agresiva y la tendencia a la agresividad, que sirve para designar un cúmulo de comportamientos del yo respecto al dominio y al nivel de agresividad requerida para las relaciones humanas y para salir de un mundo propio, romper esquemas y adentrarse en el mundo 
de las relaciones de los demás y la tendencia agresiva que corresponde de mayor manera a la pulsión de muerte.

En el Perú, uno de los principales problemas, según una encuesta realizada por el Instituto Nacional de Estadística e Informática, es la delincuencia. El 47\% de la población piensa así. Problemas como la pobreza, la falta de empleo entre otros han sido desplazados por la delincuencia.

La inseguridad ciudadana y la agresión urbana cada día generan más temor en la población, un $88 \%$ de los ciudadanos cree que en los próximos 12 meses les va a suceder un hecho delictivo, a su vez, las cifras indican que en la actualidad se estima que $29,5 \%$ de peruanos han sido víctimas de alguno de estos sucesos, ello quiere decir que aproximadamente 30 de cada 100 peruanos han tenido que pasar por esta experiencia al menos una vez en sus vidas. (Rabanal, 1996, p.78)

En el año 2018, ocurrió un asalto masivo en el distrito de La Victoria, lo cual es una muestra más de cómo el crimen se vuelve más organizado, con asaltos y robos que demuestran por qué la inseguridad ciudadana es el problema más importante del país, según la ultima encuesta del barómetro de las Américas. Esta realidad se ha abordado a través de los años con cambios en la infraestructura y herramientas que no han demostrado grandes resultados en la policía, hace falta ver la seguridad del país como una problemática que encierra diferentes factores como las condiciones de vida. Las brechas de acceso a servicios como agua, educación y salud crean el ambiente para que las personas se tornen a la delincuencia, por ello hacen falta políticas públicas que mejoren la calidad de vida de los ciudadanos, con esta estrategia se atacará el problema desde su base con el objetivo de disminuir la gestación de nuevos delincuentes (Sandoval, 2004). Una reforma necesaria es poder fortalecer a la policía con logística para 
combatir la delincuencia en las calles frente al crimen organizado, con los especialistas adecuados y el apoyo de oficiales preparados será posible evitar la propagación de bandas delictivas que amenazan con la tranquilidad de los ciudadanos. Es necesaria una estrategia que visualice la inseguridad ciudadana desde las condiciones que llevan a delinquir. Con esta reforma integral, el Perú podrá encaminarse a ser un país más seguro donde los ciudadanos puedan desenvolverse sin miedo en los espacios públicos.

En el caso de los homicidios, Lima no es la ciudad con los indicadores más altos, incluso con sus cinco homicidios por cada cien mil habitantes, está por debajo del promedio nacional. La tasa de homicidios en el Perú es alrededor de siete muertes por cada cien mil personas; sin embargo, en ciudades en el norte del país como Tumbes, Barranca, Huacho y Trujillo, las tasas son considerablemente más elevadas. En el caso de Tumbes, se estiman 35 muertes por cada cien mil habitantes. Contar con los datos adecuados permitirá enfrentar mejor el problema, no obstante, existe otro problema que resulta muy grave y es la falta de denuncias que realizan los ciudadanos ante estos crímenes. Las cifras dan como resultados que casi un $85 \%$ de los afectados decide no denunciar, en la mayoría de los casos, la razón se debe a que el ciudadano promedio no espera mucho por parte de las autoridades y siente que la ayuda que la ley puede otorgarles es poca o nula (Garmendia, 2015). Según una encuesta del Instituto de Integración, apenas 1 de cada 5 peruanos se encuentra satisfecho con la denuncia que hicieron en la comisaría. A pesar de ello, estos datos ayudan a poder identificar mejor los distintos problemas existentes para poder actuar y generar medidas de solución.

Finalmente podemos evidenciar que, en el trabajo de campo realizado, un tipo de violencia que está teniendo mayor importancia es la violencia vial, en donde los ciudadanos, presos del estrés y de una pérdida considerable de tiempo en las calles de Lima, pierden los 
papeles, la cordura y la ecuanimidad y se entregan al insulto, a las acciones temerarias ocasionando incluso hasta la muerte de seres inocentes que nada tienen que ver con los problemas mencionados. Así tenemos noticias como aquella en donde una joven atropelló a 3 personas y mató a 2 por realizar una acción temeraria con su vehículo al ir insultando a otro chofer. Y esto no hace más que comprobar que no hay un distrito específico o una calle, en particular, sino que es en cualquier parte de la ciudad donde se pueden desencadenar estos hechos de violencia vial.

\subsection{Violencia cultural}

El racismo es un fenómeno mundial, el cual ha atravesado gran parte de la historia humana junto con el dinero y el poder, a los cuales está muy ligado. Al racismo le debemos gran parte de los conflictos y miserias de nuestra llamada civilización. En las siguientes líneas se abordará el origen del racismo y discriminación en el mundo y en el Perú.

El racismo es una ideología que sirve para legitimar los privilegios de unos y la exclusión de otros, pero no en base a sus cualidades sino a cuestiones biológicas. Desde el África, el homo sapiens migró a otras partes del mundo y poco a poco adquirió distintas características físicas, que se vieron reflejadas en el color de la piel, el color de los ojos, el color del cabello, entre otros (Wieviorka, 2003). Estas características se definieron de acuerdo al clima, a la alimentación y a la adaptación del hombre a su medio ambiente. Con el tiempo, el ser humano empieza a desprenderse de la melanina y empieza a adoptar un pigmento de piel más claro, para así poder asimilar los rayos solares de manera más eficiente. Rasgos físicos como una nariz ancha eran importante en la región africana debido al caluroso clima, puesto que permite una mejor ventilación en los pulmones; sin embargo, el ser humano al migrar a los territorios nórdicos 
empieza a tener unas fosas nasales menos pronunciadas y anchas, debido al frío de la región el cual podría matar al individuo por congelamiento (Van Dijk, 2019).

El racismo científico es un asunto internacional que defendían diferentes teóricos en Francia fundamentalmente y postulaba una identificación entre lo blanco y la civilización en donde se presenta la idea de que los más altos niveles de cultura de la humanidad solo podían encontrarse en la raza blanca. Para Gobineau (1853), los germanos noroccidentales eran la única raza pura que procedía de los arios, ya que las demás estaban mezcladas con la raza negra y la amarilla.

El racismo como ideología de discriminación ha atravesado las diversas etapas de la historia humana. Se pueden identificar tres tipos de racismo en la sociedad peruana a través del tiempo, el primero en la época colonial, era religioso y cultural, los indios eran considerados paganos y bárbaros. El segundo, en el siglo XIX, que discriminaba a los indígenas analfabetos y decía que algunas razas eran más aptas para el desarrollo y la civilización. Por último, el tercero, a partir del siglo XX hasta nuestros días, cuando lo étnico racial deja de ser el único elemento de discriminación, es decir, cuando el dinero y la educación te da superioridad sobre otros (Rojas \& Zapata, 2013).

\subsection{Violencia de género}

En el Perú existe una cultura de violencia que ha sido heredada y replicada siglo tras siglo desde la llegada de los españoles. Hay numerosos estudios que desvelan que en la cultura inca y preinca existía un sistema igualitario entre géneros, en donde tanto el hombre como la mujer tenían el mismo reconocimiento frente a su sociedad y ambos podían asumir cargos igual de importantes (Rabanal, 1996). Sin embargo, con la llegada de Pizarro y la implementación de la colonia, se genera un cambio radical en donde el género masculino pasa a tener un papel 
prioritario durante la república. Esto ha generado que el rol de la mujer haya pasado a un segundo plano y que sus derechos no sean respetados.

A pesar de los esfuerzos realizados el último siglo por muchas mujeres alrededor del mundo, es lamentable ver como hasta el día de hoy continúan siendo objeto de discriminación y feminicidio, en donde la sociedad como conjunto maltrata, violenta y mata a la mujer simplemente por una condición de género. Ello es generado desde el momento en que se crían a los niños, pues se tiende a asignar comportamientos y actitudes a cada género, otorgándole al varón un rol más dominante mientras que la mujer recibe un rol más sumiso y servicial, por ende, en el subconsciente colectivo, se atribuyen connotaciones de debilidad e inferioridad a la mujer (Boesten, 2008).

El machismo es uno de los principales factores para que exista la discriminación hacia la mujer y sus derechos, este machismo, como ya ha sido mencionado, se inculca en los hogares. Ante ello Rodríguez (2009) afirma que "muchas veces son los mismos padres quienes promueven que el varón posea más libertades y determinados beneficios a lo largo de su crecimiento, mientras que a la mujer se le priva de ellos" (p.295). En la sociedad, el machismo también puede ser identificado dentro de la religión católica, en donde relega a la mujer a un segundo lugar, otorgándoles roles relacionados con el hogar y la maternidad sin que ella tome una decisión sobre el curso que va a tomar su vida, también se podría inferir de que esta es una de las razones principales por las cuales no hay mujeres que dirijan iglesias en el Perú. A nivel de educación, se siguen replicando determinados estereotipos asociados a los géneros, debido a esto, no se cuenta con una educación igualitaria en donde ambas partes sean educadas bajo las mismas condiciones (Rius, 2000). Asimismo, el tema de la sexualidad también resulta fundamental porque el Estado o los diferentes grupos de poder quieren acondicionar a la mujer a 
determinados roles. La sexualidad debe ser un atributo de uso libre para ambos géneros, en donde se tenga libre albedrío para ejercerla como cada individuo considere conveniente.

\subsection{Violencia vial}

Incremento de agresividad, congestión vehicular y mayor imprudencia por parte de los conductores lideran los factores por los cuales es más probable sufrir un accidente de tránsito en la actualidad. Es clave entender que el espacio público, por su propia naturaleza, tiene bastantes usuarios como ciclistas, conductores, peatones entre otros, debido a ello se vuelve un espacio friccionado. "La capacidad de tolerancia, la prudencia al conducir y manejar a la defensiva es esencial para que no se produzcan situaciones de riesgo" (Gallegos, 2011, p.115).

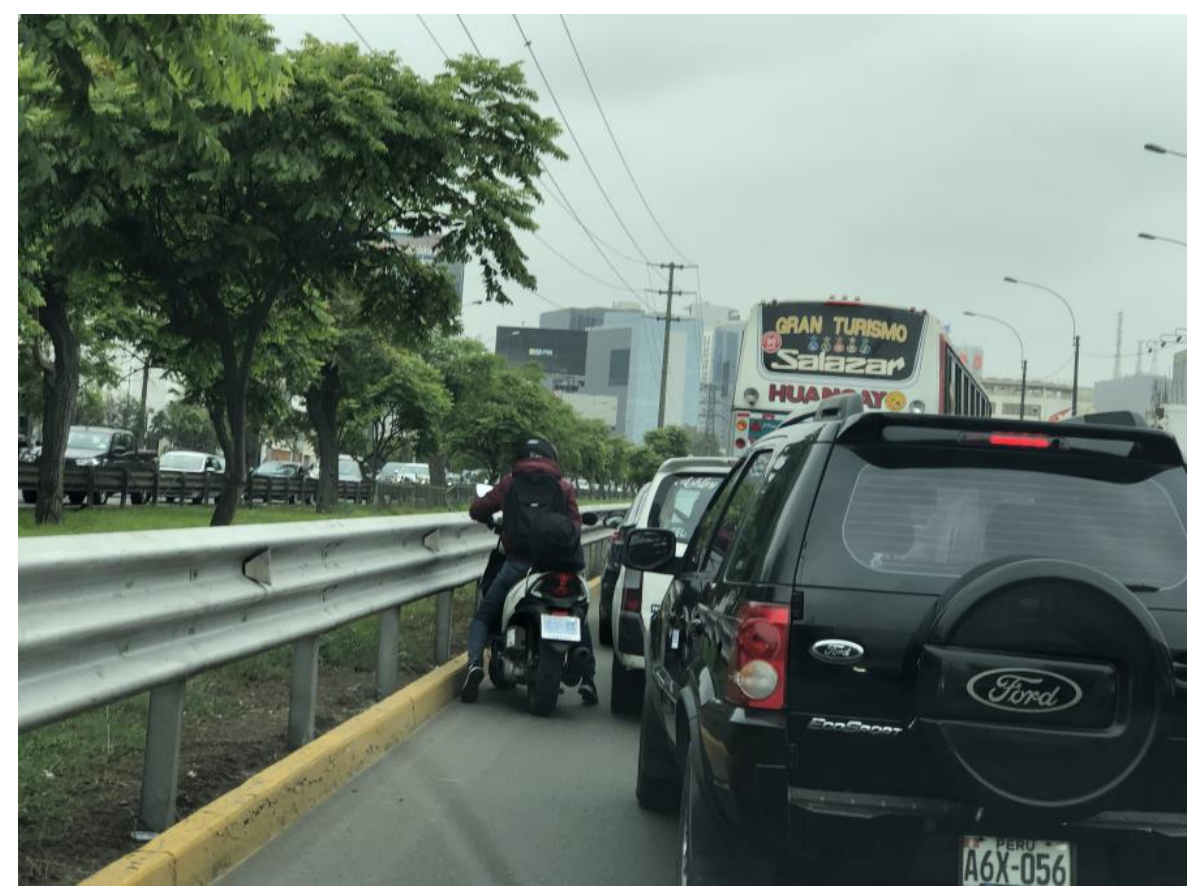

Foto 2.1. Motociclista que no respeta los carriles designados en la avenida Javier Prado. Fuente: Propia

En una encuesta realizada a 50 conductores de la ciudad de Lima se obtuvo como resultado que el estrés era uno de los factores principales que conllevaban a la frustración, impotencia y agresividad en algunos casos. Un 68\% calificaba como estresante el tiempo que 
destinaban a conducir hacia sus centros de trabajo y estudio, a su vez, un $76 \%$ contestó que el tráfico y la congestión vehicular había llegado a alterarlos en más de una ocasión, generando que hayan gritado e insultado a otros conductores y peatones o incluso a cometer maniobras riesgosas con sus autos. A pesar de ello, la gran mayoría respondió que estaban conscientes de los peligros que ello representaba tanto para ellos mismos como para los demás, sin embargo, la frustración y la ansiedad generan respuestas de agresividad en la mayoría de encuestados.

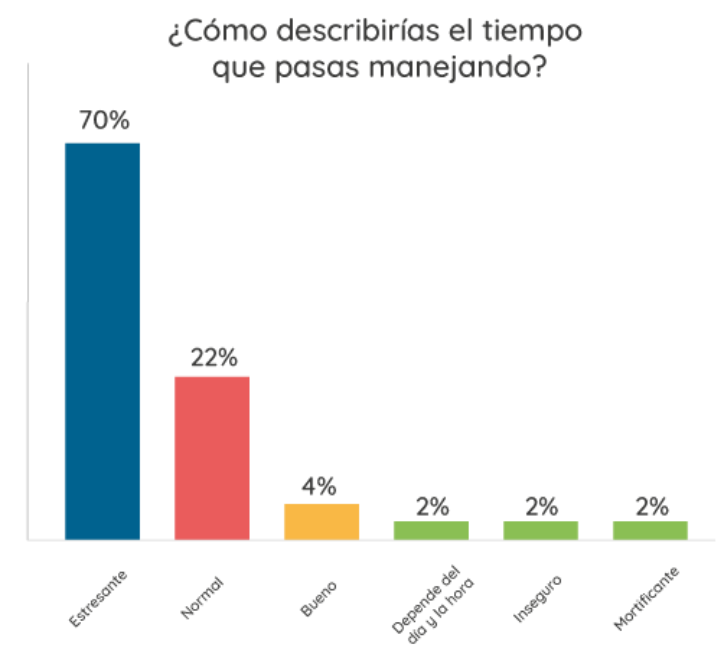

Cuadro 2.1. Tabla estadística con resultados de la pregunta 8 de las encuestas realizadas a 50 conductores limeños.

Fuente: Propia

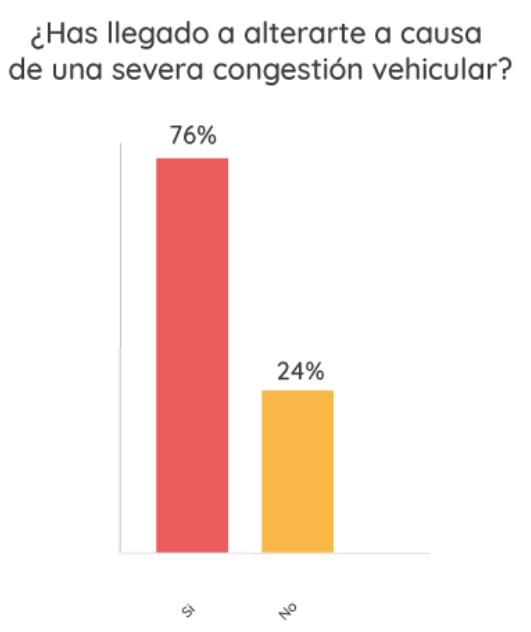

Cuadro 2.2. Tabla estadística con resultados de la pregunta 3 de las encuestas realizadas a 50 conductores limeños.

Fuente: Propia 


\subsubsection{Tránsito en Lima}

La velocidad promedio de un vehículo en Lima es de aproximadamente de 14 kilómetros por hora, siendo una de las más bajas de la región sudamericana, lo que demuestra que la vialidad en la capital necesita una renovación (Vílchez, 2017). El parque automotor de Lima es de 1.8 millones de automóviles que colapsan el actual sistema de tránsito; si comparamos estas cifras con las de la ciudad de Sao Paulo en Brasil, donde circulan alrededor de 8 millones de autos a una velocidad promedio de 26 kilómetros por hora (Mozo Sánchez, 2012), se hacen evidentes las deficiencias en la vialidad de Lima.

La ciudad de Lima, al igual que otras ciudades del país, ha crecido en los últimos sesenta años debido a una explosión demográfica y un fenómeno de migración (Maskrey \& Romero, 1986), a consecuencia de ello, la ciudad jamás estuvo diseñada para albergar tal cantidad de habitantes. Lima se ha extendido de forma horizontal mas no vertical, sin ninguna planificación urbanística; no obstante, lo que han hecho otras ciudades para combatir este problema es mejorar el transporte público, evitando así el uso desproporcionado de vehículos particulares. Sin embargo, Lima tiene un atraso considerable en este aspecto. Desde los años noventa hasta la actualidad, la gran mayoría de empresas que prestan el servicio de transporte urbano son empresas afiliadoras, es decir, no son propietarias de las unidades vehiculares. Es debido a ello que no tienen un poder real sobre el conductor ni sobre el vehículo, esta es una de las principales razones por las que se genera el desorden en el tránsito vehicular limeño.

Hoy en día, existen nuevos servicios como el Metropolitano, el tren y rutas de buses, que son brindados por la municipalidad y el gobierno central, pero sigue siendo insuficiente para el número de usuarios diarios que usan este tipo de transporte. Algunos expertos dieron como posible solución inmediata una propuesta llamada Pico y Placa, la cual trata de evitar la 
circulación diaria de vehículos en determinadas zonas en base al número de su placa. Según estudios (El Comercio, 2016) un 71\% de limeños estarían de acuerdo con esta medida, que puede parecer una medida de contención en vez de solución, pero que ha tenido resultados en México, Chile y Colombia, no obstante, esta medida solo estaría cubriendo parte del problema. En lo que se refiere a vialidad, existen algunos proyectos que por ahora no han sido desarrollados, como un tramo que conectará diferentes distritos como Barranco y San Juan de Miraflores y que, de concretarse, permitirá la circulación de 75000 vehículos (La República, 2014), generando un mejor flujo en las autopistas. Este problema de tráfico y tránsito no solo se traduce en horas perdidas y vías colapsadas, sino que tiene consecuencias realmente graves, en el Perú se evidencia a diario un caos vehicular en el tránsito, el cual desemboca en accidentes, en los últimos 12 años han fallecido cerca de 42.600 personas y todos los días ocurren por lo menos 10 accidentes fatales, de los cuales 5 suceden en la ciudad de Lima (Perú 21, 2016).

Si bien la verdadera solución debería estar basada en infundir una buena educación vial para todos los conductores, existe un tema burocrático que da paso a complicaciones en este proceso, pues existen 10 autoridades competentes en tránsito y transporte, cuando en realidad bastaría con una sola que tenga el control general y que las demás autoridades estén alineadas a esta, para poner orden al caos vehicular existente. A más autoridades, mayor riesgo de corrupción; en nuestro país se pueden llegar a emitir más de 500 licencias falsas al mes y la superintendencia de transporte terrestre, SUTRAN, ha clausurado 160 escuelas de manejo, responsables de haber entregado más de un millón de certificados falsos (SUTRAN, 2014). Mientras todo el problema de tránsito ilegal se solventa, el ciudadano común sigue esperando la línea 12 del metro de Lima, la cual sería la única gran solución de transporte masivo para la ciudad y que apenas ha avanzado un 15\% según la Contraloría de la República (Vílchez, 2017). 


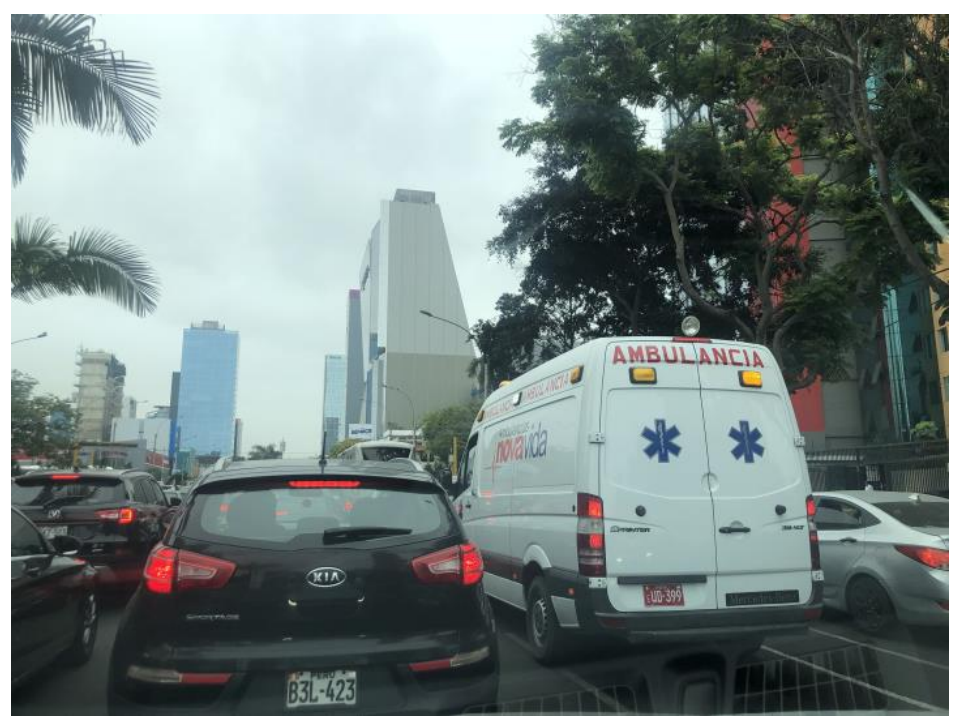

Foto 2.2. Ambulancia estancada en el tráfico matutino en la Av. Javier Prado. Fuente: Propia

\subsubsection{Transporte formal}

En la década de 1940 existió el Servicio Municipal de Transportes que posteriormente sería Enatru Perú, una empresa de transportes que ofrecía un servicio de calidad, con choferes capacitados en Alemania y técnicas europeas innovadoras como el concepto de un chofer cobrador (Alfaro \& Saavedra, 2008). Con el pasar de los años, la empresa fue prosperando; sin embargo, es durante el primer gobierno de Alan García, que empieza la decadencia de Enatru, uno de los principales problemas fue el terrorismo, debido a que muchas unidades fueron incendiadas y destruidas, lo que hacía difícil que el Estado pudiese darse abasto para poder permitirse nuevas unidades y repuestos, es por ello que la empresa cierra. Maza (2002) indica que:

Para el año 1991, el congreso aprueba el decreto legislativo 651, que intentaba promover la libre competencia y tarifas en el transporte urbano e interurbano, con ello, lo que se hizo fue declarar el libre acceso a las rutas de servicio de transporte público, luego en 1992, el gobierno con la ley 25789 derogó las disposiciones que prohibían o restringían la 
importación de bienes usados, entre ellos los vehículos, de esta forma los buses, camionetas rurales (también conocidas como combis) y autos usados en otros países, principalmente de Japón, llegaron a Perú. (p.99)

Se creyó en un principio que estas combis servirían como un medio transitorio de ayuda, debido a la poca demanda de buses existente en el momento, no obstante, es evidente que esta teoría fracasó y de manera descontrolada, miles de micros, buses y automóviles que no se encontraban en perfecto estado, ya estaban en circulación por la ciudad, incluso, muchos automóviles lo continúan haciendo hasta el día de hoy. El primer paso para ordenar el transporte en Lima llegó en el 2005, el plan maestro de transporte urbano fue una radiografía real y moderna de los hábitos y necesidades de los usuarios para así plantear soluciones concretas. Entre las propuestas a corto plazo, figuraba la implementación de un sistema troncal alimentador de buses, un servicio de tren que cubra la ruta San Juan de Lurigancho - Villa El Salvador y una mejora en la administración de tránsito, ya sean pistas, semáforos, educación vial, entre otros. Demoró en implementarse, pero en el año 2006, durante el segundo periodo de Luis Castañeda en la Municipalidad de Lima, el metropolitano se hizo realidad. Este nuevo sistema de buses prometía conectar 17 distritos en tiempo récord. Tras 25 años de larga espera, en el 2011 los limeños vieron culminadas las obras del metro de Lima, sistema que prometía traslados con rapidez y comodidad a sus usuarios frente al incremento de vehículos en las calles. En julio de 2011, Susana Villarán ejecutó las primeras acciones del plan de reordenamiento en Lima, eliminando las combis que circulaban por la avenida Arequipa y se reemplazaron por los vehículos del corredor azul, nueve años después, Lima cuenta con 5 corredores en las principales vías de la capital. Pese a la implementación de estos servicios para facilitar el transporte en Lima, 
el problema no ha terminado, pues no llega a cubrir la demanda y necesidades de los usuarios, a pesar de contar con distintas unidades de transporte adicional, los choferes de los transportes informales aún siguen siendo los principales responsables de los accidentes de tránsito y el caos vehicular.

\subsubsection{Transporte informal}

Durante el primer gobierno de Alberto Fujimori, se generaron diversas políticas para permitir la importación de vehículos de segunda mano, esto conllevó a que se diera paso a una mayor libertad para la competencia en el sector del transporte público, lo que incentivó las prácticas negativas, como es el caso de las formas arriesgadas de conducción de los choferes, la utilización intensiva de flotas y la constante alza de tarifas (Villagómez, 2002). Finalmente, a partir de 1991, el estado dejó de gestionar el transporte limeño, dejándolo así en manos privadas. De pronto, surge un problema que contrarresta la ascendente importancia del transporte limeño, se implementa una nueva flota de vehículos usados que no respondía ni a un orden técnico, ambiental ni mucho menos económico.

Asimismo, la evolución de este problema se estaba saliendo del control del gobierno y existieron intereses privados de por medio que no fueron controlados, de hecho, hubo una adecuación a normas de parte de las empresas involucradas y el concepto de servicios quedo relegado. La informalidad del servicio era muy evidente, pues contaban con rutas mal planificadas e improvisadas, incumplían con las normas de tránsito, no se entregaban boletos, no había derechos laborales, entre muchos otros. (Salazar \& Acha, 2009, p.35)

Por otro lado, la incomodidad del usuario se representa en la arriesgada manera de conducir, lo que ocasionaba inseguridad, causando siniestros y accidentes, asimismo, también se 
generó un incremento en la congestión vehicular, superpoblación de líneas de buses y un exceso de utilización de recursos como paraderos y pistas. En la actualidad es común escuchar a la población decir que la manera en que los choferes conducen es el principal causante de la congestión y el desorden característico del tránsito de la ciudad. Muchas de las pistas de Lima y Callao están plagadas de conductores que día a día ignoran las señales de tránsito, siendo responsables de atropellos, choques, fugas, embotellamientos e incluso agresión hacia las autoridades (Wong \& Gutiérrez, 2010). Suele afirmarse que dicha manera de conducir se debe a una falta de educación y a una naturaleza agresiva propia de los transportistas, de esta manera, ellos hacen uso de algunas prácticas y tácticas informales en el transporte público actual, algunas de ellas son estancarse, que consiste en quedarse en una esquina o en un semáforo por varios minutos, incluso pueden ignorar varias luces verdes, perjudicando a quienes estén detrás con tal de obtener un mayor número de pasajeros.

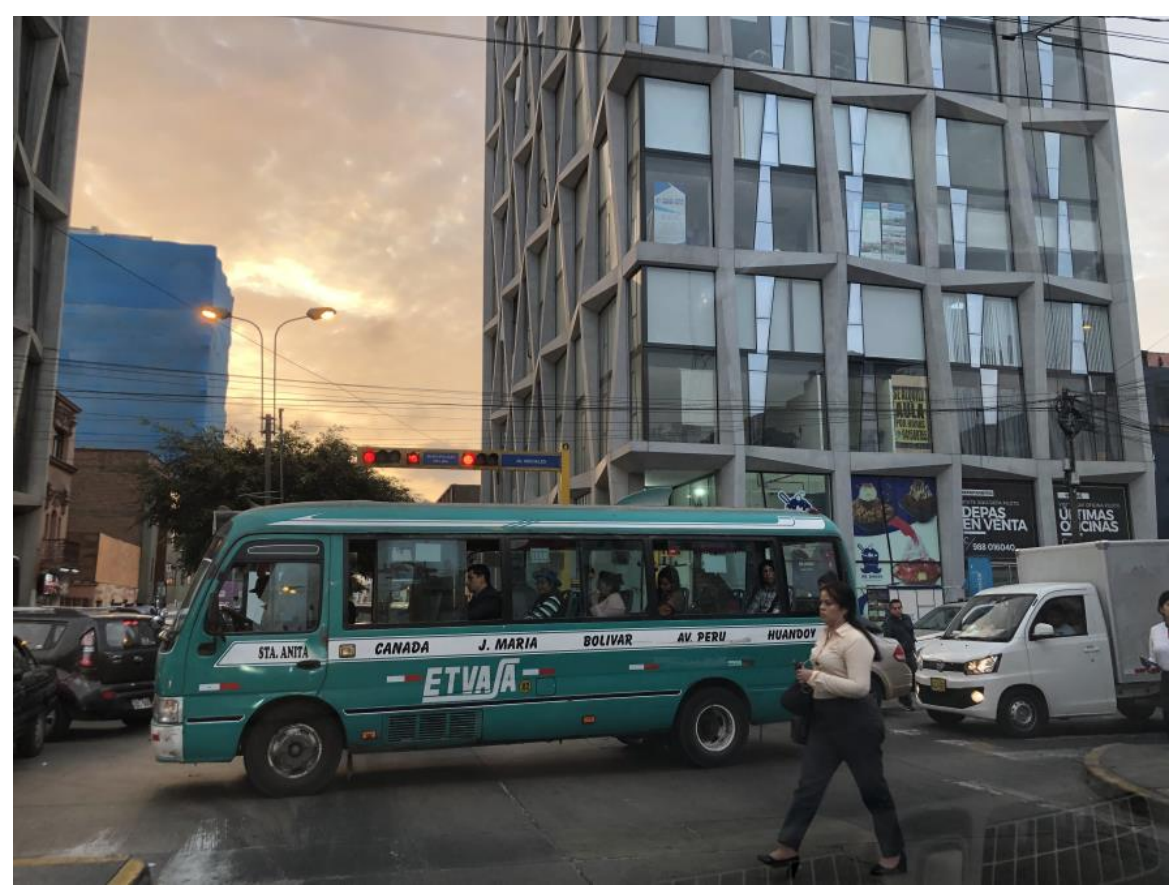

Foto 2.3. Autobús obstruyendo intersección en Av. Arenales (cuadra 14). Fuente: Propia 
También existe la técnica de "correteo" que como su nombre indica consiste en conducir de manera muy rápida, casi siempre sobrepasando los límites de velocidad, esto ocurre cuando dos o más unidades compiten por potenciales usuarios, lo que pone en riesgo la vida de todos. Por último, existe el "urbaneo", táctica que implica no cumplir con las rutas establecidas y desalojar a los pasajeros cada cierta cantidad de paraderos, de tal manera que evitan que estos mismos viajen la ruta completa para así obtener mayores ganancias (Vicuña \& Rojas, 2014). Por lo mencionado anteriormente, el tema del transporte público no puede ser dejado de lado por las autoridades ni los medios de comunicación.

\subsubsection{Lima ciudad del caos}

La municipalidad de Lima en el año 2015 decidió prorrogar las autorizaciones de las empresas informales o aquellas que apenas cumplen con los requerimientos mínimos por 3 años más, incluyendo una extensión de 18 meses, por lo que la ciudad tiene que convivir con numerosas flotas de vehículos de naturaleza precaria y deudora que atentan contra la seguridad de las personas hasta finales del año 2019. Lo anteriormente mencionado fue parte de haber desmantelado todo un proceso de licitaciones y concesiones de la ciudad de Lima (Vílchez, 2017). En la actualidad, ya no debería de haber combis en las principales vías de la ciudad, sino un único sistema de transporte integrado como el metropolitano y el servicio de corredores, con un sistema de recaudo que no solamente consista en la recolección del dinero, sino que también permita regular de manera centralizada la circulación de las unidades para que la gente pueda saber a qué hora llegan los vehículos. 


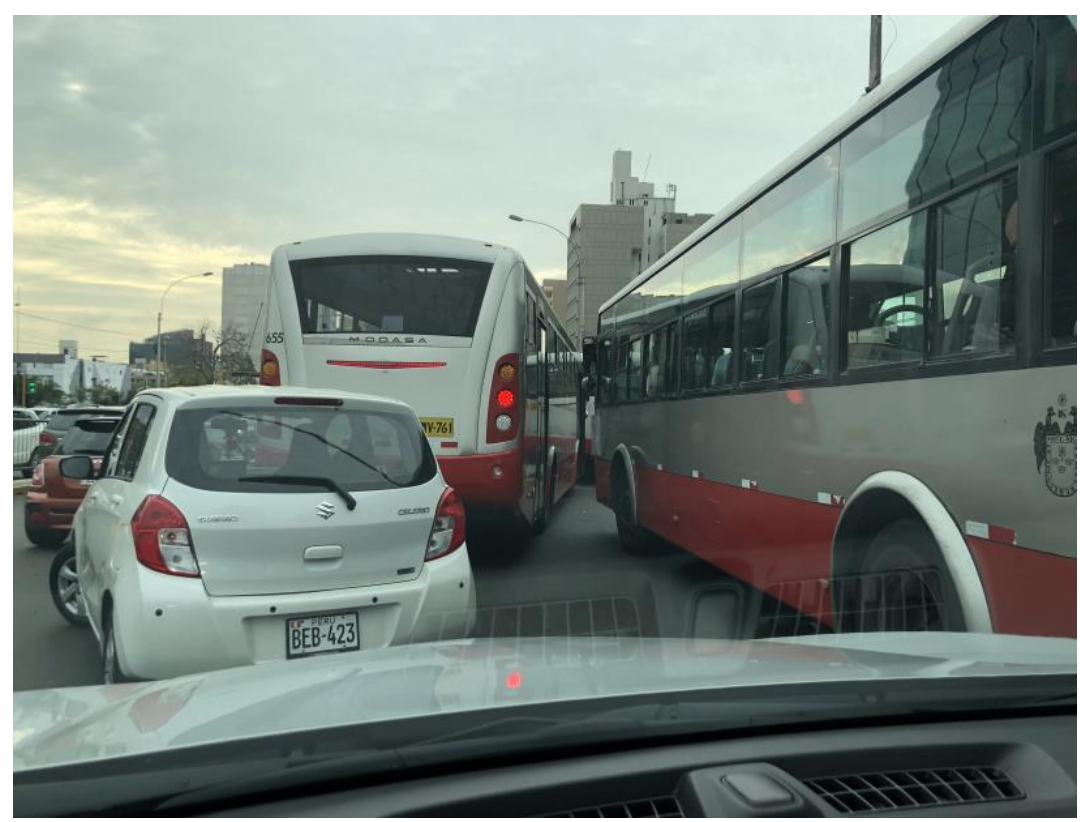

Foto 2.4. Buses de transporte público y autos particulares esquivándose entre sí y traspasando los carriles designados de manera imprudente.

Fuente: Propia

El SAT es quien administra los depósitos, aunque la gerencia de transporte urbano y el SAT forman parte de la municipalidad, sus intereses no están alineados (Bambarén \& Chú, 2013). El segundo se encarga de recaudar y para ello, es más eficiente confiscar vehículos con deudas que puedan ser razonables de pagar por el dueño, a confiscar vehículos que posean deudas muy elevadas, pues si esta unidad fuera llevada al depósito, lo más probable es que el dueño decida no querer recuperar el vehículo al ser una suma muy grande, ocasionando que se ocupe un espacio en el depósito indefinidamente, es por ello que muchas veces se ve cómo vehículos regresan a las calles rápidamente tras haber sido confiscados, esto permite al SAT seguir recaudando e incrementando la bolsa de la municipalidad de Lima. Por otro lado, Figueroa (2005) indica que:

Los operadores que son titulares de una concesión han pasado por un proceso de selección para poder hacerse cargo de la operación de una ruta, en retorno, se espera un determinado número de ganancias que les permitan cumplir con las obligaciones de 
renovación de flota, asimismo, utilizan vehículos de dimensiones grandes con tecnologías más limpias y eficientes. (p.57)

Sin embargo, los conductores de colectivos informales les quitan a estas empresas parte de las ganancias legítimas que deberían estar percibiendo para cumplir con las obligaciones estipuladas. Esto también afecta a los usuarios y demás conductores, pues generan congestión, contaminación, accidentes e incrementan la inseguridad ciudadana.

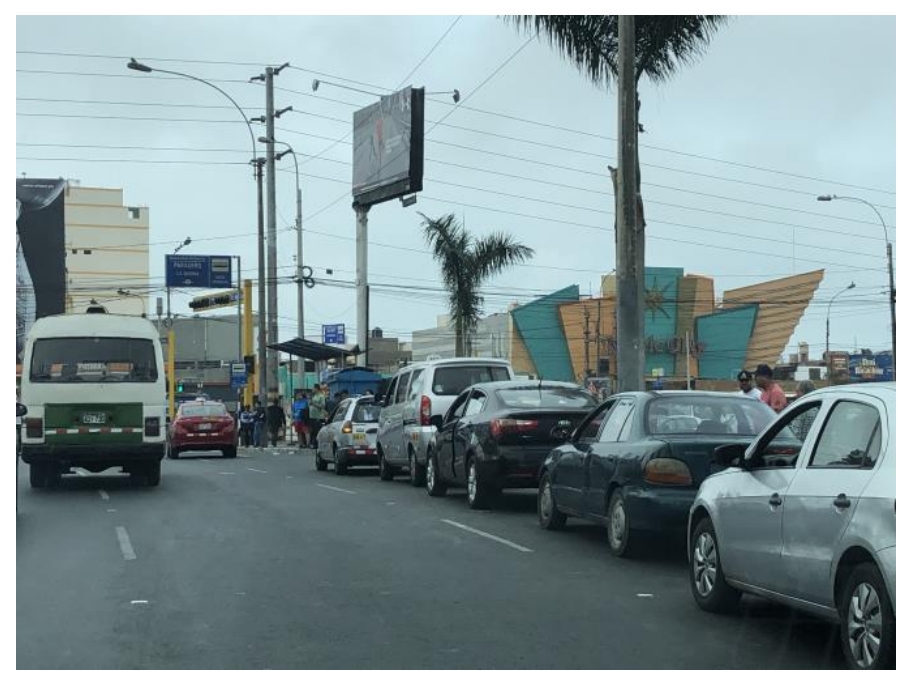

Foto 2.5. Taxis y colectivos informales obstruyendo el paso para poder recoger pasajeros en la avenida Universitaria.

Fuente: Propia.

Lo que las autoridades tienen que hacer es priorizar y privilegiar la macro transportación en transporte público, entendidos como vehículos más grandes, menos contaminantes y que además respeten las normas y los límites de velocidad, que cuenten con una operación centralizada, con conductores que estén en planilla.

Por otro lado, otro problema que genera caos vehicular son las motos que hacen servicio de delivery por medio de diversos aplicativos móviles, ya que no están regulados ni tampoco existen leyes debido a lo reciente de su aparición. Los conductores de estos aplicativos suelen utilizar motos debido a la facilidad con la que pueden evitar la congestión vehicular, sin 
embargo, manejan de manera imprudente y muchas veces corren el riesgo de generar accidentes de tránsito.

\subsubsection{Violencia vial en Lima}

El caos vehicular impera en las calles de Lima y es en este escenario que los taxis colectivos poco a poco se han posicionado como la alternativa ilegal a demanda de transporte público que existe en la capital. A diario se realizan 16 millones de viajes en Lima, de los cuales, solo 1 millón son cubiertos por el Metropolitano, el tren y los corredores, el resto de usuarios los realizan bajo un transporte ilegal como el servicio de colectivos (Arias \& Valdiviezo, 2014).

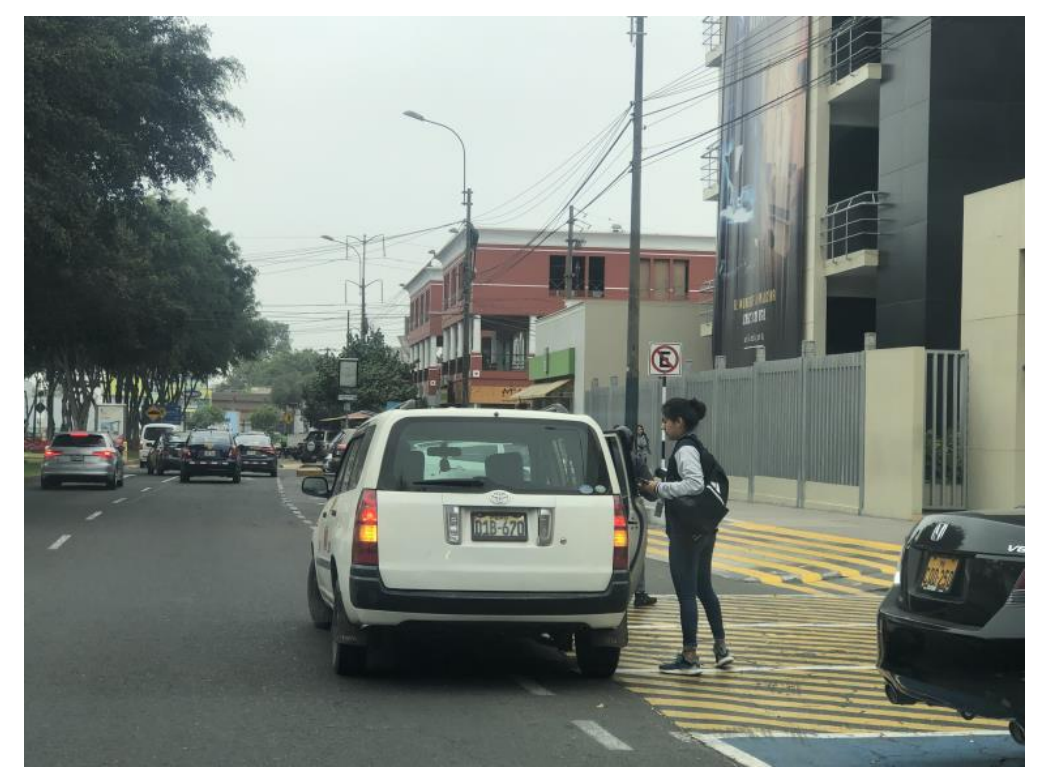

Foto 2.6. Taxi informal recogiendo un pasajero en una zona de estacionamiento prohibido. Fuente: Propia.

El parque automotor pasó de 450 mil vehículos a 1 millón 800 mil circulando solo en la capital peruana, esto ocurrió en las dos últimas décadas sin una planificación urbanística ni desarrollo de la infraestructura vial (Perú 21, 2016). Según Luis Quispe, director de la ONG Luz Ámbar, la pérdida de horas hombre está estimada en mil millones de dólares al año debido a las 
horas que los ciudadanos pasan en el tráfico, estimando aproximadamente entre 3 y 4 horas. Uno de los efectos más preocupantes del caos vehicular es el grado de estrés que se viene generando en toda la población, según coinciden varios estudios académicos y especialistas. En casos extremos, la anarquía se impone en las calles, como fue el caso de Manuel Liendo Razuri, quien en el año 2018 fue grabado por otro conductor mientras se encontraban atrapados en el tráfico, este al ser increpado por haber cometido un acto de imprudencia procedió a mostrar un arma de fuego y amenazar con disparar.

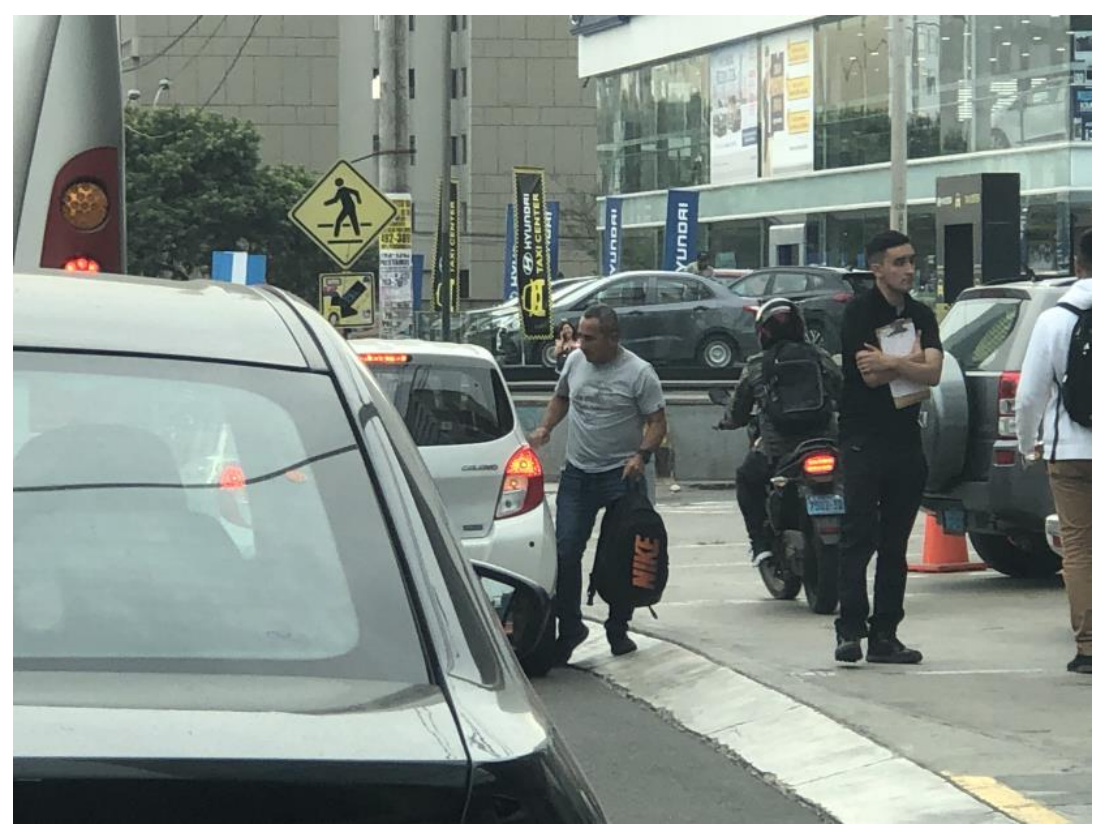

Foto 2.7. Colectivo informal recogiendo pasajeros y obstruyendo el tránsito. Fuente: Propia.

Según el sociólogo Carlos Bejarano, Lima se ha convertido en una ciudad muy complicada para vivir, debido al mal humor e incomodidad que se percibe en el día a día de las personas, generando estas situaciones de violencia y agresión (El Comercio, 2016). Para los conductores y peatones peruanos, el estrés diario es una de los causantes principales de accidentes de tránsito, en base a las encuestas realizadas para esta investigación, un 78\% respondió que la sensación de impotencia y temor frente a tantas infracciones diarias sin ser 
penadas hacen que las personas pierdan la calma rápidamente, lo que ocasiona actos de violencia tanto verbal y física, como sucedió en el caso de dos conductores en el distrito de Miraflores, uno de ellos apuñaló a otro por el hecho de haberle cerrado el paso con su vehículo. La gresca habría empezado desde mucho antes con insultos e improperios desde los vehículos, sin embargo, terminó en muerte. Sin duda el caos vehicular no solo genera congestión y malestar en los ciudadanos, pues con los casos mencionados anteriormente, se puede apreciar como ocasiona problemas mucho mayores en donde la vida de todos está en riesgo.

\subsubsection{Desde el punto de vista del conductor}

Tres mil personas mueren al año en las pistas del Perú, una cruda cifra que tiene como una de sus causas los excesivos beneficios de los que goza un infractor del reglamento nacional de tránsito. Los altos descuentos en las papeletas es uno de ellos.

Lima es la única capital de América latina que otorga un descuento de hasta el 83\% en la deuda de una multa. Si bien es cierto este descuento no se aplica para las infracciones M01 que es conducir en estado de ebriedad y la infracción M03 que es conducir sin licencia, hay altos descuentos para aquellas que son muy graves como circular sin SOAT, manejar sin cinturón de seguridad, conducir sin placa de rodaje o con brevete vencido. (Wong \& Gutiérrez, 2010, p.176)

Para el periodista Juan Pablo León Almenara, las leyes están hechas para beneficiar al mal conductor, lo que quiere decir que el infractor siempre gana. Por ejemplo, si un conductor no respeta el Pico y Placa debería de pagar S/.336, sin embargo, al momento de incluir el descuento, termina siendo S/.57.

Este tipo de descuentos sí existen en otras ciudades del continente, pero la diferencia es que estos se aplican solo para las faltas leves y nunca llegan a ser mayores al 50\% del monto. 
Además de los descuentos, los malos conductores gozan de numerosos vacíos legales que les permiten iniciar procesos por 4 años hasta que prescriba la deuda, asimismo, hay abogados que recomiendan estas prácticas para aprovecharse del sistema y hacer que estos pagos jamás se realicen; además, las amnistías distritales y provinciales permiten obtener hasta el $90 \%$ de descuento en la multa, sin siquiera considerar la gravedad de la infracción (Bambarén \& Chú, 2013). Como ya se ha mencionado anteriormente, uno de los principales responsables de que exista este problema es el SAT, pues los intereses de esta organización están enfocados en recaudar, por ende, le conviene que en los depósitos haya una recirculación de vehículos para que así el flujo sea constante y la bolsa de la Municipalidad de Lima incremente.

Para el especialista en temas de transporte, Lino De la Barrera, no solamente se trata de una inexistencia de leyes sancionadoras, sino que el problema pasa por una mala gestión que termina otorgándole impunidad a los infractores. Muchas veces, lo que falla no es que se disminuya el pago, sea este grande o pequeño, sino el hecho de que se imponga, que exista la posibilidad de detección de la persona que está infringiendo la ley y que la sanción que se aplique sea eficiente. En ese sentido, el Ministerio de Transportes y Comunicaciones anunció a fines de junio del año 2019 que viene desarrollando un sistema que permitirá notificar automáticamente al infractor y acelerar el proceso de sanción para evitar que los malos conductores se acojan excesivos beneficios.

\subsubsection{Desde el punto de vista del peatón}

"La imprudencia, el desorden, el caos y el estrés son los elementos característicos del transporte público y privado de la capital que diariamente afecta a choferes, pero también a los peatones" (Arias \& Valdiviezo, 2014, p.43). Muchas veces, los peatones son quienes también cometen infracciones y diversas acciones de imprudencia por no perder su bus y llegar tarde al trabajo, 
aunque esto signifique poner sus vidas en peligro. Los peatones suelen tener responsabilidad en el caos vehicular al ser ellos los principales usuarios de los servicios de transporte informales como buses y colectivos, con frecuencia subiéndose a ellos en paraderos no autorizados e improvisados, generando así una mayor congestión vehicular y aumentando los niveles de estrés en los demás conductores y peatones que sí respetan las leyes. Muchas veces, las jornadas de estas personas consisten en ir de manera muy incómoda dentro de los vehículos, en donde casi siempre se excede el límite de pasajeros permitidos por la ley, lo que pone en riesgo la vida de todas las personas abordo. Actualmente la saturación de vehículos y la sobrepoblación han ocasionado que siempre haya bastante flujo de personas en las calles, ello conlleva a un caos vehicular que resulta difícil de controlar por parte de las autoridades, a su vez, los peatones pocas veces son sancionados permitiendo que se sigan replicando actos como el de no respetar las luces de los semáforos, caminar entre los carros para poder subirse al transporte público, utilizar servicios de transporte informal entre otros. En el año 2015 hubo diversos casos en el distrito de Ventanilla en donde varios peatones fueron atropellados por no hacer uso de un puente peatonal para poder cruzar la calle de manera segura, la municipalidad de este distrito indicó que a lo largo del año 2018 se registraron 47 accidentes en este punto (Arenas \& Marino, 2016). No obstante, noticias como estas son bastante frecuentes en los programas de televisión, pues el ciudadano limeño tiende a ser muy negligente e imprudente, sin pensar en las consecuencias de sus actos. Muchas veces los peatones piensan que pueden ganarle en velocidad a los vehículos, pero solo ocasionan accidentes.

Por otra parte, no hay una cultura de respeto al peatón, pues muchos conductores no comprenden que este tiene la preferencia al momento de cruzar la calle, lo que resulta muchas 
veces en disputas verbales e incluso físicas, como insultos, gritos y hasta se dan casos en que peatones indignados golpean los carros de aquellos choferes que casi los atropellan.

\subsubsection{El video}

Desde tiempos primitivos, incluso cuando no se había descubierto la escritura, el hombre ha pretendido representar su realidad, el arte rupestre de las cuevas de Altamira destaca no solo por su antigüedad, sino por la representación de un mundo que no es estático. El pintor trazaba jabalíes con 8 patas tratando de captar el movimiento, así ensaya una nueva dimensión, porque la realidad es cambiante y dinámica, el pintor primitivo lo entiende y trata de plasmarlo en lo que llamaremos una pintura con vocación cinematográfica (Cannone, 2016). Otras representaciones han registrado diversas escenas sucesivas, La Vida de Cristo pintada por Giotto o el Martirio de San Mauricio del Greco repiten personajes mediante viñetas, todas narran una historia a través de equivalentes a escena o planos que son unidades de lenguaje cinematográfico. El movimiento se logra capturar mejor mediante el uso de sombras chinescas, que generaban movimiento mediante la sombra de las manos, esto originó el teatro de sombras (Sánchez Noriega, 2016). La linterna mágica o linterna terrorífica les da un tono sobrenatural a los precedentes del cine, se proyectaba la imagen con una botella de aceite que emitía luz, después de esto, la ciencia participaría en este proceso. Fernández (2016) indica que:

El precedente más claro del cine como invento tal como ahora se le conoce es la fotografía, Niépce al tratar de mejorar la litografía logró obtener mediante la cámara oscura la primera fotografía con una exposición de 8 horas en 1826; posteriormente, Daguerre perfeccionaría el invento y la redujo a treinta minutos, llamándolo Daguerrotipo. (p.112) 
A partir de la tesis de Roget en 1824 sobre la persistencia retiniana, se concluye que una rápida sucesión de fotos inmóviles proyectadas discontinuamente son percibidas por el espectador como un movimiento continuado, con este nuevo conocimiento nace el fenaquistiscopio del cual derivaron el fantascopio, el zoótropo o el estroboscopio, de esta manera, se obtuvo los presupuestos del cine como invento. La fotografía sería la materia prima y el principio de la inercia visual que permite crear la ilusión del movimiento.

Del afán de capturar el movimiento mediante la fotografía, se crea la cronofotografía gracias al revolver astronómico en 1874 y posteriormente se estudió el movimiento de los animales mediante una especie de rifle fotográfico (Cannone, 2016). Sin embargo, fue Muybridge quien obtiene la primera descomposición del movimiento, Vela (2019) explica que:

Esto fue gracias al encargo de Standford a causa de una apuesta para saber si un caballo podría sostenerse en una sola pata mientras galopa, posteriormente al unir estas fotografías en secuencia, se generaba la ilusión de un caballo en pleno trote. (p.21) Sin embargo, faltaba conseguir la síntesis del movimiento mediante la proyección sucesiva de dichas fotografías sobre una pantalla, Reynaud perfeccionó el zoótropo mediante un tambor de espejos, consiguió proyectar sus imágenes pintadas por reflexión sobre una pantalla, exhibió su teatro óptico utilizando bandas dibujadas y coloreadas por él mismo y en 1892 inició la proyección sobre pantalla de sus pantomimas luminosas, a él se le atribuye ser el padre de los dibujos animados.

Fue Edison, quien aportó con las películas de celuloide con perforaciones para su arrastre, además consiguió proyectarla con el quinetoscopio, el cual servía para que una sola persona viera las imágenes almacenadas en 14 metros de película, su mecanismo se basaba en hacer girar una manivela para deslizar las imágenes y es un gran precedente del nuevo invento (Fernández, 
2019). Muchos contribuyeron para llegar a crear el cine, así que se puede afirmar que fue una inversión colectiva, pero los historiadores se ponen de acuerdo en que fueron los hermanos Lumière quienes sintetizan todo lo avanzado. Su invento proyectó las imágenes en una amplia pantalla y funcionaba accionado por una manivela que arrastraba la película a la cadencia de 16 imágenes por segundo que después serían 24. Servía para filmar y proyectar imágenes en movimiento y fue llamado cinematógrafo, de esa manera se crea el video.

\subsubsection{Tipos de video}

El video está normalmente categorizado según la extensión del mismo; un largometraje está comprendido en historias que sobrepasan los 30 minutos hasta 2 horas mientras que el cortometraje son aquellos productos cinematográficos que poseen una duración de media hora o menos (Hernández \& Carmen, 2019). En su sentido más práctico, consiste en relatar una historia de manera completa que puede hablar de temas tanto reales como ficticios, en el caso de un cortometraje, es importante que la historia sea completa y que sea contada en un breve rango de tiempo, asimismo, permite al espectador atravesar por una especie de catarsis respecto a los contenidos presentados. Todos los elementos involucrados, como el sonido, la música e inclusive los subtítulos permiten hacer que el espectador entienda la historia de manera completa.

Existe un estándar que se suele utilizar como base en diversos concursos en donde el máximo de duración no debe de ser de más de 10 minutos. Es importante tener muy claro que el video puede llegar a tener el mismo impacto al estar tanto en cortometraje como en un largometraje, ya que el formato de guion para ambos suele ser exactamente el mismo, en donde se encuentran elementos como el contexto del lugar, descripción del entorno, las acciones de los personajes, los diálogos y las transiciones de escena a escena (Pelliccia, 2017). En cuanto al lenguaje y a la narrativa si se pueden encontrar algunas diferencias, aunque es cierto que un 
guion de un corto posee tres actos, la mayoría de cineastas los realizan en un nivel más experimental, en donde se utiliza un factor sorpresa que en una película suele ser más complicado de mantener, lo anterior ayuda a que la narrativa sea más interesante y sorpresiva, haciendo que el espectador no tenga oportunidad de distraerse frente al discurso que se está contando. Otra diferencia es que, en muchos cortos, la historia suele girar entorno a un solo personaje mientras que en un largometraje hay mucho más tiempo para poder desarrollar no solo al personaje principal sino también a personajes secundarios que acompañan al protagonista, ayudando a dar información y profundidad a la narrativa.

\subsubsection{Diseño visual}

“El diseño visual identifica las necesidades de comunicación de determinado público y a través de la planeación estratégica deduce cual es la opción más viable; implica creatividad, disciplina y una alta capacidad de interpretación para que la comunicación sea efectiva”. (Scolari, 2018, p.67) Consiste en crear sistemas de información visual entre el cliente y el público a través de los cuatro núcleos comprendidos en esta rama del diseño, los cuales apuntan a todas las áreas donde la comunicación debe de estar presente, estos núcleos son la imagen fija, digital, ambiental y la imagen móvil.

Lo particular del último núcleo mencionado es que aplica conocimientos de diversas ramas como la fotografía, el video y animación entre otros. El diseño visual puede ser encontrado dentro de cortos y largometrajes, de igual manera, se desarrollan conceptos de animación y post producción, aportando así todos los conocimientos adquiridos en composición y creación de sistemas visuales, asimismo, el diseño visual no solo se basa en procesos creativos, sino también en procesos donde la investigación es un elemento primordial, por ejemplo, en 
trabajos interdisciplinarios para llegar a la ejecución de sistemas visuales como una valla publicitaria, dispositivos móviles o señales para los invidentes. Arce (2016) afirma que:

La creación de interfaces es vital en todo trabajo del diseñador, debido a que genera diversos métodos comunicacionales, dichas interfaces deben de hacer analogías con objetos o conceptos conocidos, por ejemplos, una página web informativa a un periódico o una tablet digital a una libreta. (p.62)

El diseñador se convierte en un mediador entre el usuario y sus necesidades, las cuales pueden ser comunicativas como el chat, informativas como la web, comerciales como las tiendas online hasta experiencias inmersas como los videojuegos y la realidad aumentada; otra tarea importante es estructurar y filtrar información de una manera clara y comprensible, lo que quiere decir que una persona de cualquier edad y contexto pueda navegar fácilmente por estas interfaces. Es necesario saber lo que se va a comunicar, ya sea información o una experiencia, se debe de conocer la intención de cada interface o quién va a ser el objetivo de la misma, con qué recursos se cuenta, ya sea video, fotografía, gráficos, ilustraciones, audio o cualquier otro medio. Se debe de tener en cuenta qué nivel de interacción se va a realizar, si será solo la exploración de una página web o si el usuario puede intervenir en la arquitectura de la misma.

El diseño visual facilita los procesos de usos educativos y comerciales, acortando distancias al hacer posible una clase en tiempo real o un intercambio comercial vía internet., por lo que se infiere que este núcleo del diseño funciona a manera de puente entre el cliente y sus necesidades. (Rodríguez-Gutiérrez, 2018, p.12)

En algunas universidades, el diseño visual cuenta con grupos y semilleros de investigación, laboratorios de imagen, maestría en diseño y doctorado para que los estudiantes tenga un pleno conocimientos de todos los procesos involucrados. 


\subsubsection{Diseño de video como herramienta educativa}

Los medios de comunicación y las tecnologías de la información han desempañado un papel fundamental en la configuración de la sociedad y la cultura, en el contexto educativo ha tenido repercusiones en los procesos de aprendizaje de los estudiantes. A través de distintos medios y tecnologías se ha dado una explosión de diversos lenguajes con diversas formas de expresión desde el lenguaje oral, escrito, kinestésico, visual, icónico, sonoro, audiovisual y la convergencia de estos (Vélez, 2018). La comunicación mediada por recursos audiovisuales y multimedia enriquece la actividad sensorial y la posibilidad de hacer significativo el mensaje al receptor.

Los nuevos lenguajes audiovisuales han dado lugar a la cultura de la imagen en movimiento, en la que la escuela, una institución primordialmente oral libresca, tiene la posibilidad de explotar y aplicar el potencial de distintos medios en diversos espacios académicos tanto presenciales como virtuales. "En la historia del lenguaje audiovisual, el video se ha convertido en una herramienta poderosa para difundir información, comunicar, persuadir, aprender y construir la identidad cultural, política o ideológica de los sujetos” (Ortiz, 2019, p.55). En las aulas, el video es un elemento detonador de motivación como mediador en los procesos de aprendizaje, como elemento de análisis de comunicación y de transmisión de la cultura. En los escenarios actuales, el video ha tomado gran relevancia sobretodo entre los jóvenes, quienes a través de distintos medios y dispositivos navegan en los espacios virtuales y comparten imágenes fijas y en movimiento, audio y música; acorde a sus intereses y creatividad, crean y producen video que con un clic comparten en la red por distintos canales y redes sociales. Por ello, el video es un importante apoyo para enriquecer el proceso de enseñanza; sin embargo, su uso no debe de sustituir la tarea del docente, por el contrario, requiere de una 
metodología desarrollada por el mismo para poder guiar a los alumnos en un correcto proceso de aprendizaje. Al utilizar un video es importante que se consideren distintos aspectos como grupo de alumnos y el nivel de escolaridad, el contenido, el objetivo, la estrategia didáctica y con qué dinámicas va a ser complementado (Gómez, 2018). Esta herramienta resulta ser actualmente una de las que más brindan apoyo a los docentes en la educación para realizar un trabajo en conjunto y cumplir las metas establecidas.

El valor educativo del video reside no solo en ser un medio que promueve la comunicación y el aprendizaje, sino también en sus posibilidades de autoría (Vélez, 2018), ya que, como herramienta de autor, permitirá a los profesores, además de utilizar materiales comerciales, desarrollar su propio material multimedia adaptado al contexto de sus estudiantes, con estrategias didácticas que respondan a sus intereses. Para los estudiantes, serán experiencias formativas donde utilizarán una convergencia de medios que van a encontrar en diversos lugares a lo largo de sus vidas profesionales y que forman parte de la cultura tecnológica que se encuentra presente en todos los ámbitos de la sociedad del conocimiento.

\subsubsection{El stop-motion}

Es una técnica de animación que consiste en dotar de movimiento a objetos estáticos mediante una sucesión de cuadros, también conocida como animación cuadro por cuadro, lo que genera una ilusión óptica en el ojo humano creando una sensación de movimiento. Su origen se remonta hasta los orígenes del cine mismo en 1896 y algunos historiadores consideran que el cineasta español Segundo de Chomón fue el padre de esta técnica (Vargas \& Oviedo, 2017). Sin embargo, hay quienes consideran que el crédito también debe otorgársele al francés Georges Méliès quien fue pionero en técnicas que con el tiempo pasarían a ser stop-motion. 
Posteriormente, sería Willis O’Brien, quien desde muy temprana edad empezó a interesarse por la animación realizando pequeños cortos con dinosaurios, pero no sería hasta el año 1933 que realizaría uno de sus proyectos más ambiciosos, King Kong, el cual terminaría por revolucionar la industria del cine, ya que tuvo un impacto masivo, pues muchos espectadores pensaron que se había utilizado un mono entrenado durante la película (Simbaña, 2018). Tras este éxito, la industria cinematográfica posó su mirada en el stop-motion, pues gracias a la infinita posibilidad creativa que permitía esta técnica, muchos realizadores por fin habían encontrado una nueva forma de expresión para poder generar experiencias innovadoras. Para la década de los años 80, el stop-motion fue el predecesor de los efectos especiales generados por computadora, una de las figuras que más destaca por sus aportes fue el animador Ray Harryhausen, quien fue alumno de O'Brien (Farfán, 2016). Llegado el nuevo milenio, el stopmotion permitió abrir un nuevo mundo a la creatividad e imaginación de aquellos cineastas que buscaban contar su historia de forma diferente. A pesar del auge de las películas animadas por computadora, el stop-motion sigue siendo una de las técnicas más respetadas y valoradas por el público en general, filmes como El extraño mundo de Jack o Coraline son algunos ejemplos recientes que demuestran que aún existe bastante demanda.

\subsubsection{Diseño social}

Su concepto está relacionado en diversas ramas dependiendo del contexto en donde sea utilizado, puede estar vinculado al diseño arquitectónico, a la investigación científica y también a la activismo social y político. El diseño social refuta la responsabilidad que el profesional tiene con la sociedad y además pretende extender las dimensiones económicas y sociales del trabajo (Manzini, 2019), lo cual se toma como referencia al pensamiento estratégico para delimitar otro 
concepto, lo que incluye el establecimiento de objetivos y de proyectos para lograr un propósito por parte de los miembros de la comunidad o pueblo.

Está basado en la creación de nuevas plataformas de comunicación que huyen de la simple protesta para buscar soluciones a través del diseño, en donde las intervenciones buscan fomentar la comunicación positiva de interacciones que implican creación de proyectos basados en la creatividad, empatía y sinergia. "La sustentabilidad en todo el proceso de diseño, el estudio de la viabilidad del proyecto y participación en los debates de todo el equipo son algunos de los elementos ligados al diseño social” (Bastidas \& Martínez, 2016, p.101). Asimismo, también es un medio para poder desarrollar el capital humano, pues es aceptado que las sociedades hoy en día son resultado del diseño de las personas y que el pensamiento estratégico tiene como objetivo un caso de estudios en el diseño social.

El diseño social (Vivanco, 2017) es una corriente que empieza con el reconocimiento del valor de lo propio es decir de lo local, hace mas de 14 años que se concibe como un diseño pensado en el otro en la persona que tiene necesidades y problemas que deben de ser resueltos a través del diseño. Mediante el uso de herramientas de la sociología y antropología permite tener un conocimiento mas preciso del público objetivo hacia el cual se va a dirigir. Esto es de suma importancia porque el proceso de conceptualización y de propuestas de mensajes a construir descansan en la investigación previamente hecha y en ese acercamiento que otros métodos no logran. Tener. El diseño social no es regalar el trabajo del diseñador ni ser asistencialista es pensar en lograr un emprendimiento de todo proyecto que se desarrolle, buscando siempre la mejora de la calidad de vida de la sociedad a la que se pertenece. 


\subsubsection{Importancia de la educación vial}

Cuando se habla de educación vial, se refiere a todo aquello que está relacionado con la seguridad de los usuarios de la vía, quienes son los automovilistas, los ciclistas, peatones y motociclistas; asimismo, tiene muchos componentes y es multisectorial porque está vinculada a la salud, educación, institucionalidad y el transporte. La educación vial implica el adquirir conocimientos como ciudadano sobre lo que es una vía pública, tipos, características y partes (García \& Robalino, 2018), asimismo, sobre seguridad vial, normas de circulación, señales de tráfico, accidentes, consecuencias legales, factores de riesgo y primeros auxilios, así como destreza en el comportamiento como peatón y como conductor. Los accidentes, que en ocasiones suelen ser fatales, son una de las principales consecuencias de no poseer una adecuada educación vial (Cortés, 2017) y son considerados un problema de salud pública debido a la gran cantidad de muertes y lesiones que ocasiona, entre las principales causas de los accidentes de tránsito se encuentran manejar con exceso de velocidad, imprudencia del conductor, imprudencia del peatón, conducir en estado de ebriedad, exceso de carga, desacato a las señales de tránsito y fallas mecánicas entre otros. Debido a lo anteriormente mencionado, es importante que todos conozcan y pongan en práctica normas y comportamientos de seguridad vial, para proteger sus propias vidas y las de los demás. Una de sus principales funciones es sensibilizar principalmente a los más jóvenes respecto a lo comportamientos viales para fomentar la convivencia, la tolerancia, la solidaridad, el respeto, la responsabilidad y que favorezcan las relaciones humanas en las vías públicas. 


\subsubsection{Lego}

El origen de esta marca reside en Dinamarca, antes de 1932, Ole Kirk Christiansen era un carpintero sumido en la desgracia ya que su taller se quemó, su esposa falleció y tuvo que sacar adelante a sus 4 hijos, así que con los materiales que había salvado del incendio se dedicó a realizar juguetes de madera que vendía con ayuda de sus hijos (Gonzáles, 2016). Él era muy exigente y en sus primeros meses como juguetero fabricaba patos, aviones y camiones de madera de gran calidad, sin embargo, el número de sus ventas no era muy elevado. Sabía que tenía que darle nombre a la marca, así que juntó las dos primeras letras de Leg y Godt, palabras danesas que significa jugar bien, dando origen a la marca Lego (Olmos Rojas, 2019). En 1946, en una feria, Christiansen encontró un bloque de plástico fabricado por una máquina e inmediatamente lo compró al ver el potencial que tenía para hacer piezas de sus juguetes, a pesar de ello, no abandonó la madera, pero el plástico cambió la forma de realizar sus productos. En 1949, la empresa familiar comienza a fabricar pequeños bloques de plástico con 4 u 8 botones que se podrían conectar, naciendo así los primeros bloques de Lego. Años más tarde, en 1955, comienzan a exportarse a países como Suecia y Alemania debido a su éxito, pero tres años más tarde, Christiansen fallece y su hijo Godtfred continuó al frente de la marca, la que expande con sedes a Francia, Inglaterra, Estados Unidos, Canadá y posteriormente a todo el mundo (Gutiérrez, 2018). Sus productos siguen siendo relevantes en la actualidad debido a que incentivan al usuario a ser creativo y a explorar su imaginación.

\subsubsection{Lego Serious Play}

Es una metodología relativamente reciente que permite mejorar el funcionamiento de las empresas y organizaciones mediante planteamientos estratégicos concretos y estructurados utilizando bloques de Lego, en donde las ideas de los participantes son plasmadas a través de las 
piezas para facilitar la visualización de las mismas, lo que genera un diseño de soluciones en tiempo real. Prieto (2019) explica que:

El proceso consiste en exponer el problema o situación a resolver y cada uno de los miembros construye una estructura, exponiendo su idea y su perspectiva de cómo podría solucionarse esa situación, posteriormente, las ideas de todos los involucrados se complementan y se ponen en una sola estructura. (p.12)

Lo anteriormente mencionado ha hecho que esta metodología resulte bastante atractiva porque quiebra con el molde de una toma de decisiones basada en jerarquía, ya que con Lego Serious Play, (Rojas \& Llamosa, 2016) todos aportan ideas y esto ayuda a obtener soluciones más concretas, específicas y enriquecedoras, creando puentes que permiten llevar al equipo desde un punto inicial a un punto deseado con una solución mucho más sólida. En una entrevista realizada a diversos facilitadores de la metodología Serious Play, Carlos Valenzuela indicó que la creatividad está en su nivel más óptimo para crear soluciones funcionales y la visión se vuelve mucho más clara porque se tienen las ideas sobre la mesa, lo que ayuda a poder hacer reestructuras simples ante diferentes escenarios y poder poner a prueba estas ideas ante situaciones posibles para determinar la efectividad de cada una de ellas. Esta dinámica libera la imaginación y la creatividad de las personas, a su vez que permite una profundización en la comunicación, lo primero está relacionado al uso de las manos como herramienta principal, ya que se crea un proceso que permite acceder a ese conocimiento tácito e implícito que todo individuo posee. Según la respuesta de Rendo Salazar, facilitador certificado en esta metodología, el hecho de que cada participante aporte los conocimientos propios a través de sus modelos le da más capas y matices a las soluciones que se proponen, asimismo, este sistema resulta ser muy versátil, puesto que no solo encaja bastante bien en determinadas aplicaciones 
como lo son el desarrollo de estrategias, construcción de equipos, diseño de productos, organización entre otros, sino también que permite adaptarse a las necesidades específicas de cada cliente. Los talleres se diseñan para atender muchas necesidades, haciendo que emerjan nuevas posibilidades y metodologías (Gutiérrez, 2018), pues a través del juego, las barreras inconscientes que tienen las personas caen y al hacerlo es más sencillo que se comparta una valiosa cantidad de información que permite ampliar la percepción colectiva que facilita la toma de decisiones.

\subsubsection{Lego en películas y videojuegos}

Desde la década de los años 2000, Lego incursionó en el mundo de las películas y los videojuegos; sin embargo, hasta antes del 2014, las animaciones no representaban las físicas del juguete en sí, puesto que existía la tendencia de representar el plástico duro como si fuese mucho más flexible (Drobnitzky, 2017), lo que significaba que los personajes podían articularse y moverse mucho más de lo que se podía en la vida real. Este estilo es típico en la animación por computadora tradicional, como lo que espera al ver un filme de Pixar. Por ejemplo, en los primeros videojuegos, los fondos no están hechos de bloques sino de texturas, las extremidades se arqueaban y los rostros eran una mezcla de efectos que asemejaban las facciones humanas y la geometría de Lego, lo cual no reflejaba un escenario que un usuario pudiese recrear en su hogar (Knop \& Domínguez, 2017). Sin embargo, en el año 2014 se estrena La Película Lego, en donde todo desde el humo, agua, fuego, explosiones, nubes entre otros estaban hechos completamente de piezas de Lego tal y como se pueden encontrar en la vida real. Se respetaron las físicas del producto original, lo que significaba que cada movimiento que se veía en pantalla simulaba el movimiento de cada pieza individual, por ende, las articulaciones o expresiones no se estiraban o doblaban, solo se movían o eran reemplazadas. Las primeras películas de Lego carecían de ese 
nivel de disciplina, por ello, los animadores tenían dificultades con las limitaciones del producto sin darse cuenta de que eran estas mismas limitaciones las que le daban alma a Lego, de esta manera los creadores de esta película vieron las cosas de una manera distinta y se vieron en la necesidad de encontrar soluciones de manera creativa y atractiva (Olmos Rojas, 2019). Al adherirse a estas reglas, se generaba una película mas verosímil y conectaba mejor con las audiencias, si se pausara cualquier cuadro de la película, se puede ver como todo lo que aparece puede ser construido con piezas que se encuentran en la vida real. El filme fue bastante revolucionario en técnicas de animación pues hubo 15.080, 330 piezas que fueron animadas y 182 mini figuras (Simbaña, 2018). Los primeros bocetos de las estructuras y vehículos fueron diseñados en un software llamado Lego Digital Designer y después, en un programa de animación llamado Maya, a cada bloque se le añadieron características únicas que los hacían más reales como marcas de dedos, marcas de desgaste por el uso, polvo, etc.

\subsubsection{Lego y el Stop-motion}

Este vínculo se remonta hasta 1973, en donde dos niños daneses de 10 y 12 años filmaron un corto llamado Viaje a la Luna, el cual fue realizado para conmemorar las bodas de oro de sus abuelos (Drobnitzky, 2017) y actualmente es reconocido popularmente la primera vez que alguien hizo un filme de Lego utilizando esta técnica. Este tipo de películas fueron conocidas como Brickfilms. Con los años, esto se fue popularizando y los entusiastas, al hacer estas películas, utilizaban la técnica tradicional del stop-motion, en donde el metraje era grabado en series de dos, lo que significaba que se tomaban 12 fotografías, ajustando y cambiando se posición a los personajes en cada una de ellas para así juntarlas y lograr un segundo de película, por otro lado, para escenas que requerían una sensación de movimiento más notoria, se tomaban 24 fotografías. Si bien La Película Lego no utilizó la técnica tradicional, logra darle ese efecto 
mediante un proceso de animación especial, asimismo, este filme también es una especie de homenaje para todos aquellos que son amantes de esta marca, haciéndoles saber a todos sus usuarios que no existen límites cuando se trata de imaginar y crear.

\subsubsection{Lego Education}

Desde hace algunos años LEGO, la compañía de ladrillos para armar se convirtió en algo más que solo un juego para mantener ocupados a los niños, hoy es una herramienta que permite educar, ejercitar la creatividad y sobre todo poder solucionar problemas. Dentro de las divisiones creadas en los últimos tiempos en la compañía existe una llamada LEGO EDUCATION que según el portal Robotix de España (empresa dedicada a distribuir la metodología y materiales) más que aprender y educar a través de la robótica se puede educar en diversos temas simplemente siendo creativos al momento de utilizarlos, teniendo muy claro que se busca y sobre todo la finalidad del motivo educacional. Robotix 1 afirma que el primer producto de robótica LEGO Technic fue pensado para las aulas, porque su creador Seymour Papert era un gran educador. Es por eso que introdujo muchas ideas nuevas a la educación, como creer en la tecnología educativa como base para construir grandes cosas, aprender a través de la motivación, el interés intrínseco durante el aprendizaje del alumnado y sobre todo la diversión durante el proceso.

Metodología 4C de LEGO Education: aprendizaje continuo en las aulas desde los inicios de formación en la escuela hasta nuestras carreras profesionales, la formación continua es esencial para la adquisición de nuevos conocimientos y el mantenimiento de estos. Para ello, es importante contar con una metodología de trabajo que permita priorizar nuestros proyectos y trabajar hacia la consecución de los objetivos planteados.

1 Robotix, empresa española dedicada a la eneseñanza de robótica a través de las piezas para armar de LEGO, https://www.robotix.es/blog/historia-lego-education/ recuperado el 20 de noviembre del 2019 
Para ROBOTIX, la metodología LEGO Education está basada en la construcción activa y el descubrimiento guiado por parte de un facilitador que permita guiar al alumno en el descubrimiento de su propio conocimiento. Este a su vez tiene un orden y no es simplemente jugar por jugar, sino que le metodología de LEGO Education está justamente centrada en la búsqueda de soluciones que pueden ser sencillas o complejas pero que al ser abordadas con esta metodología su desarrollo se hace más ágil y amigable. Pero lo más importante es que se convierte en algo divertido, ameno, ágil captando la atención y participación de los involucrados.

El uso de la metodología permite el desarrollo de habilidades y competencias. El principal cambio en los últimos años en la sociedad ha sido el paso de la sociedad industrial a la sociedad creativa, donde la tecnología ha visto su papel renovado en una vía más de aprendizaje y no como un acelerador de la reproducción del conocimiento. La tecnología, en este sentido, ha visto reconvertida su utilidad en mezclar y fusionar diferentes medios para la creación de nuevas e innovadoras expresiones y para el fomento de las habilidades y competencias del siglo XXI (como el trabajo en equipo, la comunicación y la creatividad), que en la metodología LEGO se expresa por sí solo.

Para nosotros, el verdadero aprendizaje ocurre cuando las personas tienen la oportunidad de explorar el mundo por sí mismas, pero en un entorno guiado. Cuando crean cosas en el mundo físico, construyen conocimiento en sus mentes de forma mucho más fácil y consistente.

\subsection{Metodología}

El enfoque empleado por la empresa Robotix, socia de LEGO en el rubro educativo se basa en un marco de 4 "C" donde los estudiantes son libres de experimentar y explorar a medida que obtienen nuevos conocimientos. Se anima a colaborar mientras trabajan a través de tareas 
abiertas e ideas de extensión, facilitadas y guiadas en todo momento por el profesorado. Las bases de esta metodología son:

- Conectar: se expone el tema o proyecto, de forma que desde ese momento se le permite al alumno hacer preguntas clarificadoras y desarrollar los conocimientos que se tenían hasta entonces. Se contextualiza poniendo como base una situación cotidiana que se haya vivido.

- Construir: cada tarea incluye una actividad de construcción para promover la experimentación y explorar. En ese momento se construye un modelo o proyecto gracias al apoyo de las guías que proporciona LEGO Education.

- Contemplar: observar a los estudiantes reflexionar sobre lo que se ha aprendido y compartir ideas y puntos de vista. Es el momento para crear debate entre los alumnos y profesores, respondiendo preguntas como: ¿qué se observa?, ¿por qué funciona así?, ¿a qué se debe esta situación?, etc.

- Continuar: cada tarea terminada con una nueva tarea conectando con lo que se acaba de aprender, manteniendo la motivación e interés. Es el momento en que se resuelve el reto, incentivando a proponer otro para fomentar su creatividad, encontrando diferentes alternativas de solución para un mismo problema.

Como hemos podido analizar, el uso de LEGO en la educación de todo nivel es una práctica que se ha venido utilizando hace muchos años y que hoy en día se extiende a través de las diversas clases sociales y culturas que pueden encontrar en este método una metodología capaz de hacer concentrar a nuestros alumnos y ser más creativos e innovadores.

Es por ello que hablar de educar a través de LEGO no resulta descabellado sino más bien adecuado y pertinente. En el proyecto que se propondrá más adelante está relacionado con cómo utilizando los ladrillos de LEGO podemos captar la atención y enviar un mensaje claro y puntual 
a diversos jóvenes mediante un video educativo y así poder abordar temas como la educación y violencia vial que buscará despertar conciencias y ser capaces de entender este problema.

\subsection{Estado del arte}

A. "Aula en bici: un proyecto longitudinal de intervención docente en Ed. Primaria." Otín, C. C., de la Fuente, F. P., López, M. R., Risco, I. C., \& Gómez, S. P. (2013).

El desarrollo y la aplicación didáctica de un proyecto educativo que articule un contenido asociado a la utilización de la bicicleta, como recurso con amplias posibilidades educativas, es el objetivo del presente trabajo. El proyecto docente realizado se denomina el Aula en bici. Se trata de una experiencia didáctica piloto, en la que se efectúa un tratamiento pedagógico de carácter longitudinal, al vertebrar los objetivos y contenidos de trabajo a lo largo del segundo y tercer ciclo de Educación Primaria (de $3^{\circ}$ a $6^{\circ}$ curso). La vinculación con los bloques de contenido del Área de Educación Física establecidos por el Gobierno de Aragón (DGA) sitúa esta experiencia en el bloque de las habilidades motrices y en el de actividad física, salud y educación en valores. Esta experiencia ha logrado aproximar el contenido de la bicicleta desde una triple perspectiva: como medio de transporte urbano, como modalidad deportiva ecológica y saludable, y como herramienta para descubrir el medio natural.

B. "El Lego Serious Play como herramienta para solucionar problemas sociales. Estudio con alumnos de administración de empresas.” - Villamizar Acevedo, G., \& González Ambrosio, J. E. (2015).

Resolver problemas es una de las actividades centrales de ser humano y se manifiesta en tareas tanto laborales como lúdicas. Con el objetivo de conocer la eficacia del Lego Serious Play (LSP), herramienta que consta de una serie de piezas, que deben ser ensambladas hasta crear un modelo inicialmente concebido en la mente. Se realizó una investigación experimental, para ello 
se trabajó con 14 estudiantes de primer semestre de la Facultad de Administración de Empresas de la Universidad Pontificia Bolivariana Bucaramanga (UPB), de la primera cohorte del 2013, nueve hombres y cinco mujeres, con una edad promedio de 18.2 años, con una desviación de 1.26. Este grupo se dividió en dos subgrupos, experimental y control. El experimental con seis estudiantes (cuatro hombres, dos mujeres, edad promedio 18.2 años) y el control con ocho (cinco hombres, tres mujeres, edad promedio 18.3 años). Con el grupo experimental se trabajó con el LSP y con el otro con lápiz y papel. El análisis de los resultados permitió dar cuenta que el trabajo con el LSP generó mayor cantidad de situaciones problemáticas así como soluciones a los mismos que los del modelo de lápiz y papel. Los resultados obtenidos dejan ver la utilidad de esta herramienta en el ámbito escolar para el desarrollo de habilidades cognitivas que permite solucionar problemas. 


\section{CAPÍtulo II}

\subsection{Análisis del público objetivo}

El público objetivo seleccionado para este proyecto está conformado por jóvenes en edades de 18 a 22 años de la ciudad de Lima, Perú, debido a que están en una edad que acaban de obtener o están próximos a tramitar sus licencias de conducir. Pertenecientes al sector B y C pues tienden a conducir un vehículo particular (familiar) y suelen estudiar en universidades o institutos y algunos de ellos se inician en el mundo laboral, lo que significa que las probabilidades de que conduzcan en horas picos son altas y por ende, estarían enfrentándose al caos vehicular limeño constantemente. El público objetivo conoce el reglamento de tránsito porque lo estudiaron para dar el examen teórico o lo van a dar-; sin embargo, resulta increíble que habiendo aprobado su examen no ponen en práctica nada de lo estudiado. Uno de los factores principales por lo que se apunta a jóvenes es que podemos despertar conciencia en ellos haciéndoles ver los problemas tan graves que se generan por el hecho por ejemplo de parar en un lugar que no es apto para ello. De esta manera, lo que busca el proyecto es contribuir a disminuir significativamente el caos vehicular para así evitar estrés y con ello no activar la violencia vial.

De la misma manera, enfocarse en este público permitirá que se genere una nueva generación de conductores que estén mejor informados, educados y capacitados, pues para que no se sigan replicando las mismas infracciones y conductas que contribuyen al caos vehicular es necesario inculcar el sentido de comunidad y beneficio colectivo en los jóvenes, haciéndoles entender que de ellos depende el cambio en la sociedad y la importancia de conocer y respetar las reglas de tránsito. 


\subsection{Descripción del proyecto de diseño}

El proyecto consiste en realizar una campaña de concientización a través de un video educativo enfocado a jóvenes que estén en edades próximas a obtener una licencia para conducir, y en aquellos que ya tienen una que estén entre los 18 y 22 años de edad. Serán instruidos en temas como las leyes de tránsito y seguridad vial. Se diseñará un video interactivo utilizando como recurso principal el "stop-motion", la cual es una técnica que consiste en colocar un gran numero de fotografías en secuencia, generando así la ilusión de movimiento. Este video mostrará diversos casos de infracciones que suelen ocurrir a diario, y que las personas no son conscientes que estas pequeñas faltas ocasionan grandes congestiones; como, por ejemplo, pararse en medio de una intersección obstaculizando el desplazamiento de muchos otros vehículos. En el video en determinado momento se pausará y se les mostrará dos posibles soluciones a los jóvenes, preguntándoles que harían ellos frente a dichos casos, luego se mostrará la opción elegida mediante otro video que recreará las consecuencias de dicha opción sea positiva o negativa. Con ello se pretende lograr crear conciencia sobre la importancia de respetar el reglamento de tránsito, y que no importa si son unas pocas personas quienes si lo respetan si no que estas pocas acciones si contribuyen a tener ciudadanos más responsables que respetan las normas de una ciudad civilizada y que si es posible mejorar y cambiar las cosas, pero sobre todo ser un grano de arena para que otros nos imiten.

Por otro lado, se contará tanto con registro fotográfico y audiovisual como con encuestas de entrada y salida, para poder medir la eficacia de los métodos implementados y de su pregnancia en los usuarios. 


\subsection{Proceso del diseño}

\subsubsection{Concepto del proyecto}

El proyecto tiene el RESPETO al OTRO mediante un CONOCIMIENTO de las leyes y reglamentos como concepto principal, debido a que el problema del caos vehicular ocasiona que las personas adopten una actitud agresiva y egoísta al solo pensar en ellos mismos. Si analizamos quién es el otro resulta que somos nosotros mismos. Por ello el concepto dirigido a jóvenes entre los 18 y 22 años también requiere de una gran cuota de EMPATÍA y AMABILIDAD con esto permitirá llegar de manera clara, efectiva y afectiva. Los jóvenes de hoy, que es el público objetivo, no funcionan con la imposición de ideas a la fuerza o de manera rígida y dictatorial, sino con un planteamiento creativo y amigable.

Al momento de conducir si solo pensáramos por un momento en los demás, se entendería que muchas de las congestiones que se generan serán de menos tiempo y más fluidas; sin embargo, otro aspecto importante a tener en cuenta es que el caos es ocasionado porque no se conoce bien el reglamento de tránsito, es por ello que el concepto adopta los puntos mencionados anteriormente para generar una actitud de desprendimiento personal, sentido de comunidad y beneficio mutuo basados en el apropiado conocimiento de las leyes y reglas de tránsito.

Por todo lo expuesto se considera que el concepto es el más apropiado para este público objetivo, pues en los jóvenes recae la responsabilidad de impedir que las conductas que contribuyen al caos vehicular y la agresión se sigan replicando, de esta manera se les hace entender lo importante que es conocer bien las leyes y pensar no solamente en el beneficio propio, haciendo énfasis en que ellos son un componente importante en la solución de esta problemática que día a día sigue aumentando. 


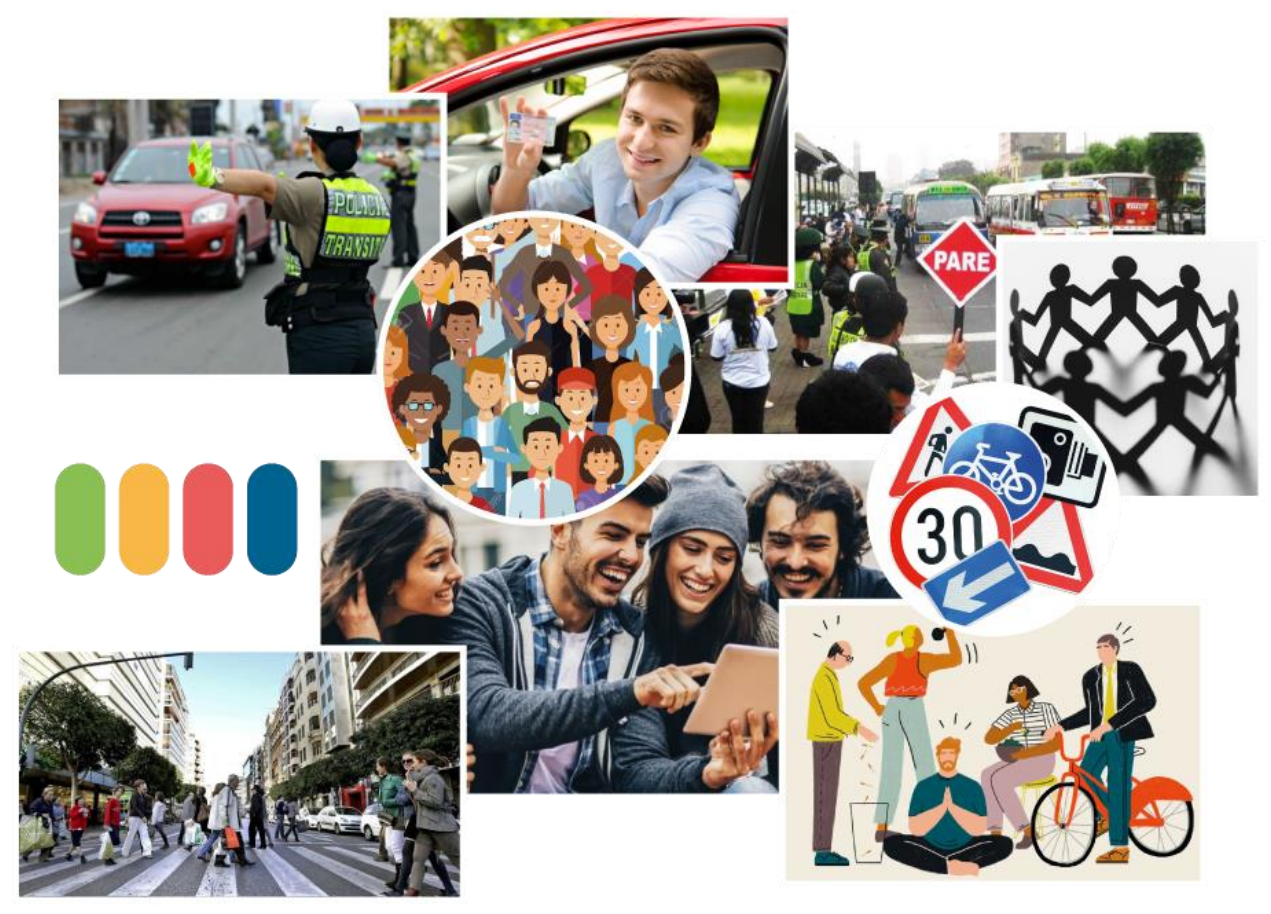

Figura 3.1. Moodboard conceptual del proyecto. Fuente: Propia.

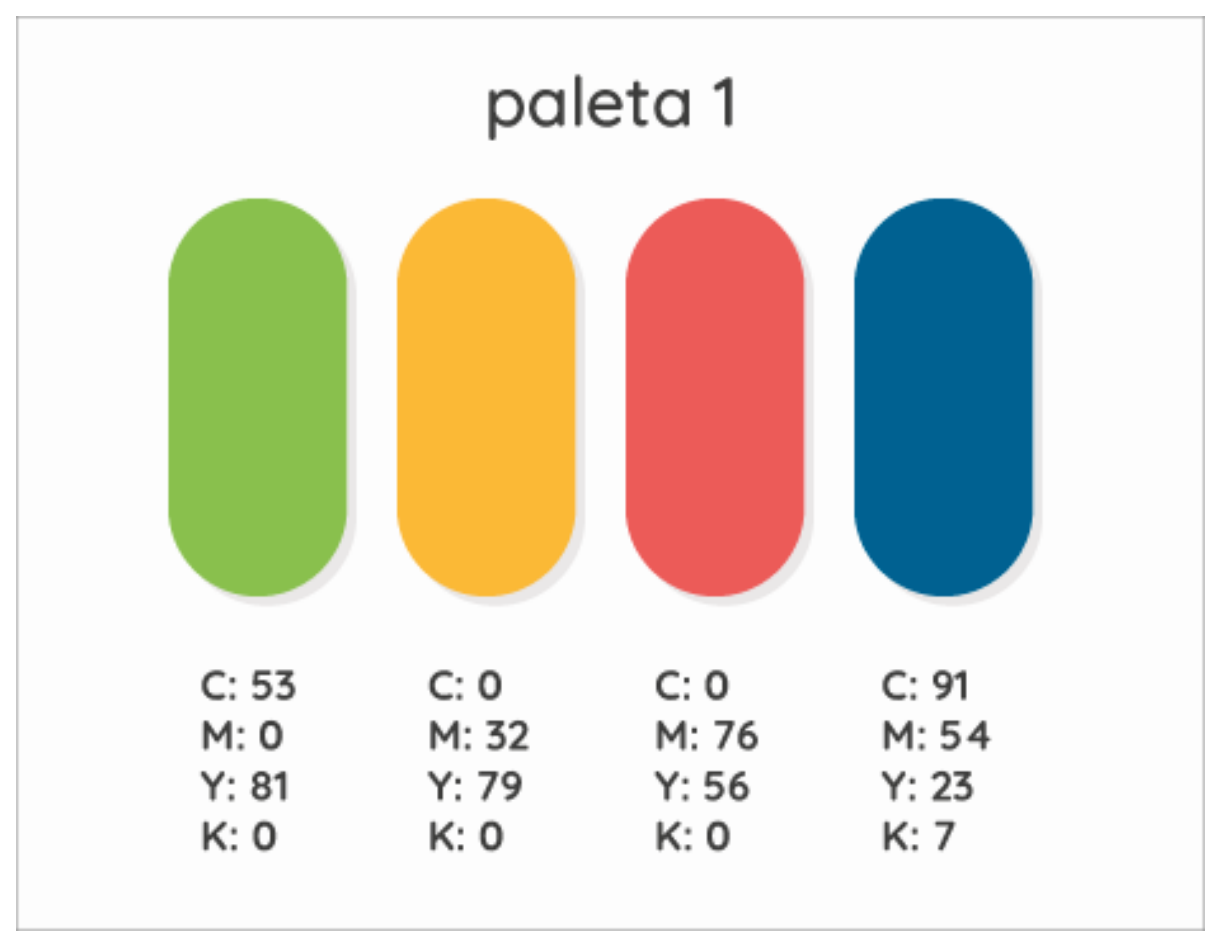

Figura 3.2. Propuesta uno de paleta de color para el proyecto. Fuente: Propia. 


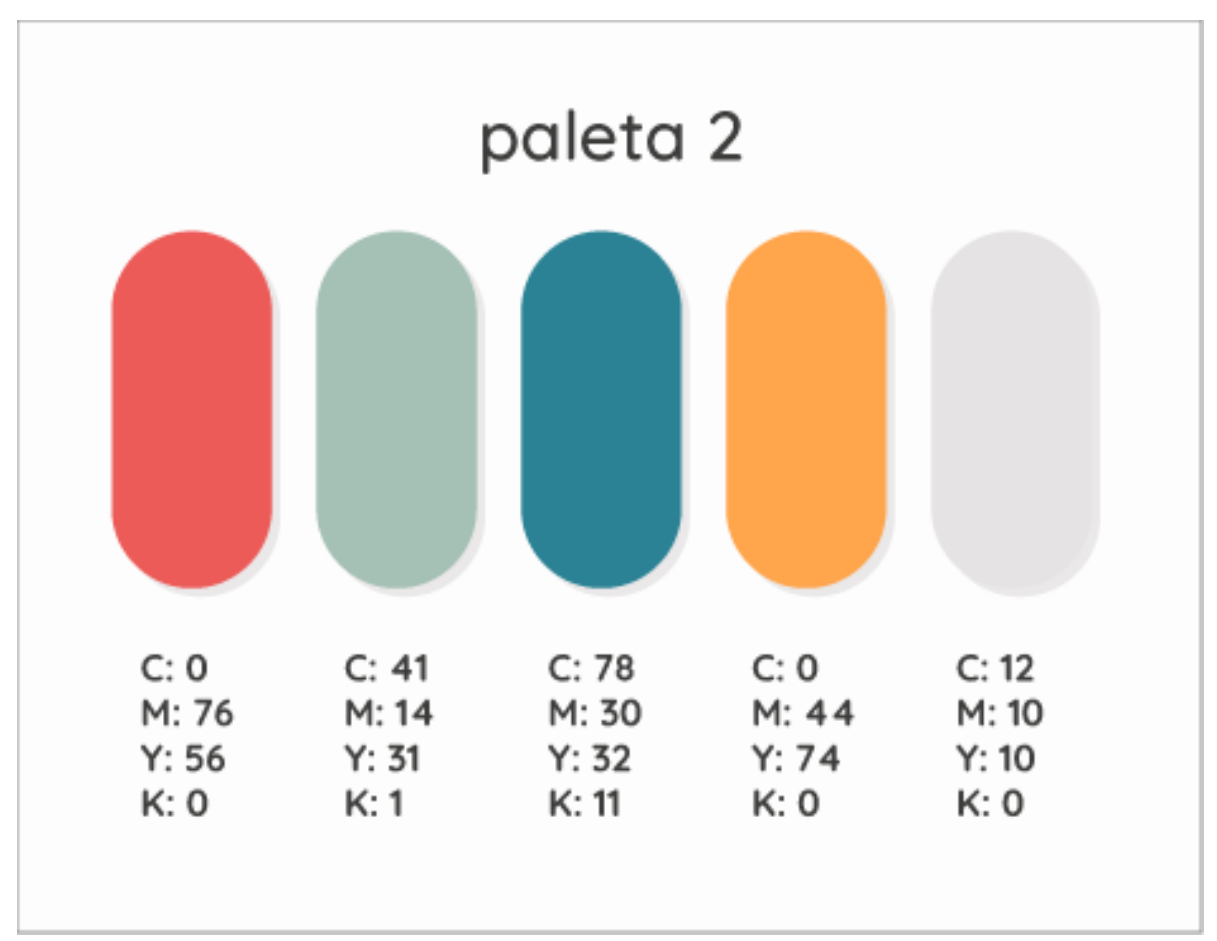

Figura 3.3. Propuesta dos de paleta de color para el proyecto. Fuente: Propia.

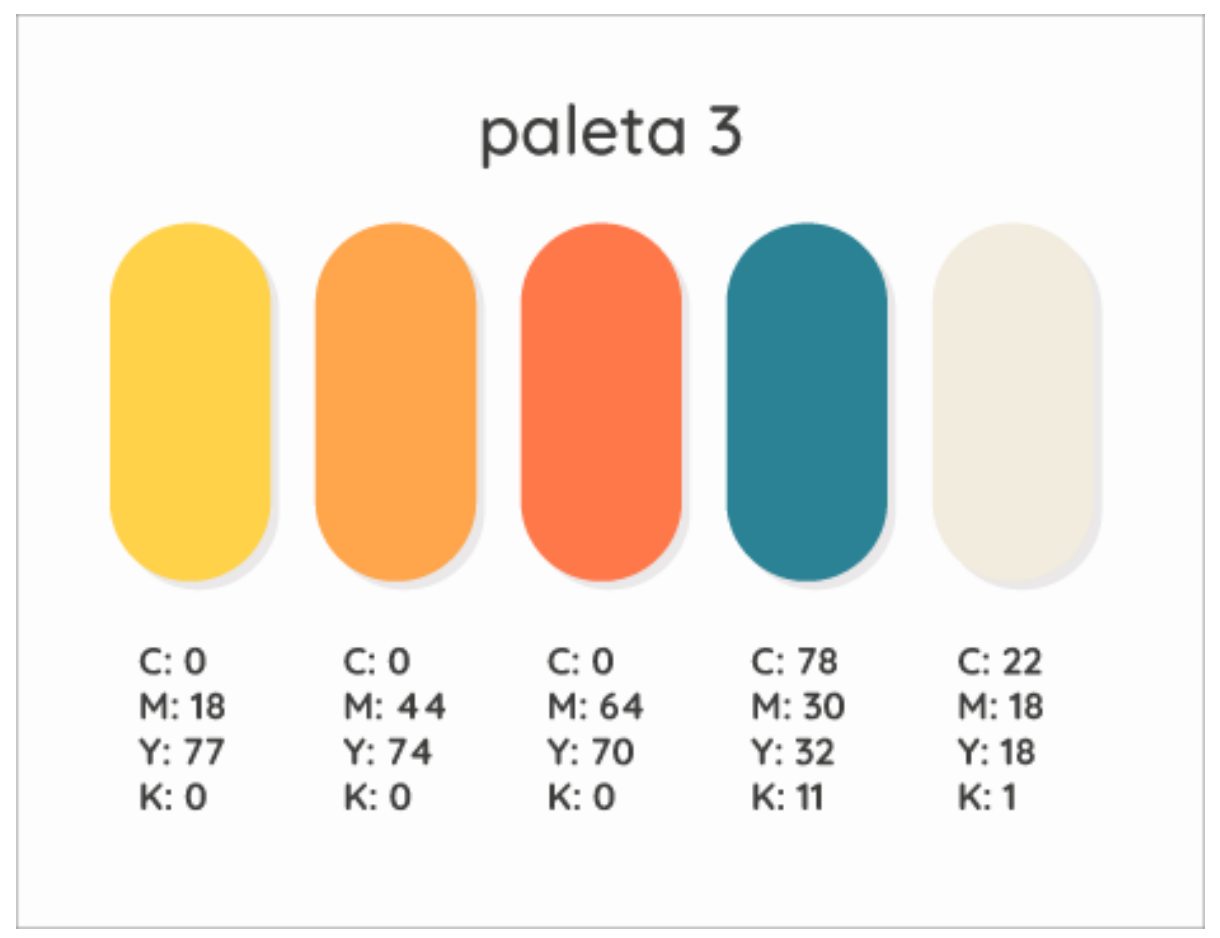

Figura 3.4. Propuesta tres de paleta de color para el proyecto. Fuente: Propia. 


\section{Quicksand}

\section{Aa Bb Cc Dd Ee Ff Gg Hh li Jj Kk LI Mm Nn Ñ̃̃ Oo Pp Qq Rr Ss Tt Uu Vv Ww Xx Yy Zz 0123456789}

paleta tipográfica 1

Figura 3.5. Propuesta uno de paleta tipográfica para el proyecto. Fuente: Propia.

\section{Kollectif}

$\mathrm{Aa} \mathrm{Bb} \mathrm{Cc} \mathrm{Dd} \mathrm{Ee} \mathrm{Ff} \mathrm{Gg} \mathrm{Hh} \mathrm{Ii}$ Jj Kk LI Mm Nn Ññ Oo Pp Qq Rr Ss Tt Uu Vv Ww Xx Yy Zz 0123456789

paleta tipográfica 2

Figura 3.6. Propuesta dos de paleta tipográfica para el proyecto. Fuente: Propia. 


\section{Recoleta}

\section{$\mathrm{Aa} \mathrm{Bb} \mathrm{CcDd} \mathrm{Ee} \mathrm{Ff} \mathrm{Gg} \mathrm{Hh} \mathrm{li}$ Jj Kk Ll Mm Nn Ññ Oo Pp Qq Rr Ss Tt Uu Vv Ww Xx Yy Zz 0123456789 paleta tipográfica 3}

Figura 3.7. Propuesta tres de paleta tipográfica para el proyecto. Fuente: Propia.

\subsubsection{Nombre del proyecto}

El nombre del proyecto es "Educar: Conduciendo sin violencia" el cual es un juego de palabras que engloban el concepto del proyecto -RESPETO al OTRO, CONOCIMIENTO, EMPATÍA Y AMABILIDAD- así tenemos “Edu” que evoca educación y "car” que en inglés significa carro y que en castellano mismo connota vehículo. De esta manera se enfatiza visualmente para facilitar su comprensión al lector. Por ello se utiliza una tipografía que identifica esa amabilidad y respeto con rasgos simples. La paleta de colores utilizada en el proyecto consiste en tonos utilizados que connotan principalmente tránsito sin serlo explícitamente. Finalmente tenemos una marca fresa simple, fácil de llegar a nuestro público objetivo sin complicaciones y así poder lograr los objetivos de comunicación del proyecto. 


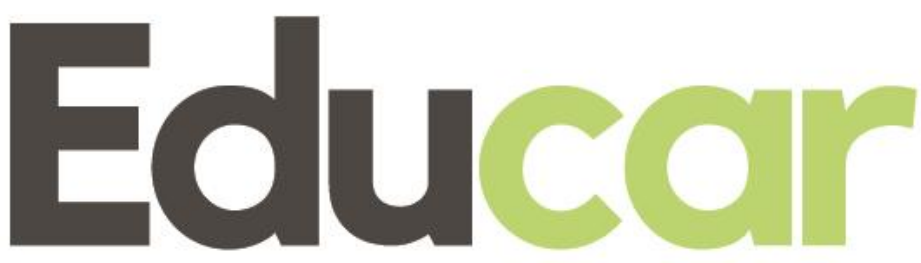

C O N D U C I E N D O S I N V I O L E N C I A

Figura 3.8. Logo final del proyecto.

Fuente: Propia

\subsubsection{Fundamentación del proyecto}

Educar es un programa de prevención de violencia vial que enseña la importancia de cumplir con el reglamento de tránsito que permite una disminución significativa de la congestión, hace más llevadero el paso y circulación, por lo tanto, hay una disminución significativa de la violencia vial como insultos, peleas, acciones temerarias, etc. El caos vehicular en Lima ha alcanzando niveles alarmantes, lo que genera molestia e incomodidad en toda la población, la falta de conocimiento del reglamento de tránsito y la actitud agresiva que se genera en los conductores no contribuyen a que este problema tenga solución. Es por ello que este proyecto apunta a las nuevas generaciones de conductores, haciéndoles saber que es importante respetar las leyes y dejar de pensar en el beneficio propio a la hora de conducir, pues las acciones que tomamos afectan al resto de conductores y es necesario mejorar. Asimismo, para este proyecto se espera que, al escuchar el mensaje, los jóvenes tomen conciencia, que comprendan la importancia de respetar las reglas de tránsito para que no sigan cometiendo los 
mismos errores que las generaciones anteriores y sobre todo fomentar el sentido de comunidad y respeto hacia el otro. Diseñar un video con el fin que permita un adecuado conocimiento del reglamento de tránsito y de su correcta aplicación resulta importante porque con ello demostramos que mediante el diseño y sus herramientas podemos generar cambios en la sociedad que permitan una sana convivencia en paz y tolerancia. El diseño de un video no sólo es educar por educar es hacerlo de manera tal que los conocimientos a transmitir permitirán que estos queden en las personas como algo permanente y que lo puedan hacer parte de su día a día.

\subsection{Diseño de la comunicación}

El público objetivo está compuesto principalmente de jóvenes entre los 18 y 22 años que estén estudiando en universidades o institutos, debido a que es a esa edad cuando empiezan a informarse acerca del proceso de trámite de una licencia para conducir; y que luego otros después de haberlo obtenido hacen caso omiso de todo lo que leyeron o aprendieron para el examen. Al apuntar a este sector, se poseen diversas ventajas, entre ellas está la disposición que los jóvenes tienen para aprender, también el querer ser parte de un cambio, puesto que ellos han crecido viviendo día a día el caos vehicular de la ciudad y saben lo frustrante que es esta problemática y por último, al tener una población joven bien educada y con el conocimiento adecuado podemos esperar a que se un efecto que se multiplique en las generaciones que vengan luego, puesto que se evita replicar las mismas malas conductas que conllevan a este caos.

Por otro lado, teniendo en cuenta el concepto del proyecto referido al RESPETO al OTRO mediante un CONOCIMIENTO de las leyes y reglamento que incluye una actitud EMPÁTICA y AMABLE se elige como instrumento de apoyo para la realización de este video las piezas de construcción de LEGO, puesto que es un referente educativo, lúdico y que mediante 
estas piezas actualmente se desarrollan muchos programas para desarrollar la búsqueda de soluciones creativas a diversos problemas. Esta herramienta no solo es un juego, es como dijimos un instrumento educativo que con la orientación adecuada y junto con un buen diseño puede lograr transmitir conocimientos útiles y beneficiosos a los actores involucrados. Para hacer que el mensaje sea recibido de manera correcta es necesario también hacer énfasis en la importancia que tiene el papel que nuestro público objetivo posee, pues conforman las futuras generaciones de conductores y de ellos depende contribuir en este cambio de actitud y conducta que se busca, por ello es importante que el proyecto sea difundido a la mayor cantidad de personas mediante plataformas y canales virtuales, como redes sociales y portal web. Este proyecto cuenta con tres fases, la primera es de intriga en donde se darán a conocer ideas generales sobre el mismo para despertar el interés del público objetivo, lo que dará paso a la segunda etapa, la implementación, en donde se realizará la dinámica del video interactivo con los jóvenes y un posterior acercamiento a un sitio web en donde se encontrará más información relacionada al tema y cómo ser un buen conductor que contribuye a tener un tráfico más fluido.

\subsubsection{Receptor}

El público objetivo es principalmente joven, entre los 18 y 22 años de edad, que se encuentre a punto de empezar a tramitar sus licencias de conducir o que no ha pasado mucho tiempo de haberla obtenido. Pertenecen al sector socioeconómico B y C, por ende, tienden a conducir un vehículo particular. Este público suele estudiar en universidades e institutos y por esta razón, una vez que tengan sus brevetes, empezarán a conducir a sus centros de estudio sea de manera diaria o interdiaria. Respecto al estado civil, la gran mayoría son solteros, pero pueden tener pareja, lo que significa que pueden conducir los fines de semana a diversos lugares de recreación. No suelen tener muchos gastos pues gran parte de este sector sigue viviendo con sus 
padres, sin embargo, tampoco suelen contar con ingresos fijos por estar en las primeras etapas de sus estudios superiores.

\subsubsection{Emisor}

El emisor es el mismo proyecto que envía el mensaje de lo importante y necesario que es respetar las reglas básicas de tránsito. Con ello se busca informar acerca de cómo podemos generar un tráfico menos estresante o congestionado a partir del cumplimiento de un reglamento esencial que permite una convivencia sana y próspera. El proyecto es importante porque concientizará a la futura generación de conductores acerca de los beneficios de conocer y respetar las reglas de tránsito, pues de esta manera, se generará un cambio de actitud y de comportamiento que repercutirá de manera positiva en la sociedad.

\subsubsection{Canales y medios}

Los principales canales y medios serán digitales, puesto que se puede tener mayor alcance mediante ellos y son considerados los más indicados y eficientes para poder llegar al público objetivo. Definitivamente las redes sociales tendrán un gran protagonismo, se elegirá adecuadamente cuales serán usadas y en que momentos dependiendo de las características del público objetivo. La campaña al contar con tres etapas, usará estos medios para poder generar interés, informar, concientizar, cuantificar y medir el rango de alcance y efectividad que tuvo en los usuarios, lo que permitirá tener un constante control y monitoreo de la campaña.

\subsubsection{Mensaje}

El concepto elegido RESPECTO al OTRO mediante un CONOCIMIENTO de las leyes y reglamento que incluye una actitud EMPÁTICA y AMABLE permite enviar el mensaje de IMPORTANCIA de conocer y aplicar correctamente el reglamento de tránsito y cómo ello contribuye de manera significativa a poder tener un tráfico más fluido y menos congestionado y 
la importancia del papel que tienen los jóvenes como futuros y actuales conductores, pues de ellos depende evitar que se sigan repitiendo infracciones, conductas de riesgo y la agresividad que se observa en la actualidad. De la misma manera, es necesario fomentar los beneficios de ser un conductor responsable y sobre todo un conductor que piensa de manera colectiva y no busca el beneficio propio. Inculcar una cultura de respeto al otro permitirá que se genere progreso a largo plazo.

\subsection{Estudio de la comunicación}

\subsubsection{Sintaxis}

El mensaje está basado en un aprendizaje constructivista, fomentando la creación de una cultura de civismo y respeto a la comunidad, en donde el beneficio propio no se interponga en el bienestar colectivo. Está constituido por dos partes, en la primera se le pregunta al usuario acerca de sus conocimientos frente a temas de reglamentación vial y situaciones cotidianas que enfrenta a diario, en base a esto, se procede luego a concientizarlo y brindarle conocimientos sobre las reglas de tránsito y posteriormente generar esa actitud de cambio en ellos.

\subsubsection{Simbología}

Con la gráfica elegida y el hecho de utilizar piezas LEGO en el elemento central para el proyecto, se desea transmitir la empatía, orden, simplicidad, progreso, optimismo y comunidad. Normalmente el tráfico limeño se asocia con ideas negativas, estrés, caos, desorden, multitudes, etc. que efectivamente ocurren, pero que queremos contribuir a revertir. Por ello este proyecto aborda el tema desde un ángulo diferente, en donde se muestra mediante el recurso de piezas de construcción LEGO que una de las mejores maneras de aprender es con diversión, de esta 
manera el usuario sentirá que él puede ser parte de la construcción de un nuevo futuro y de una nueva generación de conductores más responsables y conscientes.

\subsubsection{Pragmatismo}

La información brindada será extraída del reglamento de tránsito, pero será intervenida gráficamente para que pueda ser asimilada de una manera más didáctica por parte del público objetivo, asimismo, la estética utilizada y las piezas gráficas a trabajar han sido elegidas debido a que resultan visualmente atractivas y fáciles de comprender y utilizar.

\subsubsection{Estética}

El estilo gráfico utilizado está basado en un estilo simple, dinámico, básico y lúdico. Simple, porque partimos de ladrillos de construcción LEGO que utilizan formas primarias como cuadrado y círculo, por ello le daremos un grado de dificultad a mayores con figuras o elementos complicados. Básico, por el mismo principio de formas elementales y al mismo tiempo referido a la simpleza de colores utilizando para ellos los colores primarios rojo, amarillo y azul; lo mismo con las tipografías utilizadas que serán simples, sencillas, de palo seco como Arial, Helvética o Futura. Lúdico, al recurrir al diseño de un video interactivo de stop-motion, con piezas LEGO para lograr generar una aceptación y participación por parte del público objetivo.

\subsection{Implementación}

La implementación de este proyecto constará de tres etapas. La primera es una etapa de intriga, la segunda es la etapa de implementación, en donde se realizará la dinámica del video interactivo y la charla con un experto y por último está la fase de difusión, en donde se usarán 
plataformas digitales para poder tener un mayor rango de alcance. Para poder medir los resultados se usarán encuestas de entrada y salida, lo que determinará si la dinámica fue la más apropiada y si los jóvenes consideraron los métodos utilizados como los más apropiados, de la misma manera, las plataformas digitales permitirán obtener resultados a mayor escala y poder cuantificar el nivel de eficacia de la campaña. 


\section{Conclusiones}

Esta investigación permite concluir que la violencia urbana es un fenómeno que se deriva muchas veces del no respetar las disposiciones más básicas del reglamento de tránsito, al no ser cumplidas, desencadenan una serie de hechos muy peligros que pueden conllevar a la muerte de personas inocentes. Un grito furioso, acelerar el carro para insultar, hacer una acción temeraria a otro carro pueden terminar en tragedias que marcaran por siempre la vida de los involucrados y de aquellos que no tienen nada que ver con la situación. Es por ello que se hace necesario abordar el problema desde la raíz. Cuando obtenemos un permiso de conducir hemos pasado por un examen que se supone garantiza saber las leyes de tránsito, pero en la realidad sabemos que no es así. Es así que diseñar un plan de enseñanza de las principales normas del reglamento de tránsito y de las infracciones que suceden con mayor frecuencia en el tráfico de Lima es un medio adecuado para lograr hacer reflexionar sobre la violencia vial.

Si nuestro público objetivo son jóvenes llegar a ellos de manera lúdica se hace indispensable, por esa razón que realizar un video utilizando piezas de LEGO que son universalmente conocidas se hace más amigable el poder entender el mensaje que se desea transmitir, con lo cual se concluye que conceptos importantes pueden ser fácilmente transmitidos mediante el uso de videos lúdicos.

El proyecto permite que los jóvenes que manejan vehículos particulares tomen conciencia de la importancia de respetar el reglamento de tránsito y manejar de manera prudente sin dejarse llevar por los impulsos y la ira desatando de esa manera la violencia vial, evitando problemas mucho más severos. 
La técnica del stop motion en un video resulta muy adecuado ya que logra captar la atención del receptor y conectar con el público objetivo de una manera natural y efectiva debido permitiendo que el mensaje sea recordado y que sobre todo sea comprendido, primero porque es elaborado teniendo en cuneta como los jóvenes reciben los mensajes hoy en día con la característica de ser breve en duración puntual en el mensaje y directo en la recordación.

El proyecto pretende mostrar que a pesar de que haya muchas personas que manejen con imprudencia, bastará que unos pocos empiecen a generar este cambio de conducta para que, con el tiempo, estas acciones empiecen a tener resultados y así cada vez más gente imite este comportamiento, reduciendo la violencia vial y el número de accidentes. 


\section{Recomendaciones}

Es recomendable que usando esta misma técnica se pueda utilizar no solo para educar y concientizar a jóvenes sino también a niños en situaciones de educación vial, de esta manera estaremos formando futuros ciudadanos responsables en materia vial.

Es importante poder difundir el proyecto vía las principales plataformas digitales como Instagram, Facebook y YouTube, puesto que en estas redes es donde se encuentra gran parte del público objetivo elegido.

Generar conciencia sobre la importancia de conocer y respetar las leyes de tránsito, y también hacer énfasis en lo crucial que es la empatía al conducir para así reducir el caos vehicular y la agresión vial es importante y necesario, por ello es recomendable poder realziar campañas similares con otros elementos para un sector más maduro.

Es recomendable que otros tipos de problemas como drogas puedan ser enfocardos en los jóvenes de una manera lúdica y directa para poder tener una nueva generación responsable y consciente de sus problemas. 


\section{Referentes bibliográficos}

Alfaro, L., \& Saavedra, K. (2008). Los servicios públicos en el Perú: una visión preliminar. Serie Doctrina, 589-600.

Ambert-Cabrera, Y. (2016). Violencia urbana en Puerto Rico y las experiencias de la víctima (Order No. 10014804). Available from ProQuest Central. (1767229978). Retrieved from https://search.proquest.com/docview/1767229978?accountid=43847

Arce, A. E. V. (2016). De la interfaz del usuario al responsive web design. Revista AUC, (37), 59-66.

Arenas, A., \& Marino, K. J. (2016). Diseño de un sistema de clasificación de señales de tránsito vehicular utilizando redes neuronales convolucionales.

Bambarén, C., \& Chú, M. (2013). Regulación del transporte y accidentes de tránsito por vehículos motorizados en el Perú. Revista Medica Herediana, 24(4), 305-310.

Bastidas, A., \& Martínez, H. R. (2016). Diseño social: Tendencias, enfoques y campos de acción. Arquetipo, (13), 89-113.

Bodelón, E. (2015, January). Violencia institucional y violencia de género. In Anales de la Cátedra Francisco Suárez (Vol. 48, pp. 131-155).

Boesten, J. (2008). Narrativas de sexo, violencia y disponibilidad: raza, género y jerarquías de la violación en Perú. Raza, etnicidad y sexualidades, 199-220.

Briceño-León, R. (2002). La nueva violencia urbana de América Latina. Sociologías, 4(8), 3451.

Cannone, M. Á. (2016). Historia del Cine Universal. 
Carrasco, J. C. (2007). Violencia doméstica: lo que revela la investigación básica con parejas. Papeles del psicólogo, 28(1), 57-62.

Choquehuanca-Vilca, V., Cárdenas-García, F., Collazos-Carhuay, J., \& Mendoza-Valladolid, W. (2010). Perfil epidemiológico de los accidentes de tránsito en el Perú, 2005-2009. Revista Peruana de Medicina Experimental y Salud Pública, 27, 162-169.

Cisneros, J. (2011, noviembre-diciembre). A propósito de la violencia: una mirada del sociólogo a nuestra violenta cultura. El Cotidiano, 57-66.

Congestión vehicular en Lima y Callao genera pérdidas por más de S/5.000 mlls. al año. (2019, 3 enero). Recuperado 13 agosto, 2019, de https://elcomercio.pe/economia/peru/costo-anualtrafico-lima-callao-s-5-541-5-millones-noticia-593591

Cortés, C. M. P. (2017). Educación vial en la era digital: cultura vial y educación permanente. Diálogos sobre educación, (15).

Drobnitzky Hill, L. (2017). Explorando la técnica del stop-motion.

El Comercio. ¿A qué se atribuye la congestión vehicular? 26 de Julio de 2014a. Disponible en: (último acceso: 15 de Diciembre de 2016).

Farfán, M. (2016). Las posibilidades creativas e interdisciplinarias del diseño aplicado a la animación stop-motion. Memoria Gráfica, (9), 26-29.

Fernández, E. C. G. (Ed.). (2016). Historia del cine. Fragua.

Fernández, J. A. (2019). Historia técnica del cine: Filmo de Bell \& Howell 100 años de una clásica. Cameraman: Revista técnica cinematográfica, (101), 42-49.

Figueroa, O. (2005). Transporte urbano y globalización: Políticas y efectos en América Freud, S. (2017). El malestar en la cultura (Vol. 328). Ediciones Akal. 
Gallegos, W. L. A. (2011). Una reseña introductoria a la psicología del tránsito. REVISTA DE PSICOLOGÍA/Journal of Psychology, 13(1), 113-119.

Galtung, J. (2004). Violencia, guerra y su impacto. Sobre los efectos visibles e invisibles de la violencia, 5 .

García, Y., \& Robalino, D. (2018). Educación vial para niños: Educar para salvar vidas.

Garmendia, F. (2016, April). La violencia en el Perú 2015. Anales de la Facultad de Medicina (Vol. 77, No. 2, pp. 153-161). UNMSM. Facultad de Medicina.

Gómez, M. A. A. (2018). El vídeo como herramienta de aprendizaje. In Innovación docente en educación superior: buenas prácticas que nos inspiran (pp. 35-50). Pearson.

González, J. C. (2016). Fomento de la solución colaborativa de problemas utilizando actividades de robótica LEGO (Master's thesis, Universidad de La Sabana).

Gutiérrez, J. C. (2018). Estrategias para la motivación de los estudiantes con la metodología Lego Serious Play Juan Pablo Gutiérrez C. Revolución en la Formación y la Capacitación para el Siglo XXI, 362.

Hernández, L., \& Carmen, M. (2019). Guía práctica para distribuir un cortometraje de animación en festivales.

Knop, F., \& Domínguez, A. K. (2017). El diseño y las características del videojuego en los juguetes lúdicos.

La Republica. $73 \%$ de intersecciones con semáforos no usa el sistema inteligente. 26 de Noviembre de 2014. Disponible en: (último acceso: 26 de Diciembre de 2016). La Republica. $73 \%$ de intersecciones con semáforos no usa el sistema inteligente. 26 de Noviembre de 2014. Disponible en: (último acceso: 26 de Diciembre de 2016). Lacan, J. (1948). La agresividad en psicoanálisis. Escritos I, 107-127. 
Larrauri, E. (2007). Criminología crítica y violencia de género. Madrid: Trotta.

Latina. EURE (Santiago), 31(94), 41-53.

Manzini, E. (2018). Una Aproximación del Diseño Social desde la Innovación y el Servicio Social. Diseño y Creación Foro Académico Internacional, 509.

Maskrey, A., \& Romero, G. (1986). Urbanización y vulnerabilidad sísmica en Lima Metropolitana. In Urbanización y vulnerabilidad sísmica en Lima metropolitana. PREDES.

MAZA, J. C. (2002). EVALUACIÓN DEL PROCESO DE PRIVATIZACIÓN DE LAS EMPRESA DE SERVICIOS PÚBLICOS 1991-2000. Gestión en el Tercer Milenio, 9(5).

Moreno, A., Estefania, P., \& Valdiviezo Peralta, V. M. (2014). Estudio de impacto vial para escuelas en zonas urbanas de Lima Metropolitana.

Mozo Sánchez, J. «Capítulo 1: Teoría de flujo vehicular.» En Análisis de Capacidad y Nivel de Servicio de Segmentos Básicos de Autopistas, Segmentos Trenzados y Rampas de acuerdo al Manual de Capacidad de Carreteras HCM2000 aplicando MathCad. Disponible en: 2012.

Olmos Rojas, M. (2019). Branded Content. Estudio del caso Lego.

Organización Mundial de la Salud. (2002). Informe mundial sobre la violencia y la salud: resumen. Washington, D.C.: Organización Panamericana de la Salud, Oficina Regional para las Américas.

Ortiz Ortiz, F. (2019). Ventajas del uso de videos educativos como herramienta de enseñanza en nivel de educación básica. Atlante Cuadernos de Educación y Desarrollo, (marzo).

Osborne, R. (2009). Apuntes sobre violencia de género. Barcelona. 
Otín, C. C., de la Fuente, F. P., López, M. R., Risco, I. C., \& Gómez, S. P. (2013). Aula en bici: un proyecto longitudinal de intervención docente en Ed. Primaria. Retos: nuevas tendencias en educación física, deporte y recreación, (23), 5-9.

Pariona Quispe, J. La gestión de cobranza en la recaudación en el SAT de la Municipalidad distrital de San Martín de Porres, 2018.

Pelliccia, A. N. (2017). Fases de la preproducción y posterior promoción internacional de un cortometraje (Doctoral dissertation).

Perú 21. Identifican 242 puntos críticos de congestión vehicular en Lima. 21 de Septiembre de 2016. Disponible en: (último acceso: 15 de Diciembre de 2016).

Prieto, J. R. E. (2019). Metodología" Lego Serious Play", La Ingeniería de la Construcción como Juego para Capacitación de Equipos de Alto Rendimiento. FINGUACH. Revista de Investigación Científica y Tecnológica de la Facultad de Ingeniería de la Universidad Autónoma de Chihuahua, 6(19), 12-13.

Rabanal, C. R. (1996). La violencia de las horas: un estudio psicoanalítico sobre la violencia en el Perú. DE COYUNTURA, 289.

Ramírez, M. E. (2007). Órdenes de hierro: ensayos de psicoanálisis aplicado a lo social.

Rius, L. F. (2000). Roles de género y mujeres académicas. Revista de ciencias sociales, 43(88), 63-78.

Robotix. Disponible en: (último acceso: 20 de noviembre del 2019) recuperado de https://www.robotix.es/blog/historia-lego-education/

Rodríguez, A. (2009). Resiliencia. Revista Psicopedagogía, 26(80), 291-302.

Rojas, L. M., \& Llamosa, R. (2016). Procesos de liderazgo organizacional en arquitecturas empresariales. Revista UIS Ingenierías, 15(1), 53-60. 
Rojas, R., \& Zapata, A. (2013). ¿Desiguales desde siempre? Miradas históricas sobre la desigualdad. Lima.

Salazar, R., \& Acha, R. (2009). La vida sin combis: ¿cómo seria hoy el trafico si entre 1991 y 1992 no se permitía la importación de vehículos usados? Perú Económico, 32(10), 33-36.

Sánchez Noriega, J. L. (2018). Historia del Cine: teorías, estéticas, géneros (pp. 1-20). Alianza.

Sandoval, P. (2004). Educación, ciudadanía y violencia en el Perú: una lectura del informe de la CVR. Tarea, IEP.

Scolari, C. A. (2018). Las leyes de la interfaz: Diseño, ecología evolución, tecnología (Vol. 136). Editorial GEDISA.

Simbaña Santos, D. D. (2018). Procesos y manual para la elaboración de un cortometraje animado en stop motion (Bachelor's thesis, Quito: UCE).

SUTRAN. Texto único ordenado del reglamento nacional de tránsito - código de tránsito. Lima, Perú: Superintendencia de Transporte Terrestre de Personas, Carga y Mercancías, 2014. Van Dijk, T. A. (2019). Racismo y discurso en América Latina. Editorial Gedisa.

Vargas, E. G., \& Oviedo, C. P. V. (2017). LA PARTICIPACIÓN DEL DISEÑO GRÁFICO EN CORTOMETRAJES ANIMADOS CON LA TÉCNICA “STOP MOTION”. JÓVENES EN LA CIENCIA, 3(2), 1638-1642.

Vázquez, M. E. (2014). Herencia y testamento (H. Arendt y J. Derrida). Bollettino Filosofico, 27, 179-194.

Vela, A. R. (2019). Breve historia del cine. Ediciones Nowtilus SL.

Vélez, J. G. D. (2018, August). EL USO DEL VIDEO EDUCATIVO COMO HERRAMIENTA DIDÁCTICA COMPLEMENTARIA PARA EL DESARROLLO DE 
CONOCIMIENTOS PROCEDIMENTALES. In Encuentro Internacional de Educación en Ingeniería 2018.

Vicuña, A., Leonor, N., \& Rojas Campos, N. A. (2014). La jerga en los actores del transporte público de Lima Metropolitana.

Vílchez, José. Diseño y simulación de un sistema para adquisición de parámetros de tráfico en avenidas. Tesis, en proceso de sustentación, Lima: Pontificia Universidad Católica del Perú, 2017.

Villagómez, E. M. (2008). El proceso de privatización de las empresas de servicios públicos en el Perú durante el periodo 1991-2000. Un análisis crítico. In Actualidad de los servicios públicos en Iberoamérica (pp. 293-326). Instituto de Investigaciones Jurídicas.

Villamizar Acevedo, G., \& González Ambrosio, J. E. (2015). El lego serious play como herramienta para solucionar problemas sociales. Estudio con alumnos de administración de empresas.

Vivanco, R (2017) Diseño H una perspectiva cultural, interdisciplinaria y holística, en Catálogo BLA GRÁFICO (pp 8 -14) Universidad San Ignacio de Loyola.

Wieviorka, M. (2003). Diferencias culturales, racismo y democracia. Políticas de identidades y diferencias sociales en tiempos de globalización, FACES-UCV, Caracas.

Wong, P., \& Gutiérrez, C. (2010). Autorreporte de accidentes de tránsito en una encuesta nacional en la población urbana de Perú. Revista Peruana de Medicina Experimental y Salud Pública, 27, 170-178. 


\section{Anexos}

\section{ANEXO 1}

Resultados de la encuesta aplicada a personas que manejan

\section{Edad}
a. $58 \%$ es mayor de 41 años.
b. $16 \%$ tiene entre 15 y 25 años.
c. $14 \%$ tiene entre 31 y 40 años
d. $12 \%$ tiene entre 26 y 30 años

2. Sexo
a. $54 \%$ es hombre
b. $46 \%$ es mujer

3. Actividad a la que se dedican
a. $76 \%$ trabaja
b. $24 \%$ trabajan y estudian

4. ¿Cuenta con brevete?
a. $100 \%$ cuenta con uno

5. ¿Cuánto tiempo lleva manejando?
a. $62 \%$ más de 10 años
b. $18 \%$ entre 6 y 10 años
c. $14 \%$ entre 1 y 5 años
d. $6 \%$ menos de 1 año 
6. El vehículo es de uso
a. $100 \%$ particular

7. ¿Cuántas horas maneja al día?
a. $42 \%$ de 2 a 3 horas
b. $28 \%$ más de 3 horas
c. $16 \% 1$ a 2 horas
d. $14 \%$ menos de 1 hora

8. ¿Suele manejar respetando el reglamento de tránsito?
a. $84 \%$ respondió que sí
b. $16 \%$ respondió que a veces

9. ¿Cuál suele ser su reacción frente al tráfico pesado?
a. $90 \%$ respondió que es estresante
b. $10 \%$ respondió que le era indiferente

10. ¿Ha llegado a alterarse a causa del tráfico vehicular?
a. $76 \%$ sí
b. $24 \%$ no

11 ¿Considera que, al respetar el reglamento de tránsito, el tráfico podría ser un poco mas fluido y por lo tanto tener menos estrés que desemboque en violencia vial?
a. $94 \%$ sí
b. $2 \%$ no
c. $4 \%$ no sabría opinar

Entrevistas Personales a facilitadores de la metodología Lego Serious Play 


\section{ANEXO 2}

Nombre completo

\section{CARLOS FRANCISCO VALENZUELA MARTÍNEZ}

Título / Cargo

CONSULTOR, DOCENTE UNIVERSITARIO, TITULAR GERENTE EN

EUREKA - JUGANDO EN SERIO EIRL. FACILITADOR DE LA

METODOLOGÍA Y MATERIALES LEGO® SERIOUS PLAY®

1. ¿Qué es LEGO en líneas generales?

LEGO es una empresa danesa de juguetes. Su producto más conocido son los bloques de construcción pero también cuenta con una línea de productos preescolares, una línea de juguetes de robótica, entre otros. Además presta su marca a la cadena de parques temáticos Legoland.

2. ¿Qué es LEGO SERIOUS PLAY y cuándo surge?

Surge hace más de 15 años como una idea interna de la compañía LEGO con el fin de desarrollar la dirección y planes estratégicos, y descubrir el potencial humano en la organización. Para 2001 la primera versión de LEGO® SERIOUS PLAY® estuvo 
lista como una técnica de pensamiento, comunicación y solución de problemas para equipos.

3. ¿Para qué se suele usar LSP?

Lo uso en talleres o entrenamiento a todo nivel jerárquico. Lo uso para el desarrollo de equipos, coaching, desarrollo de competencias, para el modelado de negocios, con Design Thinking, y para la mejora de la experiencia de usuarios.

4. ¿Considera que el concepto LEGO puede ser una herramienta importante que permite abordar temas difíciles mediante la lúdica y construcción?

Definitivamente. La metodología te permite generar conversaciones, y a través de ellas lograr los objetivos del taller. Te permite abordar temas delicados ya que las discusiones son sobre los modelos construidos y no sobre las personas.

5. ¿En su calidad de experto cuando trabaja con jóvenes y adultos dinámicas con LSP los resultados son mejores que si trabajara con otras herramientas?

Sí, ya que no hay preguntas correctas o incorrectas, todo depende de la interpretación de los participantes. Además los materiales te permiten moldear una y otra vez las ideas. 


\section{ANEXO 3}

Nombre completo

\section{MARIELLA HAGUE PÉREZ}

\section{Título / Cargo}

CEO \& Founder PARADERO

Espacio de innovación: diseño, estrategia y mindset

1. ¿Qué es LEGO en líneas generales?

Para mí en líneas generales es un ladrillo usado libre y comercialmente para crear todo lo que deseemos, que ha sabido adaptarse al cambio y no se detiene en el mundo del entretenimiento y la imaginación.

2. ¿Qué es LEGO SERIOUS PLAY y cuándo surge?

LSP surge en los 90s cuando LEGO comienza a competir con plataformas como

Nintendo, PSP y en ese momento se da una oportunidad (que es lo que se ve cuando sientes que podrías estar saliendo del mercado) y su Director de Operaciones, con un consultor de McKinsey, comienza la búsqueda de soluciones con los diferentes equipos, sin embargo, se dieron cuenta que "no todos participaban", "siempre el que habla toma toda la atención y no todos están enfocados en lo que está pasando", "que no todos son escuchados" y mucho, mucho más. 
Comenzaron sus investigaciones para resolver esto y buscar respuestas a sus

problemas y en ese camino se encontraron el "constructivismo", "la conexión que existe entre las manos y el cerebro" exploraron mucho más y descubrieron que era un nuevo momento para las piezas, no solo para usarlas para diseñar una solución sino además como herramientas para otras industrias por su poder e impacto.

3. ¿Para qué se suele usar LSP?

Para todo en realidad, depende mucho de la experiencia del facilitador, LSP tiene una estructura rígida para algunos, pero muy flexible en aplicabilidad, trabajo en equipo, planeamiento estratégico, alineación de conceptos, resolución de conflictos, océanos azules, escenarios futuros y mucho mucho más ...

4. ¿Considera que el concepto LEGO puede ser una herramienta importante que permite abordar temas difíciles mediante la lúdica y construcción?

LSP: Sí. El LEGO es una pieza y juego el LPS como su nombre lo dice es un juego serio en donde el facilitador y su experiencia pueden permitirte a través de esta metodología ver mucho más allá, tener consciencia personal y grupal.

5. En su calidad de experto cuando trabaja con jóvenes y adultos dinámicos con LSP los resultados son mejores que si trabajara con otras herramientas? 
En realidad para jóvenes es un poco lenta en ocasiones si el grupo es muy grande, en adultos funciona mucho mejor. Ahora en el caso de jóvenes funciona muy bien para sesiones individuales.

La aplicación de LSP es un juego serio, sin embargo, LEGO como herramienta para prototipado, ideación, design thinking en los jóvenes es muy potente.

\section{ANEXO 4}

Nombre completo

\section{RENDO DOMINGO SALAZAR SÁNEZ}

Título / Cargo

Facilitador Certificado en la Metodología Lego Serious Play

6. ¿Qué es LEGO en líneas generales?

Lego nació en Dinamarca como una empresa de juguetes y es reconocida mundialmente por sus bloques de plástico que se pueden unir para armar variadas figuras y en diferentes tamaños.

La palabra lego proviene de la frase del danés "leg godt", la cual significa "juega bien”, el término fue creado en el año 1934, por el creador de la compañía Ole Kirk Christiansen.

Actualmente la empresa LEGO tiene tres fábricas principales: Billund en Dinamarca, Nyíregyháza en Hungría y Monterrey en México. El pueblecito de Billund es la 
principal y mayor fábrica de todas y también es donde se encuentra el parque temático Legoland.

7. ¿Qué es LEGO SERIOUS PLAY y cuándo surge?

Es una revolucionaria Metodología implementada por organizaciones multinacionales como la NASA, Silicon Valley, Google, Apple, Harvard, Netexplo Observatory, entre otras

Todo se inició cuando, a finales de los años noventa, ya que hubo un "boom” por las consolas de videojuegos que acaparó la atención de niños y afectó las ventas a LEGO y otras empresas fabricantes de juguetes.

En aquel entonces Kjeld Kirk Kristiansen era Presidente y CEO de LEGO y transfiere a Robert Rasmussen de la división de LEGO Education a un proyecto de investigación donde estos juguetes podrían apoyar las estrategias que la empresa tanto necesitaba para recuperar el "terreno perdido". De esta manera, luego de algunos meses de investigación Robert Rasmussen logra la implementación de los ladrillos LEGO en una Metodología que nombran LEGO Serious Play.

8. ¿Para qué se suele usar LSP?

Para que a través de la construcción de ladrillos y la narración metafórica invite a los participantes reflexionar acerca de problemas que habitualmente no reconocemos y con ello se planteen estrategias de resolución de problemas. Se suele usar en distintas áreas como: 
- Estrategia Comercial, de Operaciones, RR.HH, Gestión del Talento. Selección de personas, Perfiles de Alto Potencial.

- Assessment Center, Evaluación de Jóvenes Profesionales y Construcción de Plan de Carrera.

- ADN de Marcas. Construcción de Identidad en temas diversos.

- Análisis y alternativas de solución de problemas complejos

- Integración de equipos multidisciplinares.

- Formación de Evaluadores y Facilitadores de procesos diversos.

- Análisis de Riesgos de Proyectos.

- Diagnóstico de situaciones y problemas en equipos de trabajo.

- Implantación de modelos de Gestión del cambio.

- Construcción de Escenarios de Futuro.

- Desarrollo de modelos de innovación, etc.

9. ¿Considera que el concepto LEGO puede ser una herramienta importante que permite abordar temas difíciles mediante la lúdica y construcción?

Tanto el concepto Lego Serious Play como el Juego Serio, pues como su nombre lo indica es un juego con propósito y ayuda a las personas a reconocer los problemas que no vemos en el día a día. Cualquier tema, por difícil que se considere, puede trabajarse en un Workshop con la Metodología Lego Serious Play, pues a través del juego se potencia la creatividad, el trabajo colaborativo, la comunicación, la empatía, 
etc. lo lúdico es solo el punto de partida de una ruta reveladora con situaciones que invitan a la reflexión y a plantearse estrategias para lograr nuevos resultados.

10. En su calidad de experto cuando trabaja con jóvenes y adultos dinámicos con LSP los resultados son mejores que si trabajara con otras herramientas?

Considero que sí. He tenido grandes resultados trabajando Talleres con jóvenes y

adultos. La experiencia LSP no solo es reveladora, sino que enriquece al autoconocimiento, a los participantes y sobre todo al logro de resultados de manera poco tradicional. Trabajar en educación me invita a buscar nuevas formas de conectar con los alumnos para que aprendan haciendo ... que construyan su propio conocimiento. 
Juicio de pares

Lima 19 de junio de 2020

Señores,

Escuela de Posgrado

Universidad San Ignacio de Loyola

Por medio de la presente me dirijo a ustedes a fin de poder dar una opinión objetiva respecto al proyecto de diseño para la tesis titulado EL VIDEO INTERACTIVO COMO HERRAMIENTA EDUCATIVA PARA PROMOVER EL CUMPLIMIENTO DEL REGLAMENTO DE TRÁNSITO Y PROPICIAR LA NO VIOLENCIA VIAL diseñado por el Bachiller Enrique Mauricio Jesús Vargas Vivanco referido a que existe un problema muy complejo y grave que es la violencia vial demostrando que pequeñas acciones como el desconocimiento de las reglas más básicas del reglamento de tránsito pueden desencadenar violencia incontrolable y accidentes fatales. A través del diseño de un video utilizando piezas de LEGO se puede lograr despertar conciencia sobre este problema y trabajar de manera preventiva-

Por lo tanto, al analizar y revisar el proyecto minuciosamente encuentro que el mismo es importante, porque en lo personal, en mi experiencia como visitante a la Ciudad de Lima, he visto y experimentado la falta de conciencia vial de los limeños. Creo que una campaña adecuada, dirigida a los jóvenes que no tienen el arraigo de esas prácticas viales, puede cambiar la forma de conducir en la ciudad, y puede crear y despertar esa conciencia que se necesita para el buen comportamiento vial.

Atentamente

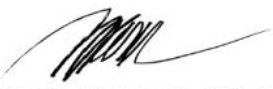

María Eugenia Cázares, MFA, MA

Escuela de Diseño

Universidad de Monterrey 
Juicio de pares

Lima 19 de junio de 2020

Señores,

Escuela de Posgrado

Universidad San Ignacio de Loyola

Por medio de la presente me dirijo a ustedes a fin de poder dar una opinión objetiva respecto al proyecto de diseño para la tesis titulado EL VIDEO INTERACTIVO COMO HERRAMIENTA EDUCATIVA PARA PROMOVER EL CUMPLIMIENTO DEL REGLAMENTO DE TRÁNSITO Y PROPICIAR LA NO VIOLENCIA VIAL diseñado por el Bachiller Enrique Mauricio Jesús Vargas Vivanco referido a que existe un problema muy complejo y grave que es la violencia vial demostrando que pequeñas acciones como el desconocimiento de las reglas más básicas del reglamento de tránsito pueden desencadenar violencia incontrolable y accidentes fatales. A través del diseño de un video utilizando piezas de LEGO se puede lograr despertar conciencia sobre este problema y trabajar de manera preventiva-

Por lo tanto, al analizar y revisar el proyecto EDUCAR, encuentro que el mismo es pertinente y necesario. Se trata de una propuesta lúdica muy acorde con su público objetivo y que busca generar conciencia en los jóvenes usuarios de automóviles para reflexionar sobre importancia de conocer y respetar las leyes de tránsito y adoptar una actitud más empática al conducir, reduciendo así el caos vehicular y los niveles de agresión vial.

EDUCAR busca a través de animaciones stop-motion presentadas en Instagram, que los jóvenes conozcan las reglas de tránsito y tengan una actitud empática para propiciar la no violencia vial. Considero que es un buen proyecto a nivel de maestría.

Atentamente

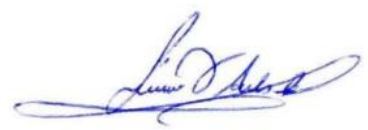

Mg. Guillermina Avalos C 


\section{Juicio de pares}

Lima 20 de junio de 2020

Señores,

Escuela de Posgrado

Universidad San Ignacio de Loyola

Por medio de la presente me dirijo a ustedes a fin de poder dar una opinión objetiva respecto al proyecto de diseño para la tesis titulado EL VIDEO INTERACTIVO COMO HERRAMIENTA EDUCATIVA PARA PROMOVER EL CUMPLIMIENTO DEL REGLAMENTO DE TRÁNSITO Y PROPICIAR LA NO VIOLENCIA VIAL diseñado por el Bachiller Enrique Mauricio Jesús Vargas Vivanco referido a que existe un problema muy complejo y grave que es la violencia vial demostrando que pequeñas acciones como el desconocimiento de las reglas más básicas del reglamento de tránsito pueden desencadenar violencia incontrolable y accidentes fatales. A través del diseño de un video utilizando piezas de LEGO se puede lograr despertar conciencia sobre este problema y trabajar de manera preventiva.

Por lo tanto, al analizar y revisar el proyecto minuciosamente encuentro que el mismo es importante y oportuno ya que este trabajo, mediante la línea investigativa en la que se centra, nos muestra la importancia de generar conciencia en lo referente al conocimiento de las reglas de tránsito y a la necesidad que tiene el conductor de cambiar de actitud a la hora conducir, ya que con ello se podrá mejorar tanto el caos vehicular como la violencia vial.

Las campañas propuestas por el autor de este trabajo, nacen desde el diseño gráfico, demostrando la importancia que tiene esta disciplina de las ciencias sociales en la búsqueda y contribución de soluciones a los diferentes tipos de conflictos que se dan en la sociedad. Este tipo de campañas están orientadas a jóvenes entre 18 a 22 años y personas que recién van a tramitar el permiso de conducir.

Es por todo lo expuesto, añadiendo la originalidad de la campaña al utilizar piezas de LEGO, que doy un informe favorable de esta tesis ya que cumple con todos los estándares académicos requeridos.

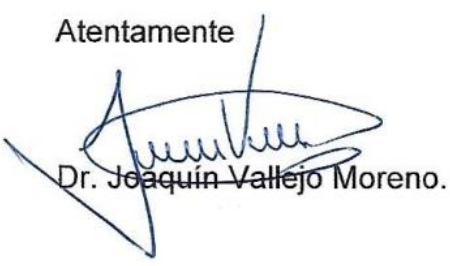




\section{Juicio de pares}

Lima 19 de junio de 2020

Señores,

Escuela de Posgrado

Universidad San Ignacio de Loyola

Por medio de la presente me dirijo a ustedes a fin de poder dar una opinión objetiva respecto al proyecto de diseño para la tesis titulado EL VIDEO INTERACTIVO COMO HERRAMIENTA EDUCATIVA PARA PROMOVER EL CUMPLIMIENTO DEL REGLAMENTO DE TRÁNSITO Y PROPICIAR LA NO VIOLENCIA VIAL diseñado por el Bachiller Enrique Mauricio Jesús Vargas Vivanco referido a que existe un problema muy complejo y grave que es la violencia vial demostrando que pequeñas acciones como el desconocimiento de las reglas más básicas del reglamento de tránsito pueden desencadenar violencia incontrolable y accidentes fatales. A través del diseño de un video utilizando piezas de LEGO se puede lograr despertar conciencia sobre este problema y trabajar de manera preventiva-

Por lo tanto, al analizar y revisar el proyecto minuciosamente encuentro que el mismo es importante y pertinente. Es un problema actual y me parece correcto trabajar con un público objetivo joven. -De igual forma la propuesta de solución resulta muy interesante, los videos son claros, atractivos y concretos. Considero serán de interés para el público considerado. Además considero pertinentes las variables y los instrumentos de recolección de datos, doy fe de que son adecuaros y que cumplen con los tres objetivos: confiabilidad, validez y objetividad,

Atentamente,

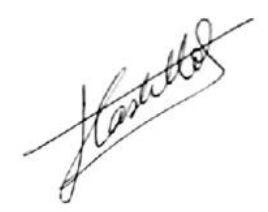

Mg.Fernando Andrés Castillo Sologuren 


\section{Juicio de pares}

Puebla, Puebla, MÉXICO, 21 de junio de 2020

Señores,

Escuela de Posgrado

Universidad San Ignacio de Loyola

Por medio de la presente me dirijo a ustedes a fin de poder dar una opinión objetiva respecto al proyecto de diseño para la tesis titulado EL VIDEO INTERACTIVO COMO HERRAMIENTA EDUCATIVA PARA PROMOVER EL CUMPLIMIENTO DEL REGLAMENTO DE TRÁNSITO Y PROPICIAR LA NO VIOLENCIA VIAL diseñado por el Bachiller Enrique Mauricio Jesús Vargas Vivanco referido a que existe un problema muy complejo y grave que es la violencia vial demostrando que pequeñas acciones como el desconocimiento de las reglas más básicas del reglamento de tránsito pueden desencadenar violencia incontrolable y accidentes fatales. A través del diseño de un video utilizando piezas de LEGO se puede lograr despertar conciencia sobre este problema y trabajar de manera preventiva-

Por lo tanto, al analizar y revisar el proyecto minuciosamente encuentro que el mismo es importante, pues se tienen que buscar las vías de comunicación idóneas para que los jóvenes que han vivido diariamente el caos vehicular, aprendan de una manera efectiva y lúdica sobre el cómo abordar el uso de las medidas planteadas por las autoridades para reducir el índice de accidentes viales que constantemente se presentan. Este proyecto se hace interesante y necesario pues, está utilizando las características idóneas del uso del lenguaje, tanto el visual, el hablado y el dinámico. Se hacen presentes los tres niveles narrativos de la comunicación: lo anecdótico (con el uso de historias reales, vivenciales que se muestran en las imágenes que los cortos y videos presentan y se acompañan con la narración hablada), lo metafórico (el representar al todo con la parte, el sustituir con figuras y ambientes LEGO las situaciones de la vida cotidiana -además que se utiliza un lenguaje gráfico asequible y accesible para los jóvenes a quienes está dirigido el proyecto-) y lo simbólico (donde a través de escenas y representaciones muy particulares muestra sensaciones y emociones que definen la universalidad del proyecto como el dolor, la angustia, el enojo, la molestia, la agresión que se provoca por el mal uso de las normas viales); pero el proyecto se vuelve trascendente pues al tener el objetivo de presentarse en las redes sociales no sólo ataca los problemas viales y de tráfico que se pueden presentar en la ciudad de Lima, Perú, sino que, debido a la trascendencia y potencial de las redes sociales, estos videos y cortos, además de las stories y los post digitales, llegarán a los jóvenes de diferentes países pues el mensaje que se evoca es universal -de ahí el carácter simbólico- y aparte en su conformación y estructura comunicacional se vuelve verídico, directo y 
concreto. Para que un proyecto de diseño sea efectivo y profesionalmente funcional se deben cumplir -además de muchos otros valores- tres aspectos importantes y creo firmemente que este en particular los cumple de manera satisfactoria: lo creativo (esto tiene que ver con la originalidad y la novedad, así como con la aplicación efectiva de la idea o concepto y en este proyecto existen estos elementos debidamente relacionados uno con otro), lo comunicativo (esto tiene que ver con la funcionalidad y efectividad del mensaje que se quiere emitir y aquí hay concreción, hay datos duros reales, existe un guión bien estructurado en la parte hablada, en la escrita y en el uso de las imágenes animadas a través del stop motion) y lo perceptivo (que tiene que ver con la estructura y la composición de los elementos del diseño, y en este proyecto hay una buena construcción de los ambientes, las figuras, las formas, los colores, la tipografía escrita y hablada, la composición de los elementos y la buena elección del uso de las figuras LEGO como medio de transmisión de mensajes, se notan horas de trabajo en el desarrollo de los videos para que se estructuren como un video en corto animado, existe pues una excelente organicidad de los elementos gráficos visuales que componen este proyecto.)

Es por esto que no tengo objeción alguna en recomendar ampliamente este proyecto pues aporta un claro mensaje, tiene un buen objetivo marcado, veo condiciones de trascendencia regional, nacional e internacional ya que despierta conciencia, trata temas actuales y utiliza un lenguaje y vías de comunicación contemporáneas y eficaces que atacan la sensibilidad, la emotividad de las personas y provocan el uso del ejercicio crítico, es por ello que me parece una excelente oportunidad de enviar mensajes de situaciones cotidianas problemáticas de una manera concreta y efectiva con la elección de las figuras Lego y la producción del video animado.

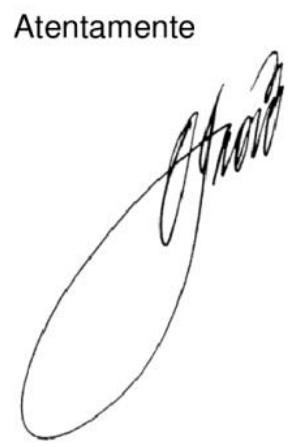

Mg. Osvaldo López Gaona 


\section{Juicio de pares}

Lima 19 de junio de 2020

Señores,

Escuela de Posgrado

Universidad San Ignacio de Loyola

Por medio de la presente me dirijo a ustedes a fin de poder dar una opinión objetiva respecto al proyecto de diseño para la tesis titulado EL VIDEO INTERACTIVO COMO HERRAMIENTA EDUCATIVA PARA PROMOVER EL CUMPLIMIENTO DEL REGLAMENTO DE TRÁNSITO Y PROPICIAR LA NO VIOLENCIA VIAL diseñado por el Bachiller Enrique Mauricio Jesús Vargas Vivanco referido a que existe un problema muy complejo y grave que es la violencia vial demostrando que pequeñas acciones como el desconocimiento de las reglas más básicas del reglamento de tránsito pueden desencadenar violencia incontrolable y accidentes fatales. A través del diseño de un video utilizando piezas de LEGO se puede lograr despertar conciencia sobre este problema y trabajar de manera preventiva-

Por lo tanto, al analizar y revisar el proyecto minuciosamente encuentro que el mismo es importante, pertinente y es necesaria su implementación, debido a que es necesario despertar la consciencia de la población acerca de las prácticas adecuadas de la educación vial tanto a nivel de peatones como de conductores. Es en este sentido que los videos presentados como parte fundamental del proyecto logran transmitir de manera didáctica, entretenida y sencilla el mensaje que dicta la norma acerca de las reglas de tránsito. Además, lo hace de una forma lúdica y con un lenguaje minimalista y familiar como lo son las piezas de lego. De manejarse con un adecuado plan de marketing y difusión en redes logrará tener la penetración adecuada para lograr calar en la memoria colectiva de la población que ahora recibe la mayoría de sus mensajes a través de las redes sociales. Es por ello que se considera al proyecto en cuestión como un adecuado, creativo y lúcido esfuerzo para buscar la concientización de la población peruana en general con respecto a un tema tan sensible - y que cuenta actualmente con un alto índice de estadísticas fatales. Por lo mencionado anteriormente, considero de vital importancia su implementación.

Atentamente

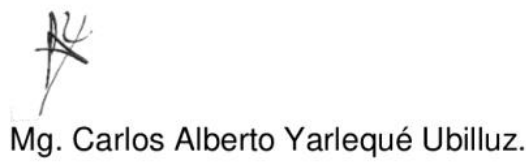

